Historic, Archive Document

Do not assume content reflects current scientific knowledge, policies, or practices. 




\section{To the Public}

E take pleasure in presenting herewith a carefully revised edition of our Descriptive Catalogue. We have taken great pains in the revision of our list to cull out all worthless varieties, and to catalogue only such varieties as we consider of special merit.

We are constantly on the watch for new things, both in the fruit and ornamental line, and we are adding such to our list as fast as their behavior proves beyond reasonable doubt that they are of value, and we believe the list which follows contains, with but few exceptions, all the fruit and ornamental trees, plants and shrubs which are of value throughout the Northwest.

LOCATION.-Our grounds are located on the open prairie land where the winds have an unbroken sweep for twenty or twenty-five miles from the northwest, and stock which is sent out by us has been thoroughly tested by as severe exposure as they are likely to meet when given their permanent planting.

PURITY OF STOCK.- - We take every precaution to keep our stock free from mixture, and we are very careful that everything we send out shall be true to name. If, however, by any error the stock received should be found to be untrue to name, we stand ready to replace such stock free of charge.

PACKING.-Our packing and shipping facilities are unsurpassed. We have a band of trained men, many of whom have been in the nursery business nearly all of their mature years, and we believe we are as well prepared to handle stock in a firstclass manner as any firm in the United States.

We take great pains in our packing, using only the very best of materials. Our packing-houses are large, covering approximately one and one-half acres, and all our packing is done under cover where the stock is not exposed to the sun and wind, and we can promise our patrons that the stock will be put into the hands of the railroad companies here in prime condition.

ERRORS.-We shall take every pains to get the goods to our customers in the best condition, and we believe few firms fail in this respect as seldom as we. If on the arrival of the goods any mistake should be found in the filling of the order, our patrons are requested to notify us at once, and, if possible, return the shipping tag which accompanied the goods with such notification, and all errors will cheerfully be made right.

SHIPPING SEASON.-Our shipping season usually opens in this section about the Ist of April and continues until some time in the month of May, and in the fall our shipments are made during the month of October and the early part of November. Please bear in mind that the planting season is not regulated by the day of the month nor by the state of vegetation where the planting is to be done, but the proper season for planting trees should be determined by the condition of the trees to be planted. It is better that these trees be started a little. Trees that have burst their buds will do better than those planted when perfectly dormant. It matters but little if the trees in the locality where the stock is being set are in full leaf if the trees that are being planted are not started to any great extent; they will be none the worse for having been planted a little late. As a rule, we have found that deciduous trees, as well as evergreens, do better if planted after the ground has begun to warm up. Frequently the time for planting corn is the best time for planting trees.

\section{Hints on Transplanting, Etc.}

We cannot attempt to give complete directions on all points connected with treeplanting, but simply a few hints on the more important operations. Every man who purchases a bill of trees should put himself in possession of some treatise on tree culture, that will furnish him with full and reliable instructions on the routine of management. Transplanting is to be considered under the following heads:

Ist. Selection of Orchard Site.- The best site for an orchard is on high land with a north or northeasterly exposure; such locations are usually found best, for the reasons that high land is not as subject to frost in blossoming season, and northerly 
exposures are not so subject as others to the freezing and thawing of ground in early spring, ground thaws a little slower, and as a consequence, trees do not start quite so early.

2d. The Preparation of the Soil.-For fruit trees the soil should be dry, either naturally or made so by thorough drainage, as they will not live or thrive on a soil constantly saturated with stagnant moisture. It should also be well prepared. On new, fresh lands, manuring will be unnecessary; but on lands exhausted by cropping, fertilizers must be applied, either by turning in heavy crops of clover, or well-decomposed manure or compost. To ensure a good growth of fruit trees, land should be in as good condition as for a crop of corn or potatoes.

3d. The Preparation of the Trees.-There are more fatal errors committed in regard to this important operation than in any other. As a general thing, trees are planted in the ground precisely as they are sent from the nursery. In removing a tree, no matter how carefully it may be done, portions of the roots are broken and destroyed, and consequently the balance that existed in the structure of the tree is deranged. This must be restored by a proper pruning, adapted to the size, form and condition of the tree.

4th. Planting.-Dig holes in the first place large enough to permit the roots of the tree to spread out in their natural position, thus having the tree pruned as before directed; let one person hold the tree, placing the heavier portion of the top to the southwest, and with the trunk slanting a little in that direction, while the other shovels in fine dirt about the roots, taking pains to fill all interstices, and bringing every root in contact with the soil. When the hole is nearly filled, if the ground is dry, it is a good plan to apply a pail of water to moisten the ground and wash the dirt in about the roots. This is unnecessary, however, if the ground is fairly moist. In this latitude, and especially north and west of here in dry lands, it is good practice to plant fruit trees about 6 inches deeper in the ground than they stood in the nursery row, but where land is inclined to be wet, they should be planted about the same depth as they stood in nursery. In dry, gravelly ground, the hole should be dug about twice the usual size and depth, and filled with rich, loamy soil.

5th. If trees are large and planted in exposed locations, they should be staked, and, if this is found necessary, the trunk should be wrapped with something to keep the stake from chafing the tree.

6th. Cultivation and Mulching.-When trees are planted, keep the orchard well cultivated up to about July I to Io, and for this purpose there is no better practice than to grow a crop of corn in the orchard, leaving the stalks to stand for winter protection; but where this is not practicable, cultivate the land to above date and then sow to some cover crop. Do not seed down an orchard so long as it can be avoided, but keep it cultivated as above indicated, and keep the soil well fertilized; but when the time comes that the orchard must be seeded down, sow to red clover and mulch the trees heavily so that grass will not grow within 6 or 8 feet of them. It is also good practice to spade up this mulched space about the tree each spring.

7th. Treatment of Trees Frozen in the Packages or Received During Freezing Weather.-Place the package in some cool place, a damp, cool cellar preferred, where the temperature is just a little above freezing, and allow it to remain there for several days until all frost is removed before opening the package. If stock is properly packed and handled as above directed, it will not be injured in the least by freezing.

8th. Directions for Wintering.-When trees are procured in the fall, select a dry place where water will be well drained off during the winter months; then dig a trench a little longer than the trees to be heeled-in, with the lower end about 2 feet deep. Dig the trench broad enough to contain the trees when spread in a single layer; then remove all packing material from about the trees and spread them out in the trench. When this is done, sift in fine dirt until all the open spaces are filled among the trees and roots and they are covered several inches deep, then tramp firmly and fill up the trench, mounding up the dirt so that the tops will be covered at least 4 inches deep and the roots about 2 feet. Care should be taken to remove all material from the trench and its vicinity which might serve as nests for mice.

Remarks. - We have not aimed in the above to give full directions for handling trees, but only a few of the main outlines. The above directions will also apply to the handling of pear, apricot, peach, nectarine, quince, plum, cherry, grape-vines, currant, gooseberry, mulberry, high-bush cranberry, Juneberry, weeping trees, shade and ornamental trees, shrubs, roses and vines. 


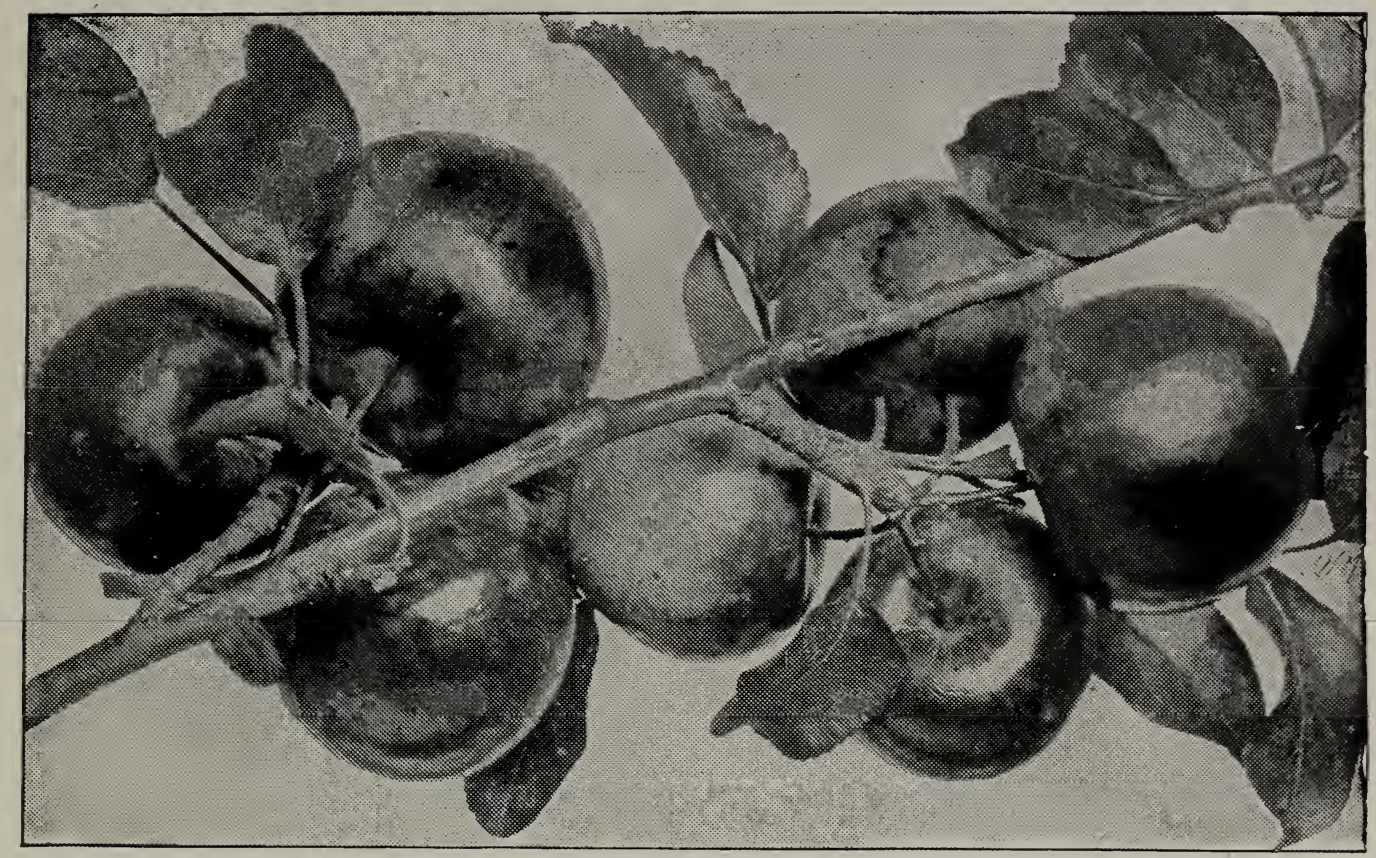

\section{Apples}

\section{SUMMER APPLES}

Charlimauff. A tree of German origin. Fruit large and strongly resembling the Duchess of Oldenburg, but more conical and of better flavor. Tree very hardy. Fruit ripens in August and September.

Duchess of Oldenburg. A large, beautiful Apple; roundish, streaked red and yellow; tender, juicy and pleasant. A kitchen Apple of best quality, and esteemed by many for dessert. Tree very hardy, a fair grower, and a young and abundant bearer. Season, August and September.

Summer Pear. Having stood a most severe test of over thirty-three years, always doing credit to itself, we take pleasure in offering this delicious Apple to our patrons. As hardy as the Duchess of Oldenburg; a heavy and early bearer; finegrained, with a distinct pear flavor. Without doubt the finest eating Apple of its season. No family orchard should be without it. Season, August.

Tetofsky. A slow, upright grower, with few branches. Tree one of the very hardiest; leaf very large and glossy; fruit yellow, somewhat splashed with red and covered with a white bloom; juicy, sprightly acid and ripens early in August.

Yellow Transparent. Tree introduced from Russia by the United States Department of Agriculture. A good grower and an annual bearer; hardy, but in some sections subject to blight. Fruit medium in size, roundish conical in form; skin smooth, transparent, surface clear white becoming pale yellow when matured; flesh white, tender, fine-grained, juicy and subacid. One of the best of our early summer Apples.

\section{FALL APPLES}

Fameuse, or Snow. A medium grower, rather spreading as an orchard tree; medium hardy, injuring badly in some sections, but has plenty of vitality, and will stand and bear many years after being badly injured. Fruit dark red, with flesh snow-white; one of the finest dessert Apples. Season, from November to January.

Gideon. This tree originated with Peter M. Gideon, of Excelsior, near St. Paul, Minn. It is a cross between the Blue Pearmain and our common crab-apple. Mr. Gideon says: "The tree seems to be as hardy with us as any of the crabs." Fruit medium to large, with blush on sunny side. Season, Nov. and Dec.

Iowa Beauty. A seedling of Golden Russett. Tree a strong, vigorous grower, very hardy, and more beautiful in form than Whitney No. 20. Fruit nearly white, splashed and striped with red. Season, September and October.

Longfield. Mr. I. S. Freeborn, of Richland county, Wisconsin, says:"It will 
FALL APPLES, continued

bear a bushel of Apples sooner than any tree that I ever planted." Medium hardy, fair size, red, blush on sunny side. One of the best of the Russians in quality. October to December.

Plumb's Cider. A variety introduced by J. C. Plumb, of Milton, Wisconsin. The tree came originally from Ohio, probably in I844. It is vigorous, an early bearer, and very productive in alternate years. The fruit is medium in size, rather oblong in form, greenish yellow splashed with light red. The flesh is greenish white, fine-grained, firm, juicy, subacid, of very good quality. On limestone lands this tree is regarded very highly through northern Iowa. Season, fall.

Wolf River. A large, showy red Apple of Wisconsin origin; a remarkably good market Apple in some sections, but not quite hardy in northern Iowa, except in favorable locations. Nov. and Dec.

\section{WINTER APPLES}

Arkansas Black. One of the most beautiful of Apples. It is a good keeper and commands a good price in market. The color is a lively red, deepening on the exposed side to purplish red or nearly black. Flesh decidedly tinged with yellow, very firm; rather fine-grained; crisp, moderately juicy, subacid; good to very good. Season, December to April or later.

Ben Davis. Large, smooth, often polished, nearly covered with red; subacid and one of the most profitable market Apples south. Tree vigorous, productive, and bears early.

Gano. Originated in Missouri. Similar but superior to Ben Davis. It has all the good qualities in a higher degree, more brilliant coloring, runs more even in size and keeps fully as late. The tree is vigorous and hardy; is a rapid grower; bears while young; color bright red, without stripes or blotches and large and even in size. February to March.

Golden Russett. Medium size; dull russet, with a tinge of red on the exposed side; flesh greenish, crisp, juicy and highly flavored; a slender grower, with light-colored speckled shoots, by which it is easily known; hardy, bears well, and is extensively grown in western New York and Wisconsin. November to April.

Grimes' Golden. Tree vigorous, upright spreading, and a good annual bearer. It is considered the standard of excellence throughout the West. Fruit medium size, regular, waxy golden yellow in color, flesh yellow, firm, compact, crisp, spicy, quality of the very best. Dec. to March.
Hibernal. (Russian.) Very hardy, rugged, spreading grower; fruit of large size, striped, quite acid; a good cooking Apple. Very valuable for the extreme North and for top-working to less hardy varieties. A winter Apple in the North.

Iowa Blush. Tree very productive, a strong grower in nursery and orchard. Fruit slightly roundish conical, yellow with bright mottled red blush, washed with bronze on the sunny side; flesh white, juicy, mild, subacid. Season, early winter.

Jonathan. Medium size; yellow, nearly covered with red; flesh tender, juicy and rich. A moderate grower; shoots lightcolored, slender and spreading; very productive; one of the best varieties for either table or market. This sort is too tender for the North, but much esteemed in the West, East and South. November to March.

McIntosh. This Apple is adapted to a wide range of localities, having been first raised in Canada, but now being successfully raised all over the north and northwest. The fruit is very attractive in appearance, of a bright deep red color, blotched and streaked with white and of good size. The flesh is very tender, perfumed and delicious. The tree is a vigorous grower and very hardy. Season, October to late winter.

McMahon. A very large, white winter Apple of Wisconsin origin. Tree a vigorous grower and very hardy.

Northwestern Greening. A strong, vigorous tree of Wisconsin origin. The tree bears young, and big crops of large, smooth, green Apples. The fruit is rather fine-grained, mild, subacid in flavor, and is a late-keeping winter Apple. It has been regarded by many of the horticulturists as not hardy enough for northern Iowa and Southern Minnesota, but in spite of this the tree seems to be standing our hard winters and bearing enormous crops of fruit that will sell as A No. I Apple in the best markets. The tree is very productive.

Okabena. Originated in southwestern Minnesota. Claimed to be a seedling of the Duchess, fertilized by the Wealthy. Tree an annual bearer of good fruit; hardy. Large; yellow, striped and splashed with red; flavor subacid; very good. Season, December.

Pewaukee. Origin, Pewaukee, Wisconsin. Raised from the seed of Oldenburg. Fruit medium to large, roundish oblate, skin bright yellow, striped and splashed with dark red; flesh white, tender, juicy, subacid. Tree vigorous. January to March. 


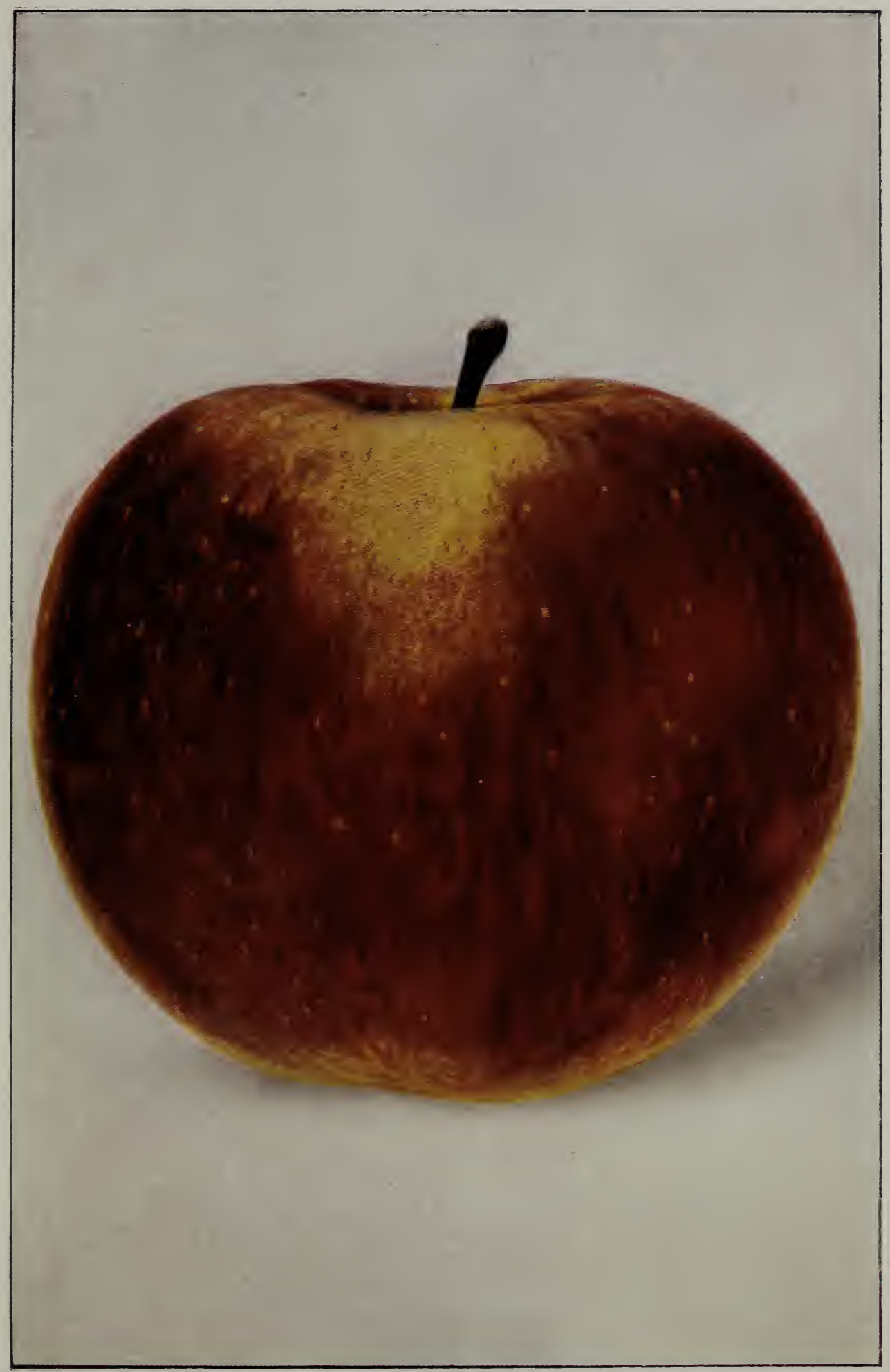

\section{EASTMAN}

An early winter apple of large size and attractive appearance. Though a seedling of Fameuse, it is much hardier. Fruit large, striped with red, with yellow dots; of an agreeable acid flavor, hangs well to the tree, which is hardy, vigorous and an early, constant and heavy bearer. Fills a profitable place in market, being at its best just after the eariy and before the late sorts. Season, October to December. 


\section{EASTMAN}

$\mathrm{W}$ HEN Apples are scarce, it doesn't make much difference what kind you have to sell.

But when everyone has Apples to sell, it makes a whole lot of difference.

In the fall of I9II, thousands of bushels of Apples rotted on the ground in Iowa. People said the reason was that "Apples were plenty." But that doesn't tell the story. While these thousands of bushels of fruit were going to decay in Iowa orchards, there were several varieties of Apples that were selling in the Minneapolis and Chicago markets for $\$ 3.50$ to $\$ 4.50$ a barrel.

At the top of the list of these Apples stood the Eastman, on account of its large and uniform size, attractive color and delicious quality. In direct competition with the best Apples the world produces, the EAstman stood the favorite.

The EAstman is a late fall Apple. The five reasons it is the favorite for commercial orchards are:

First. The fruit is large and uniform in size; there are no culls. No grading is necessary to put high-class fruit on the market.

Second. It has an attractive color. The color alone would seIl it in competition with most other sorts.

Third. While it is a late fall Apple it will, under ordinary conditions, keep fully a month longer than the Wealthy.

Fourth. Many Apple trees that would otherwise be profitable have the bad fault of dropping the fruit just as it is ripening. The Eastman Apples cling to the tree until they are picked.

Fifth. It has a delicious flavor, the memory of which easily induces the Apple-buyer to pay the top of the market for another taste. 


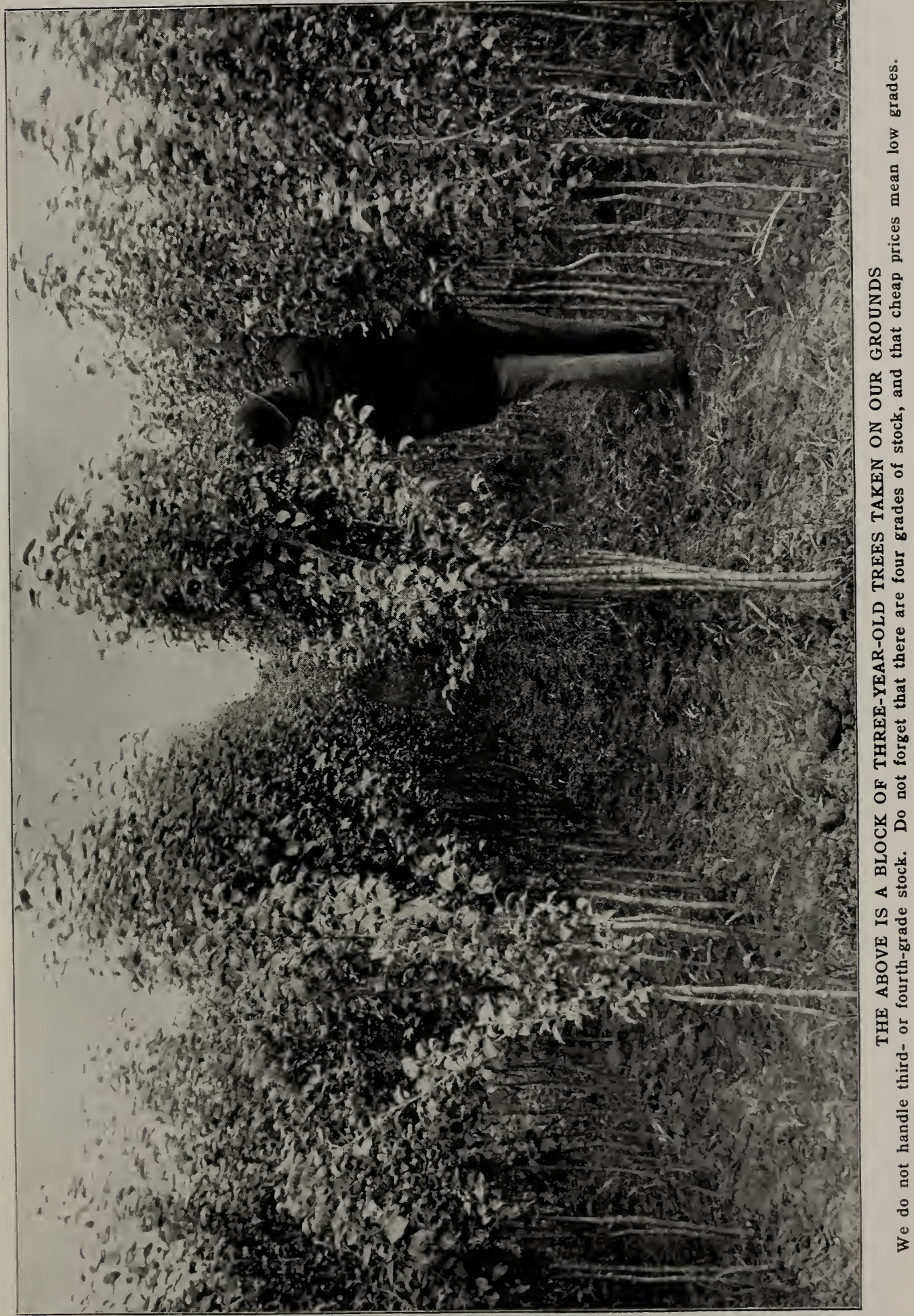




\section{WINTER APPLES, continued}

Rawle's Janet. Medium, roundish, ovate; greenish yellow, striped with red; crisp, rich and juicy. One of the best and longest keepers in the South and Southwest.

Roman Stem. A moderate-growing tree and one of the hardiest winter Apples of first quality that can be grown in this section. Fruit of medium size, whitish yellow, sprinkled with russet; flesh tender, juicy, rich; a very fine dessert Apple. Season, January to May.

Rome Beauty. Fruit of good size, uniform, fair, smooth and handsome; color yellow, striped and splashed with red. Stands handling remarkably well and is a good keeper. Has an established reputation in market and sells at good prices. Tree is a good orchard grower, attaining a good size. Flesh nearly white, firm, rather crisp, juicy and slightly aromatic. Season, November to May.

Salome. A vigorous, upright grower in the nursery; in the orchard it becomes large. Fruit uniform in size and shape. Flesh firm, crisp, tender and juicy. Season, November to March.

Scott's Winter. A tree of Vermont origin. A strong, upright grower and an annual bearer. This tree is considered promising at the North. Fruit rather small, oblate, yellow, mottled with red and russet; flesh yellow, fine-grained, juicy, crisp and pleasant; sprightly acid. Season, late winter.

Spitzenburg. Tree rather a slow grower. Fruit tinged with yellow; firm, moderately fine, crisp, rather tender, juicy and aromatic. Season, November to February.

Stayman's Winesap. The best variety of Winesap for general cultivation. The tree comes into bearing young and is a reliable annual cropper. Very attractive in appearance, being of a reddish cast with splotches of yellow. Fruit large and shapely. Flesh very juicy, pleasant subacid. Season, December to May.

Tallman Sweet. One of the hardiest sweet Apples; a good bearer. Fruit of medium size, light green and very sweet. An excellent baking Apple. Season, December to March.

University. Originated in I88I, a seedling of Perry Russett and as large as
Patten's Greening. A rich golden yellow when ripe. Has been highly recommended by leading horticulturists in Minnesota. Absolutely hardy; a young, constant and prolific bearer. Tree a beautiful spreading grower; one of the most magnificent of the Apple trees. October to January.

Wagener. Tree not a vigorous grower, but a fair bearer. An apple of superior excellence. Color a beautiful bright red with some contrasting pale yellow. Especially fine for dessert. Fruit rather large, roundish oblate in form. Flesh finegrained, tender and juicy. Season October to spring.

Walbridge. The worst fault with this tree is that it is a tardy bearer. When it arrives at bearing age it bears well and the fruit is highly prized, as it keeps late in the spring. Fruit medium size, subacid, striped with red and yellow. Season, March to May.

Wealthy. Originated near St. Paul, Minnesota. A vigorous-growing tree, very hardy and an abundant bearer. Fruit large, nearly red, subacid and of first quality. G. W. Wheaton, one of the oldest fruit-growers in northern Iowa, said of this tree that if he were to plant a market orchard of $\mathrm{I}, 000$ trees, he would plant 999 Wealthy, and when asked what the other would be, he said he would plant that Wealthy also. All things considered, it is a hard tree to beat. Season, early winter.

Winesap. An old variety, supposed to have originated in New Jersey. Tree moderately vigorous, with rather open spreading habit, very productive and an early bearer. Fruit rather above the medium size, conical in form, rich yellow color, mostly covered with fine lively dark red, sometimes slightly striped; flesh yellow, firm, fine-grained, rich subacid. This variety is very popular throughout the South and West, but is not hardy enough for this latitude, except in sheltered situations, where it is protected from extremes of weather. Season, December to May.

Winter Banana. Tree medium in size; vigorous. Fruit large to very large, not very uniform in size or shape. Very fine for dessert. Flesh whitish tinged with pale yellow; tender, juicy and very good. Season, November to April.

\section{NEW WINTER APPLES}

ANISIM. This, without doubt, is the most valuable of Russian Apples. Tree bears very young and regularly enormous crops of beautiful fruit; is hardy, free from blight, of good quality. Fruit roundish, medium size, color greenish yellow, covered almost wholly with a heavy dark crimson bloom, thickly dotted with minute white specks; flesh greenish white, with green veins; flavor subacid, pleasant. Season, early 
NEW WINTER APPLES, continued

winter. The Anisim is a variety which has, perhaps, been better known as "Good Peasant." The tree is wonderfully productive, and while the Russian Apples, as a class, we think have been overestimated, still there can hardly be too much said of this variety. The tree bears very young, and is very productive. In fact, few trees excel it in this particular, and the fruit is so beautiful in appearance that it would sell in any market regardless of quality. But, in addition to this, it is among the best in quality of any of the late fall and early winter Apples that can be raised in this latitude. A man can not err in buying this tree. Orchards of it will pay, and pay well.

EASTMAN. A seedling of the Fameuse, or Snow, decidedly more hardy than its parent, in fact, can favorably be compared with the Wealthy. It is now bearing I 50 miles north and south, and 300 miles east and west of here and in all cases has received the highest praise from those fruiting it.

As a market fruit, it fills a place where such an Apple is in great demand, namely, just after the early and just previous to the late ones. This magnificent Apple has been bringing \$I more per barrel on the Minneapolis market than the Wealthy, and we consider it one of the coming commercial varieties.

We are so confident of its success that we have planted more than five acres of them. Fruit large, fine colored, striped with red, hangs well to the tree; agreeably acid, and of fine quality; very young, constant and heavy bearer. An excellent dessert and cooking Apple; we unhesitatingly recommend it. Season, October to December.

IOWA BRILLIANT. Another seedling of the Fameuse, resembling its parent in many of its characteristics, having very white, tender flesh and, as its name implies, is a most brilliant red. Same size as Wealthy, and at this date (October 28), is still hanging to the tree. This fine variety has stood the test as far north as Minneapolis, Minn., and bears fine crops of splendid fruit, which keeps until March. Minneapolis fruit-buyers have offered $\$ 7$ per barrel for this Apple in car lots, when Talman Sweet, Grimes Golden and Greenings were selling on the market for $\$ 4.5 \circ$ per barrel. There is not an Apple on our testing list of over three hundred varieties which has the flavor, tenderness of flesh, color, and selling qualities of this Apple, and we recommend it as one of the very best. Season, January to May.

MALINDA. Tree originated from seed sown in northern Vermont. It is a moderategrowing, crooked, scrubby nursery tree, but does better in northern Iowa than almost any other late-keeping winter Apple. Tree is perfectly hardy here and bears extremely well; fruit about the same size and color as the old yellow Bellflower; flavor very mild acid; one of the very best baking Apples. Season, February to July.

Mr. JoHN Q. Richardson, of Elgin, Minn., says: "I have a Malinda tree on my place that has been planted thirty-five years. It survived the winter of 1873 , when the thermometer registered $52^{\circ}$ below zero, and has since withstood a temperature of $42^{\circ}$ below zero. This tree bore eight bushels of Apples last year. I have several times kept the fruit until the 4th of July, and have known it to keep as late as August $\mathrm{I}$. The Malinda bears young and well with us."

"I have two dozen Malinda trees growing in my orchard, and I prize them higher than any Apple $I$ have, for the reason that they are as hardy as Duchess and very prolific. My trees paid me over one hundred dollars last fall. They are the finest eating or cooking Apples I ever tasted. I can heartily recommend it to those wishing to plant an Apple tree that will be a lasting pleasure as well as profit."-A. K. BAYLEY, Platteville, Wis.

NEWELL'S WINTER. Originated in Wisconsin about 60 miles north of Madison. It is a seedling of the Perry Russet. The fruit is large, roundish oblate, and of a rich yellow color; flesh firm, juicy, yellowish, rich, sprightly and subacid. This Apple is one that will rate A No. I with any of the eastern Apples. It is a fruit that will keep all winter. Tree hardy and free from blight.

\section{$\underline{\text { Patten's Greening }}$}

This variety originated from seed of the Duchess of Oldenburg. As a nursery tree it grows very crooked, but makes a fine spreading orchard tree; it is a better bearer than the Duchess and quite as hardy; fruit about the same shape and much larger, but green in color; a fair eating and an excellent cooking Apple. Season, November to January:

We think this variety will bear more bushels of Apples in a given length of time than any other tree we know. The fruit is large and showy, brings better prices in the St. Paul market than any other fruit during its season. There cannot be too much 


\section{PATTEN'S GREENING APPLE, continued}

said for this variety. Remember it is the southern trees that grow straight. This is not a southern tree. The Patten's Greening, though vigorous and strong in its growth, is never straight, but it has been reported hardy by the keepers of the State Experimental Stations as far north as Manitoba. This variety originated with Mr. C. G. Patten, of this place, from the seed of the Duchess of Oldenburg. The tree is a tremendous bearer. No variety stands higher than this, or has had more good words said for it by the horticulturists of the Northwest.

The following are a few of the good words that have been spoken for the Patten's Greening.

I have taken much interest in watching the growth and fruiting of a seedling Apple originated at Charles City, and known as Patten's Greening. The tree at different stages, from blooming to fruiting, has been closely examined, and has never shown a trace of blight. I regard it as perfectly hardy-tough as bur oak. The tree is a good bearer of handsome, fair-flavored fruit of good size. As a cooking Apple it has no superior. It comes the nearest to a winter Apple of anything yet produced which will do well in northern Iowa, and I should no more hesitate to plant it than I would box, alders or soft maples as to hardiness and freedom from blight.--J. S. TRIGG, editor of the Rockford Register, Rockford, Iowa.

J. S. Harris, of La Crescent, Minn., says of the Patten's Greening: "This variety of Apple is now so well disseminated, and is doing so well in every locality where it has been tried, that I feel safe in recommending it. It is a seedling of the Duchess of Oldenburg, originated from seed planted at Charles City, Iowa, seed grown near Portage, Wis., in I869. The tree appears to have inherited the hardiness and fruitfulness of the mother parent, and has derived an improved flavor and keeping qualities from some other source. The original tree has produced fifteen crops of fruit. It is a somewhat stronger grower than the Oldenburg, has large, thick foliage, and the limbs are stronger shouldered, capable of resisting strong winds and sustaining a great weight of fruit. The variety is doing well in Iowa, Wisconsin, South Dakota, and wherever planted in Minnesota. The fruit is fair for eating from the hand, and is unsurpassed for cooking. Have kept this Apple through January and February."

Samuel B. Green, Professor of Horticulture in the University of Minnesota, says of Patten's Greening: "It is, perhaps, the most fully satisfactory tree in health, hardiness and bearing habit for this section of any on the list; keeps as long, or nearly as long, as Wealthy, and does well in cold storage. A variety that has proved to be very profitable in the home orchard, or for market, and deserves the fullest confidence of our planters."

Considering the size, quality and season of fruit, as also the pedigree and known hardiness of tree, it seems to me worthy of general planting in northern Iowa and adjacent territory.--C. L. Watrus, Des Moines, Iowa.

Mr. A. Peterson of Waconia, Minnesota, says: "I do not consider there is any place where the blight is as bad as on my grounds. All of the Russians blight badly, but the Patten's Greening is all right. It is hardy and a good bearer."

A crooked nursery tree, but one of the finest large Apples, and should be in every collection.-Geo. J. Kellogg \& Sons, Janesville, Wis.

The Patten's Greening is apparently as hardy as a forest tree. It is the coming winter Apple.-D. Cook, Vice President Minnesota State Horticultural Society, Windom, Minn.

J. A. Howard, of Hammond, Minnesota, has picked ten bushels of Apples from one tree of Patten's Greening that had been planted six years, and sixteen trees of this same planting averaged from five to six bushels per tree.

L. G. CluTE, of Greeley, Iowa, says: "I have I04 of the Patten's Greening in bearing. I will further state that last year they gave me more and better apples than all the other trees put together. I have over I,000 trees in bearing. This year is an off year, and the Patten's Greening is far ahead of all other varieties as far as fruit is concerned. I have trees nine years old that measure 22 inches in circumference and are 25 feet from tip to tip of limb. I had trees seven years old that picked eight bushels of apples; roo averaged over four bushels of apples per tree. The Patten's Greening is the very best tree in northern Iowa. Its commercial value is very great."

I have an orchard of near 2,000 trees, and more than roo varieties of Apples, and I consider the Patten's Greening among the best I have, if not the very best, considering the hardiness of tree and the fruitfulness thereof. I consider it safe for farmers to plant in Minnesota. If they cannot raise fruit from Patten's Greening, they had better give up the job.WM. SOMERVILLE.

PEERLESS. Tree originated in central Minnesota in 1864 or $186_{5}$. It is a strong, vigorous grower. Bark very dark. Apple very large, splashed and striped with dull red; of a pleasant subacid flavor. Ripens in late fall or early winter.

PETER. This variety was originated by Peter M. Gideon, Excelsior (near St. Paul), Minn. He says of it: "We take pleasure in calling attention of all lovers of fine fruit to what we consider the best Apple grown. Origin, Wealthy seed, and in form, size, and color an exact duplicate of the parent, but differing in flavor and sea- 


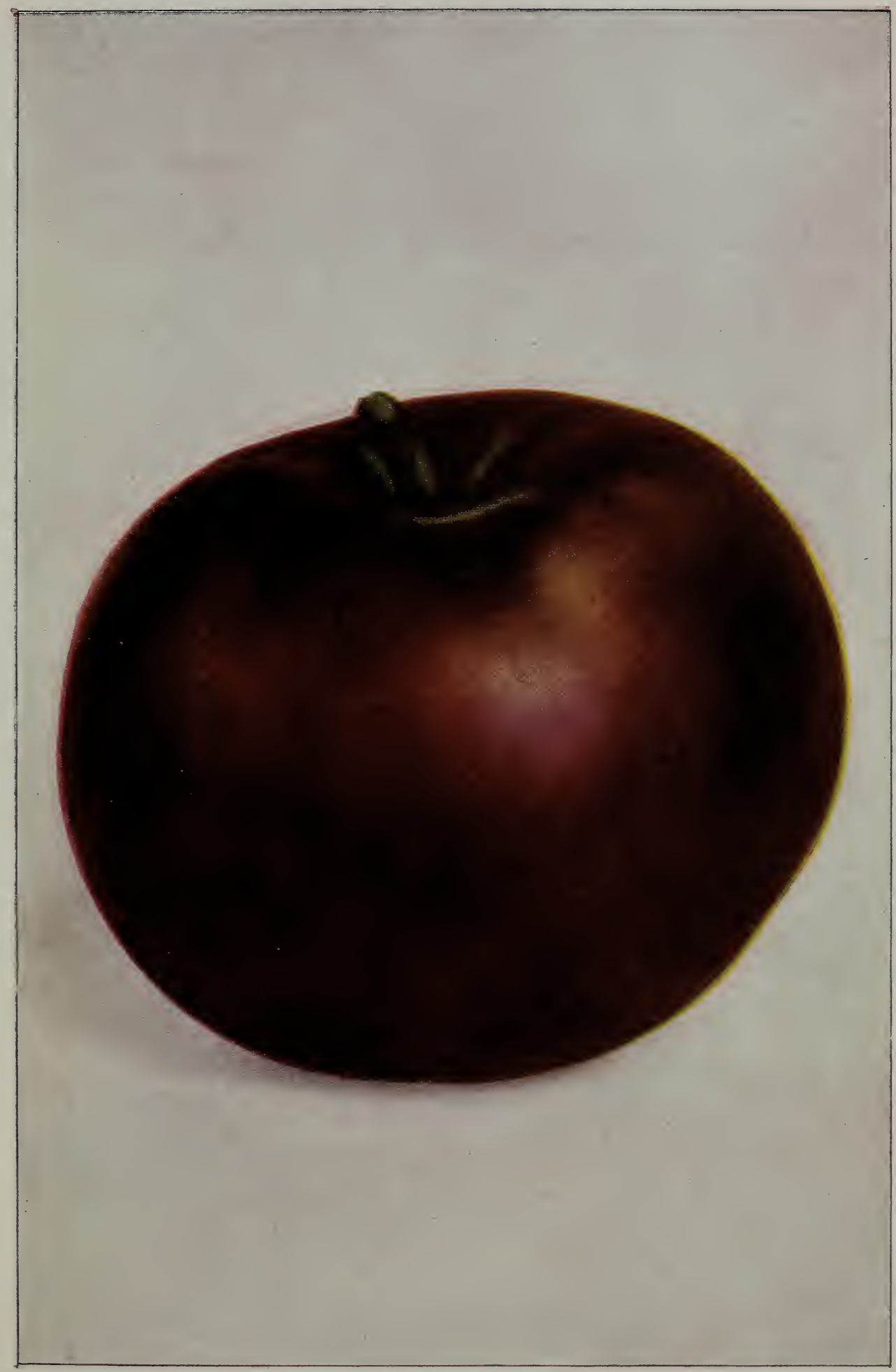

\section{IOWA BRILLIANT}

A Fameuse seedling of exceptional hardiness, beauty, flavor and keeping quality. The brilliant red fruit resembles McIntosh Red in color but is far superior in flavor. Fruit about size of Wealthy with fine-grained, white, tender flesh. Hangs late on tree, and keeps well through winter. Tree hardy and vigorous, and an abundant bearer. The high flavor and brilliant color have made it sell in market at unusual prices. Season, January to May. 


\section{IOWA BRILLIANT}

7 HE Apple is the King of Fruits; and, beyond question, the Brilliant is the King of Apples.

Everyone is familiar with the Wealthy, with its splendid color, its delightful flavor, its large size, its wonderful bearing qualities and hardiness. The Brilliant has all these and more.

It is equal to the Wealthy in size and bearing qualities. It is hardier in growth, more splendid in color, more delightfuI in flavor, the fruit hangs on the trees till picked and, best of alI, the Brilliant Apple Will Keep Over WINTER.

With ordinary care and under ordinary conditions the BriLliant has been kept not only through the winter, but until the middle of June, with its splendid color and flavor unimpaired.

Don't buy your Apples at the store. This red, juicy kind will grow in your own back yard. 


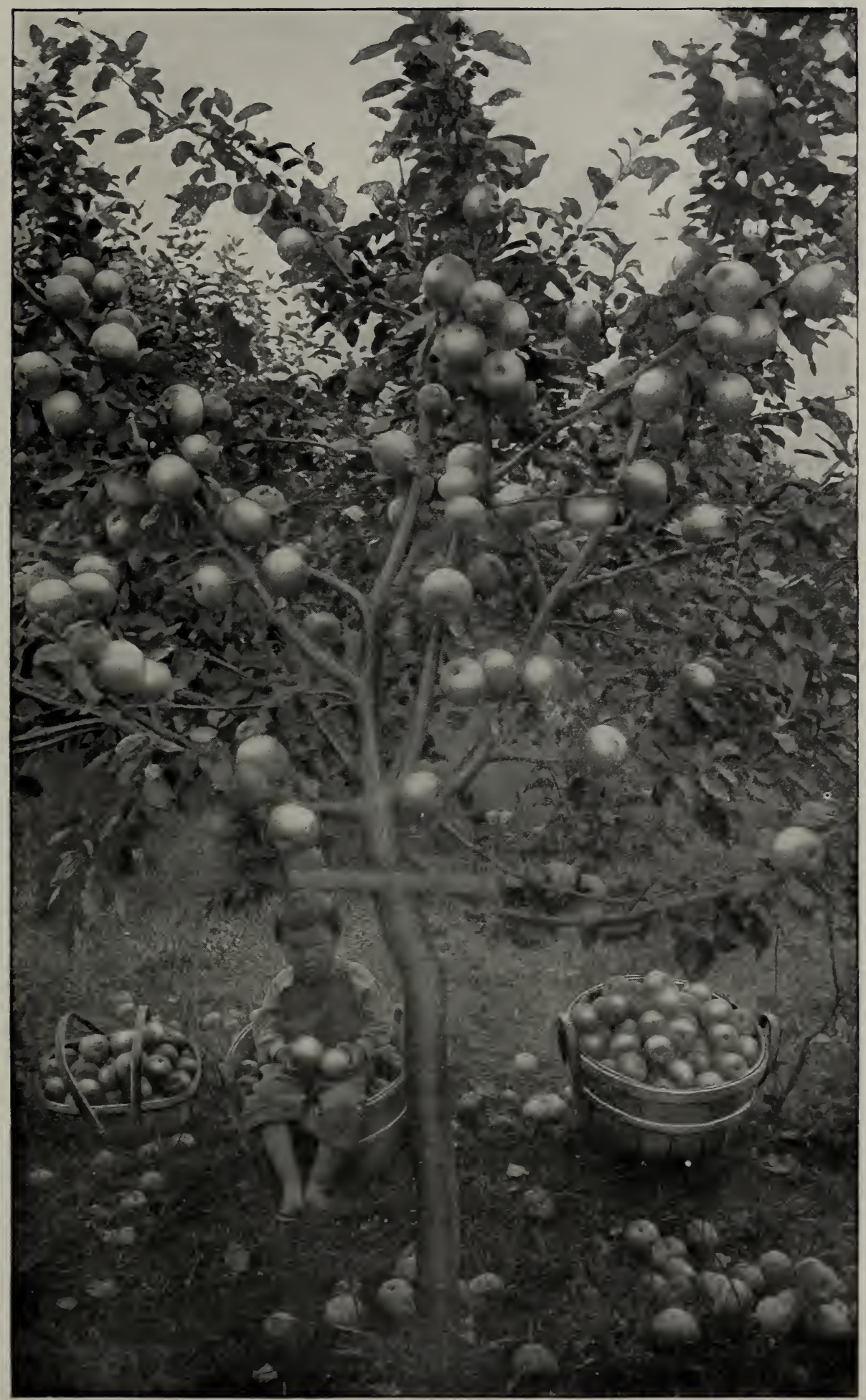

Photograph of a Patten Greening Apple Tree at Hammond, Minn., in orchard of J. A. Howard 


\section{PETER APPLE. continued}

son, keeping from four to six weeks longer. It is what, after tasting, Col. John $\mathrm{H}$. Stevens pronounced 'the best Apple ever introduced since Adam and Eve left the Garden of Eden.' The fruit adheres well to the tree, which is a little hardier than the Duchess and Wealthy. At the Iowa State Fair the Peter Apple was pronounced by the judges to be superior to the Wealthy in every respect. It appears to be one of the hardiest trees on our place." This variety, like all others of value in this section, originated in the Northwest. It has not been largely planted, for the reason that the fruit so closely resembles the Wealthy that many growers had considered it identical with it. The tree is more vigorous than the Wealthy, and while the fruit closely resembles it, still we consider it a better Apple. Mr. Gideon considered it superior to the Wealthy, and we believe that his estimate of it will prove true in the Northwest. We consider that there can not be too much good said of this variety.

\section{CRAB APPLES}

Briar Sweet. Fruit large, pale yellow, with carmine cheek, very sweet, good for preserving and best of all for sweet pickles. Tree vigorous and productive. September.

Florence. A seedling of the Duchess of Oldenburg. Tree rather slow, spreading grower; bears very young and profusely; when in full fruit, very ornamental; very hardy. Color light yellow, thickly splashed with bright red. About the same size and season as Transcendent.

Hyslop. A very late-keeping, dark red Crab of large size; tree an abundant bearer, vigorous grower and perfectly hardy. Season, November to April.

Minnesota. A very bushy growing tree, but free from blight and perfectly hardy. Fruit nearly as large as Fameuse, light yellowish green, with tinge of red on sunny side. Season, Nov. and Dec.

Soulard. This is a hybrid with our native wild Crab, Pyrus Coronaria, or

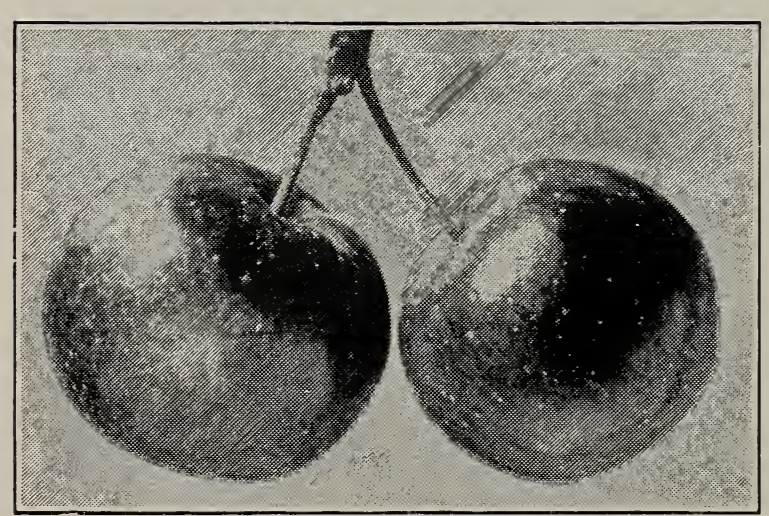

Hyslop Crab Apples possibly a sprout from the wild Crab. It is about the size of Fameuse or Snow Apple. Light yellowish green in color and keeps until spring. Its chief value is for preserves, and it is valued by many as highly as the quince for this purpose. The tree is a strong, vigorous grower, and very hardy. Bears well.

Strawberry. Fruit medium, highly colored, exceedingly tender, mild acid, fine eating or cooking; tree hardy, fine grower. Two weeks earlier than Whitney No. 20.

Sweet Russet. Very large hybrid; extremely hardy. Fruit oblong, conical, light russet, very rich and sweet. One of the best either for eating or cooking. August and September.

Transcendent. A vigorous grower and abundant bearer, but blights badly. Fruit medium size. Season, early August.

Virginia. Size of Transcendent; a month later; light red, sprightly, juicy, crisp. Great bearer; fine market sort. Valuable tree on which to topwork large Apples.

Whitney No. 20. A beautiful growing tree, and one which bears young and abundantly. Fruit of good size, conical in shape, red and yellow striped; flesh crisp, subacid, and very fine eating; no Crab taste whatever. It is really a small Apple and should be classed as such. Season, September.

Yellow Siberian. Tree a vigorous grower. Fruit small, conical-shaped, yellow. Ripens in September.

\section{A Few Facts with Regard to Orchard Returns. What These Men Have Done, You Can Do}

Mr. C. W. Levens, of Albert Lea, Minn., says that from an orchard of less than half an acre he sold a car-load of Apples in 1892 , for which he received $\$ 300$. He says the same trees produced over $\$ 200$ worth of Apples this last season.

The ten-acre orchard of Mr. Holly's, of Winnebago City, Minn., all of Wealthy Apple trets, and situated on the high, open prairie, he says produced 900 bushels of Apples in r 893 , 


\section{ORCHARD RETURNS, continued}

and he sold them on the trees for $\$ 900$, and the following season the same orchard produced over 700 bushels, and sold at 75 cents per bushel.

Three thousand five hundred bushels at $\mathrm{S}_{\mathrm{I}}$ a bushel were raised and sold by Mr. R. C. Keel, of Rochester, Minn., in one year.

Of fifty Duchess of Oldenburg planted in 1862 by Mr. Sommerville, of Viola, Minn., 49 are still living, healthy and sound. Mr. Sommerville says he has not had a failure in fruit for twenty-five years, and they have given him a larger net profit during that time than the best 40 acres of his farm.

Mr. Lord, of Minnesota City, Minn., says he has picked 53 bushels of plums in one season from 25 trees and sold them at $\$ 2.10$ a bushel, and has missed but two crops in 30 years. in 1894 .

Mr. Cook, of Cottonwood county, Minn., says he sold $\$ 60$ worth of plums from I 5 trees

In the fall of $\mathrm{I}_{90} 3$ Flias Long, of Stilson, Iowa, gathered 12 bushels of apples from four trees of Northwestern Greening purchased of us in 1897. Six of these apples placed side by side measured 20 inches, and ten of them weighed $61 / 2$ pounds.

Nine years ago we sold C. P. Warner, of Bassett, Iowa, two trees of Malinda from which he has this season (I903) gathered I 7 bushels of apples.

In 1902 C. G. Patten \& Son, of Charles City, Iowa, gathered 333 barrels of first-class apples from 293 trees of Duchess of Oldenburg, occupying a little less than three acres of land; they sold this crop for $\$ 2.10$ per barrel; from the same trees in I 903 they gathered 443 barrels of first-class fruit, which brought $\$ 2.65$ per barrel. They also tell us that from their orchard of Patten Greening, which had been planted six years in I903, they gathered on an average a little better than one barrel per tree, some yielding $1 \frac{1}{2}$ barrels per tree.

In the above statement no account has been made of windfalls and second-class fruit, which was gathered and disposed of at retail, and the prices named are those received for goods at wholesale delivered f. o. b. Charles City. You will notice by the above figures that their orchard of Duchess of Oldenburg is yielding them an annual income from $\$ 242$ to $\$ 382.50$ per acre.

\section{Do Orchards Pay?}

We have given above a few facts with regard to the profit of orcharding in this section, and these facts are given merely as suggestions. If you will investigate matters carefully in any neighborhood we believe you will be able to pick up information with regard to the yield of fruit that will surprise you. Visit the leading fruit-growers and ascertain from them what they have planted, when it was planted, and what they have been able to get in the way of crops. Usually you will be compelled to pick up this information in small items; frequently you can get at accurate figures with regard to the yields of perhaps but a few trees in a place, but from these you can quickly figure what the yield would have been on an orchard of Io acres, and the returns that could have been realized, figuring the crop at usual market prices. Such investigation, we believe, will readily convince any thoughtful person that there is far more profit in commercial orcharding in the North today than there is in any other use to which good lands can be put.

Beyond any question, there is good money today an a good commercial orchard in the Northwest. Where varieties are well chosen, planted in good soil, and given intelligent care, we believe a person can make dollars in Iowa or any of its adjoining states, raising apples or plums, to dimes that can be made in California raising oranges, lemons or prunes.

We urge you to plant a few varieties for this purpose. Four is a big plenty, and one or two is better still, for the reason that, when one has a large number of trees loaded with one variety, he will always find plenty of wholesale fruit dealers in the cities who will come to his place and buy the fruit in the orchard, paying the best market price, and giving him a sure and ready market; whereas, if many varieties are planted, one is confined to local markets and to a peddling trade, which is never satisfactory and often unprofitable.

Apples have been sold in the orchards here this season at prices ranging upward of $\$ 2.50$ per barrel in car lots, when the same varieties were begging for sale on the street in small lots at 25 cents per bushel.

\section{Apricot}

Alexis. Large to very large; yellow with red cheek; slightly acid, but rich and luscious. Tree hardy and abundant bearer. July i 5 .

Alexander. An immense bearer; fruit of large size, oblong, yellow, flecked with red, flavor sweet and delicious. Tree hardy. One of the best. July $\dot{I}$.

J. L. Budd. Of large size, white with red cheek; flavor sweet, juicy, extra fine. A hardy strong grower and profuse bearer. The best late variety. August $\mathrm{I}$. 


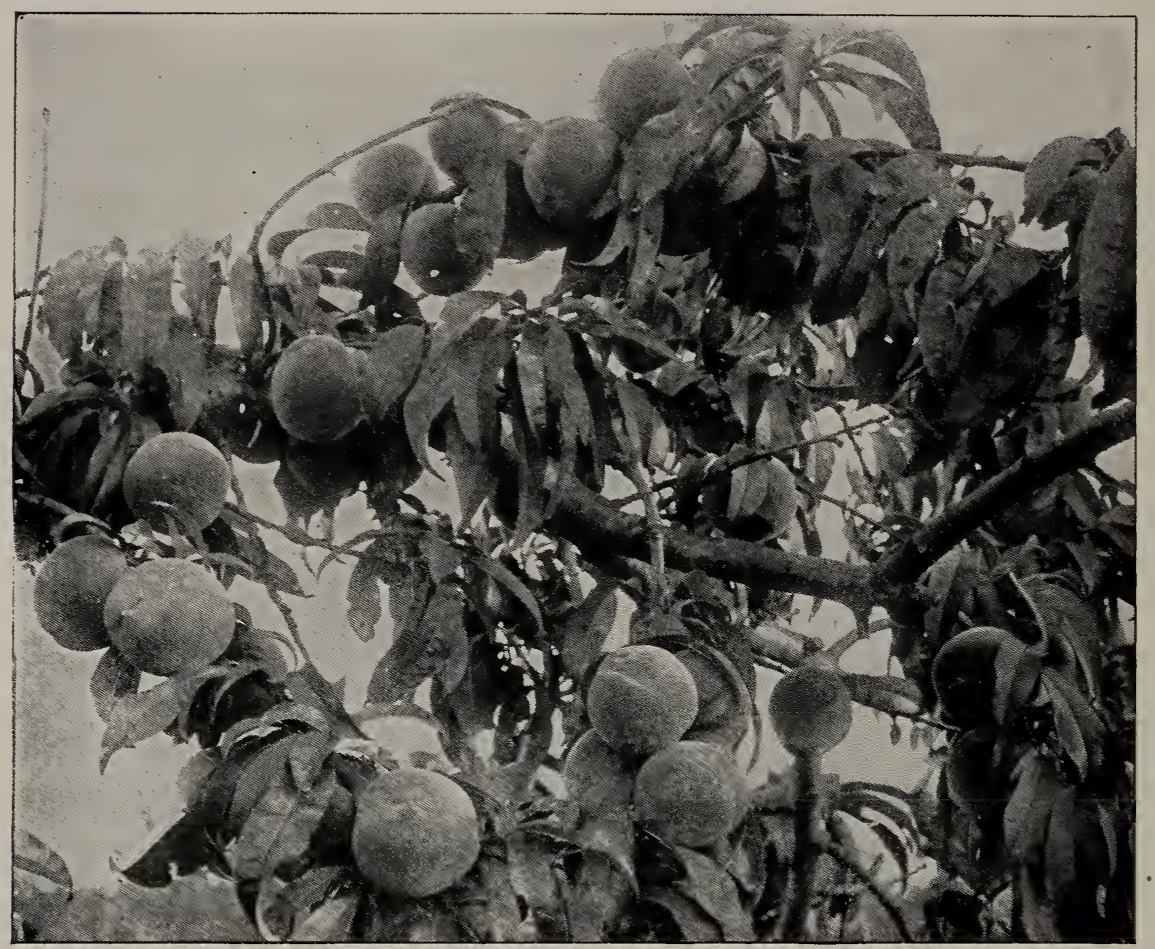

A Branch of Elberta Peaches

\section{Peaches}

Alexander. Medium to large size; skin greenish white, nearly covered with deep, rich red; flesh melting, juicy, sweet. The tree is vigorous and productive; ripens two weeks before Hale's Early. This is one of the largest and best of the extra-early varieties. It is very valuable for market as well as for home use.

Bokhara. Twenty-eight degrees below zero and a crop. One of the hardiest Peaches yet brought out. Seed was imported from Bokhara, Asia, by American missionaries. The report of the Iowa exhibit at Chicago has this paragraph by Professor Hansen: "In the Iowa exhibit were shown a number of plates of new Bokhara Peaches. One measured 7 inches in circumference. It did not rot easily, being inclined to shrivel rather than to rot. I saw one plate in good condition September 26 , which had been exhibited at the Iowa State Fair the first week in September. Fruit yellow, with red cheek, skin tough, flesh good quality. A perfect freestone."

Champion. A large, handsome early variety, creamy white, with red cheek, sweet, rich and juicy. Hardy and productive. August.
Coolidge's Favorite. A most beautiful and excellent Peach, of medium size; skin white, delicately mottled with red; flesh pale, juicy and rich. Tree vigorous, hardy and productive. A valuable variety. End of August.

Crawford's Early. A magnificent, large, yellow Peach, of good quality. Its size and beauty make it one of the most popular orchard varieties. Fore part of Sept.

Crawford's Late. Very large, roundish; skin yellow, with a beautiful dark red cheek; flesh rich, yellow, melting, with sweet luscious flavor; worthy of universal cultivation as table and market sort. Latter part of September.

Crosby. Originated at Billerica, Massachusetts, about 1875 , and recently brought to general notice on account of its extreme hardiness, bearing full crops of choice, attractive fruit when all other sorts have been blasted by frost. The fruit is of medium size, roundish, slightly flattened, with a distinct seam, bright orange-yellow, streaked with red on the sunny side; flesh yellow, of a mild, pleasant flavor. Tree of low, spreading growth, similar to Hill's Chili. Promises to be very valuable for general cultivation. In season about with the Oldmixon. 
PEACHES, continued

Elberta. Originated in Georgia, and is being planted most largely in the South, where it is regarded as the best market variety. Fruit large, yellow, with red cheek; flesh yellow, firm, juicy, fine quality. Tree very hardy and exceedingly productive. It is equally valuable in the North, and is one of the best general sorts for all sections. Ripens with Crawford's Early. During the past season this variety has become very popular. Exceptionally large and fine.

Fitzgerald. A chance seedling found in Ontario, Canada, outside the Peach belt, where it has borne regularly-fruit very large, pit small. Very hardy and productive. Season, early September.
Hale's Early. Raised in Ohio. Medium size; flesh white, first quality. Ripens middle of August.

Heath Cling. Very large; flesh white, juicy and melting. Good keeper and shipper. October.

Hill's Chili. Large, downy, tame yellow, with slight blush; flesh yellow, luscious and well flavored; pit small. Tree hardy and productive. Bears large crops when most other sorts fail. Late Sept.

Salway. An English Peach. Large, roundish; skin creamy yellow; flesh deep yellow, juicy, melting rich.

Wager. Medium, yellow, good quality. Tree hardy, healthy, long-lived, productive. Early September.

\section{PEACHES IN THE NORTH}

It is generally considered that this class of fruit can be raised only in the far South, but some of our best horticulturists have demonstrated that this is not true.

By planting small trees and leaning them in the direction that you wish to lay them down in the winter, and then in the fall digging out a few spadefuls of dirt on the side that it is desired to bend your trees down, you will find that you can easily bend them down and pin them to the ground. They should then be covered with coarse straw, cornstalks, leaves or any other similar materials. It is better to have some mulch under the tree before it is laid down, so that the branches will not come to the ground, and under the mulch and scattered through it there should be plenty of poisoned bait for mice, as they are the worst enemy to trees protected in this way. Common corn bread, in small pieces, and covered with arsenic, is as good a bait as can be used.

When spring comes, remove the litter and straighten the trees up; fill in the dirt, and you will find in a few years that you will.be able to raise good crops of Peaches even where the mercury often goes as low as $35^{\circ}$ to $40^{\circ}$ below zero. You will also find that the fruit raised in this way will be even more beautiful in appearance and much finer in flavor than that raised in the South.

\section{Pears}

Bartlett. One of the most popular Pears; large, buttery and melting, with a rich musky flavor. A vigorous, erect grower; bears young and-abundantly. Middle to last of September.

Bessemianka. A small Russian Pear, imported by Professor Budd. Tree a slow grower and hardy, but subject to blight; fruit of good quality, small and much thicker at the stem end than the ordinary Pear.

Duchesse d'Angouleme. Very large, buttery, rich, juicy, excellent. It succeeds to perfection and is the most popular market variety as a dwarf. Season, October and November.

Flemish Beauty. A large, beautiful, melting, sweet Pear. Tree very hardy, vigorous and fruitful; succeeds well in most parts of the country. September and October.

Kieffer (Kieffer's Hybrid). Said to have been raised from seed of the Chinese Sand Pear, accidentally crossed with Bartlett or some other kind. Large; skin rich golden yellow, sprinkled thickly with small dots, and often tinged with red on one side; flesh slightly coarse, juicy, melting, with a pronounced quince flavor. Tree very vigorous, and an early and great bearer. October and November.

Seckel. Medium size, yellowish brown, with a red cheek; melting, sweet, spicy, very rich and delicious. The standard of Excellence. Tree a slow but stout, erect grower; hardy and productive. October. 


\section{Plums}

Cheney. A strong, upright-growing tree, very hardy, and one of the very best varieties for the extreme North. Fruit large, of fair quality. Tree an early and abundant bearer.

Damson. Large, dark purple, very showy, often measuring two inches in diameter; fine, juicy and sweet. Season, September.

De Soto. Tree perfectly hardy, a regular and abundant bearer; fruit medium size and of fine quality; color light red; ripens very early. This tree is liable to overbear, and, if very heavily loaded, fruit should be thinned.

Forest Garden. Hardy; bears profusely; one of the earliest Plums; large, being I to $1 \frac{1}{2}$ inches in diameter, oblong, color mottled red and yellow; skin thin; juicy, sweet and rich. Ripens from August I to 25 .

Green Gage. Small; considered the standard of excellence; slow grower, Middle of August.

Hawkeye. This variety is a native of Iowa, perfectly hardy, and fruit is as large as Lombard. Season, September.

Mooney. A good grower and regular producer. Fruit fair size and good quality.

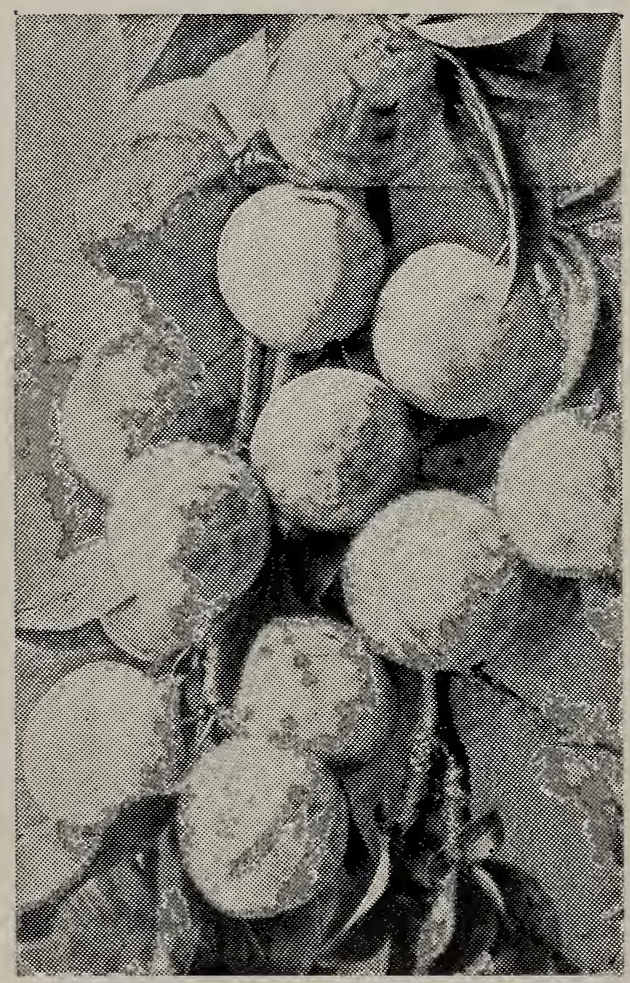

Burbank Plums (see page I5)
Stoddard. Large, round and red; very productive. Tree and fruit closely resembles the Hawkeye, but of somewhat better quality and a good market sort.

Surprise. A variety introduced at Sleepy Eye, Minn. Tree a beautiful, symmetrical grower, with fine foliage. Best Plum yet introduced in that state; meaty, fine flavor, very large and red, with many light dots on the skin, hangs well to the tree, a good bearer and a good keeper; fine for culinary purposes.

Wild Goose. Fruit large, round, oblate, light red; skin thin. This Plum is a clingstone. The leaf of this variety is peach-like in shape, margin finely toothed. Ripens early, but is of poor quality, but on account of its productiveness and beauty is the most popular of native Plums.

Willard. Size medium, color red and attractive; vigorous, hardy and productive very early, about July I 5. Will keep in good condition a long time after picking.

Wolf. Tree vigorous and hardy. Fruit of good size and fair quality for eating from hand, and hard to equal for cooking purposes.

Wyant. Tree a spreading grower, fine foliage, very prolific; superior to Weaver in quality, and much more beautiful. Fruit medium to large, slightly oblong and distinctly flattened; purplish red in color, inclined to orange on the shady side; skin thick; flesh rich yellow. This variety is reported by Professor Goff as one of the most productive at the Wisconsin State Experiment Station.

Yellow Egg. A very large and beautiful egg-shaped yellow Plum. Excellent for cooking. Tree a free-grower and good producer. End of August.

\section{EUROPEAN AND JAPANESE PLUMS}

Abundance. Large to very large, oblong, amber, nearly covered with bright red and overspread with a thick bloom; flesh orange-yellow, juicy, melting, and of delicious sweetness; stone small and flesh readily parts from it. Tree strong grower and an early and profuse bearer. Ripens in advance of other Plums. Valuable for canning and market. This variety has attracted much attention throughout the country, and is very highly recommended.

Burbank. It is claimed by many that the Burbank Plum stands at the head of the celebrated Japanese varieties. It is proving remarkably successful the country 
European and Japanese Plums, continued over. No other Plum ever became so popular in so short a time. This is because it is practically curculio-proof, and is very free from black-knot. It has been fruited from seven to nine years in this country, and is said to stand $30^{\circ}$ below zero. Ripens in August. It seems to succeed on any soil-sand, clay or loam. It can be picked green, and will ripen and color up perfectly, and will not lose its flavor. Will keep fully two weeks in perfect condition after ripening. Abundanty early bearer. Fruit large, roundish, dark red or purplish, with thin lilac bloom; flesh amber-yellow, melting, juicy, with rich sugary flavor; stone small and free. Bears very young.

Grand Duke. Fruit oval with a short neck. Skin almost black, but reddish when shaded and covered with bloom; flesh yellow, adhering closely to the stone; with a sweet, rich flavor when fully ripe. Leading
Plum growers state that it is one of the most profitable Plums for market. Sept.

German Prune. Medium, oval; purple or blue; juicy, rich, fine. Tree vigorous and very productive. September.

Lombard. Medium, oval, violet-red; juicy, pleasant and good; adheres to the stone. Tree vigorous and very productive. A valuable market variety; one of the most hardy and popular. Middle to last of August.

Satsuma (Blood). Large, globular with sharp point. Color, purple and red with bloom; flesh firm, juicy, dark red or blood color; fine quality; pit very-small. August.

Wickson. Originated by Burbank. A sturdy, upright grower. Fruit remarkably handsome, deep maroon-red, covered with white bloom; stone small; flesh fine texture, firm, sugary and delicious. Excellent keeper and shipper; will keep two weeks after ripening.

\section{Why Does the Plum Fail?}

One of the principal reasons for the failure of Plums throughout the Northwest is that they have been propagated on tender roots. Throughout the East and South the Plum is usually propagated on Myrobalan, a native plum of France, or on Marianna, the wild Plum of the South. These roots will not stand the severe cold of our northern winters, and when the root dies the tree, of course, is a failure. Our trees are all worked on our native wild Plum, which is perfectly hardy. In planting Plums it is well to plant several varieties in a group, as some sorts seem not to fertilize their own blossoms.

\section{Cherries}

Bing. A native of Oregon, fruit very large, bright and glossy. Color very dark crimson, one of the largest Cherries ever produced, and of the most excellent quality. Season, July.

Black Tartarian. Very large, bright purple, glossy black; juicy, rich and fine. Tree a rapid, vigorous, upright grower, and great bearer. One of the popular kinds. Ripens last of June and beginning of July.

Compass. Originated by H. Knudson, Springfield, Minn. A cross between the Miner plum and the Sand cherry. Fruit a little larger than a medium cherry; color red; round; skin moderately thick; flesh firm, juicy, coarse; stone medium; flavor subacid; quality good; good bearer; very hardy; leaves resemble the Sand Cherry, as does the $t$ wig and the color of the bark. It is at present being widely distributed by the nurserymen. Of value in sections of the Northwest. Plum type in general appearance, but in quality of fruit resembles the Cherry. Season, July 20 to 30 .

Dyehouse. Partakes of both the Duke and Morello in wood and fruit; a very early and sure bearer; ripens a week before the Early Richmond, of better quality and quite as productive. June.

Early Richmond. Fruit fair size, red, sour. Tree a good bearer.

English Morello. Large, dark red, acid, tender, juicy and rich; tree dwarfish, and in this section one of the hardiest of the old sorts.

Lambert. One of the largest of all; heart-shaped; dark purplish red, turning to almost jet-black when fully ripe. Flesh firm, solid, rich and juicy, with sprightly flavor. Seed very small for so large a fruit. Tree rugged, strong-grower, hardy. Enormous bearer. Late July.

Lewelling (Black Republican). Seedling raised by Seth Lewelling of Oregon; large size, black, sweet, with purplish flesh; late and a good shipper. Tree a moderate grower; an early and profuse bearer. July.

Montmorency, Large. A fruit much larger than Early Richmond; red, acid, and an extremely fine canning fruit. Tree very vigorous. 


\section{CHERRIES, continued}

Ostheim. A tree said to be of Russian or German origin; very hardy, having stood the test well up into Minnesota. Fruit of good size, very dark red, acid. This promises to be a success in all of our northern states.

Rocky Mountain Dwarf. This Cherry is practically the same thing as the Sand Cherry of Nebraska.| The fruit, when well grown, is about the size of Early Richmond; dark red in color and sweet. It is a very slow-growing plant, and is more properly described as a shrub than a tree. It is peculiarly well adapted to dry sections and dry locations. We regard it as perfectly hardy as far north as Minneapolis. Where the varieties of cultivated Cherries can be grown, however, we would not recommend its planting.

Royal Ann. (Napoleon Bigarreau.) A magnificent Cherry of the largest size; pale yellow, becoming amber in the shade, richly dotted and spotted with deep red, and with a bright red cheek; flesh very firm, juicy and sweet; tree a rapid grower and immense bearer. The most popular all-round cherry for canning, preserving and shipping. Late June.

Wragg. Rather a dwarfish tree; a good bearer; fruit light red, and late.

\section{Quinces}

Anger's. A free bearer of good-sized fruit, which keeps well, but not equal in quality to some other sorts.

Orange. Fruit large, bright yellow, of excellent flavor.

\section{Grape-Vines}

We grow our vines on open prairie land and believe them far superior to vines grown in the moist lake climate and gravelly soil of western New York. They are also free from the exposure to insects and diseases such as are common among the vineyards of the East. They also have the added advantage of having been tested in this climate.

Agawam (Rogers' No. I5). One of the most reliable of the hybrid Grapes. Bunches large, berries very large, dark red. Ripens with or soon after Concord, and is of peculiar, aromatic flavor.

Beta. A cross between Carver and Concord; perfectly hardy, productive; fruit of medium size; early. The principal value of this Grape is in the extreme North where it will stand without protection.

Brighton. A new variety, originating at Rochester, N. Y. Is a cross between Concord and Diana Hamburg. Bunch medium to large, compact, shouldered; berries medium, dark red; skin thin; flesh tender, sweet; quality "best. Vine a vigorous grower, healthy, with no more tendency to leaf-blight in unfavorable seasons that Rogers' Nos. 4, I5, I9, or Salem. Is productive and ripens early, about with Delaware. Is of fine quality, but not so good if allowed to remain on vine till fully ripe. It then becomes nearly black, and to some extent insipid.

Campbell's Early. Strong grower, with large, healthy foliage; productive; its keeping and shipping qualities are equaled by no other early Grape. Ripens with Moore's Early. Bunch and berry, large glossy black with blue bloom, sweet and juicy; seeds few and small, part readily from the pulp. Stands at the head of early black grapes for quality.
Champion. A large Grape, of medium quality. Its chief value consists in vigor of plant and earliness, rendering it a valuable sort to plant where the season is short.

Clinton. Bunches small to medium, compact, long and not usually shouldered; berries small and black; skin thin, but tough; flesh juicy, spicy and acid. The chief value of this Grape lies in its extreme hardiness. It is nearly, if not quite as hardy as the wild Grape. Its fruit is unsurpassed for canning.

Concord. A large, handsome Grape, ripening in latter part of September; very hardy, productive and reliable; succeeds well over a great extent of country. One of the most popular market Grapes.

Delaware. Bunch small to medium, compact, usually shouldered; berries medium, red; skin thin, but firm; flesh juicy, very sweet and refreshing. Vine hardy, moderate grower and productive. Ripens with Concord. Requires rich soil and good culture. Fruit of best quality for table. It is esteemed in many localities as the best American Grape, all things considered. Should be in every garden and vineyard.

Elvira. Very vigorous, strong, healthy grower. White; bunch and berries medium size, very compact and very productive, often growing four or five clusters 


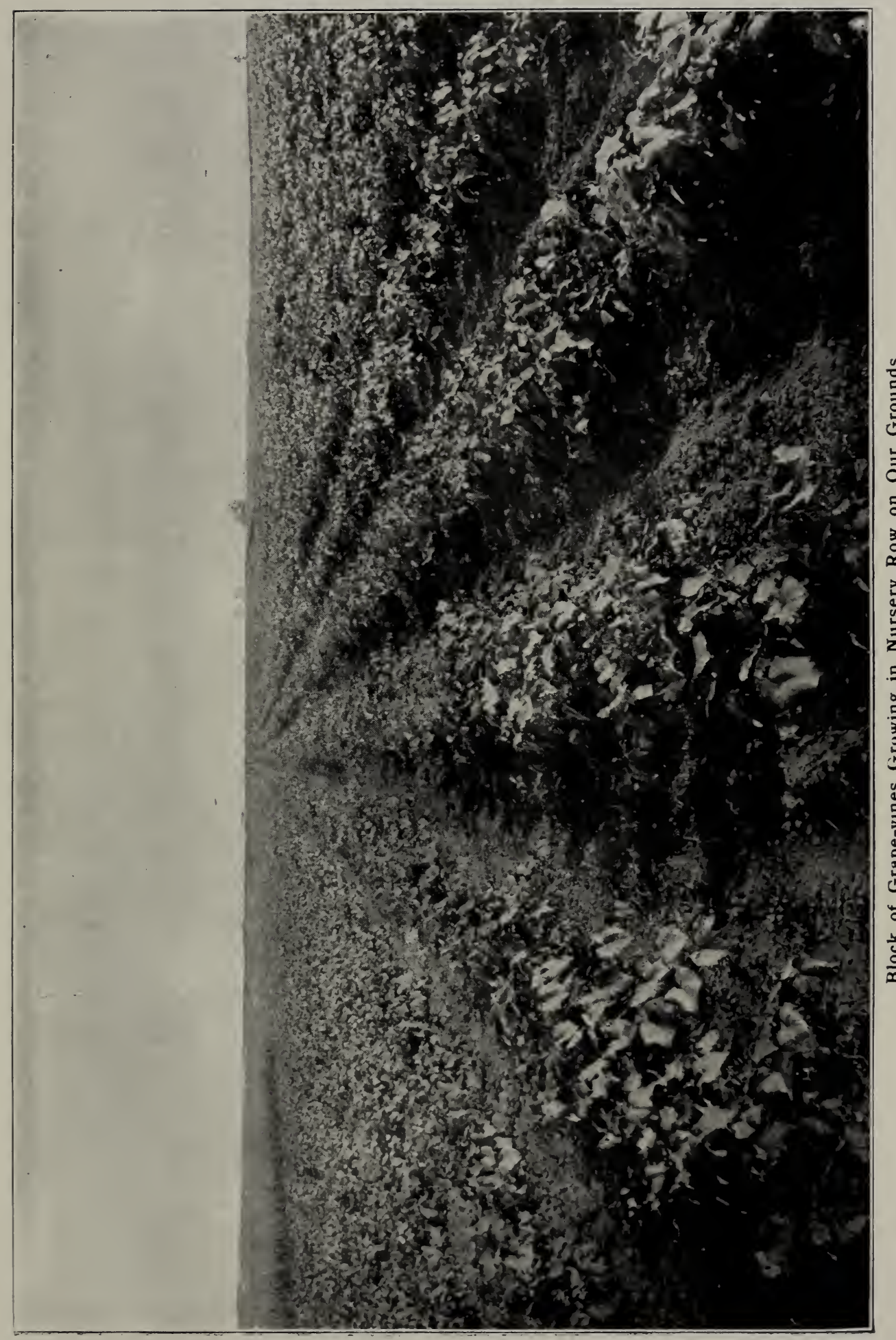




\section{GRAPES, continued}

on a single cane. Ripens about with Catawba. Very hardy Grape. Liable to crack.

Janesville. First produced at Janesville, Wis. Very hardy; fruits successfully in far northern localities. . Ripens early and is the hardiest northern Grape grown.

Martha. A seedling of the Concord, which it resembles in growth and hardiness. Bunch of good size and berry large, of pale green or light color; sweet, juicy, sprightly. Ripens with the Concord.

Moore's Early. Cluster medium size, berry quite large and dark. Season about two weeks earlier than Concord. A vigorous grower and abundant bearer. Vine very hardy. Highly prized for its earliness and hardiness.

Moore's Diamond. Color white; bunch and berries large. Healthy, strong grower, hardy, and where known is very popular. Quality excellent. This new Grape has evidently come to stay. Ripens with Delaware.

Niagara. Said to be a cross of Concord and Cassidy. Bunch medium to large,

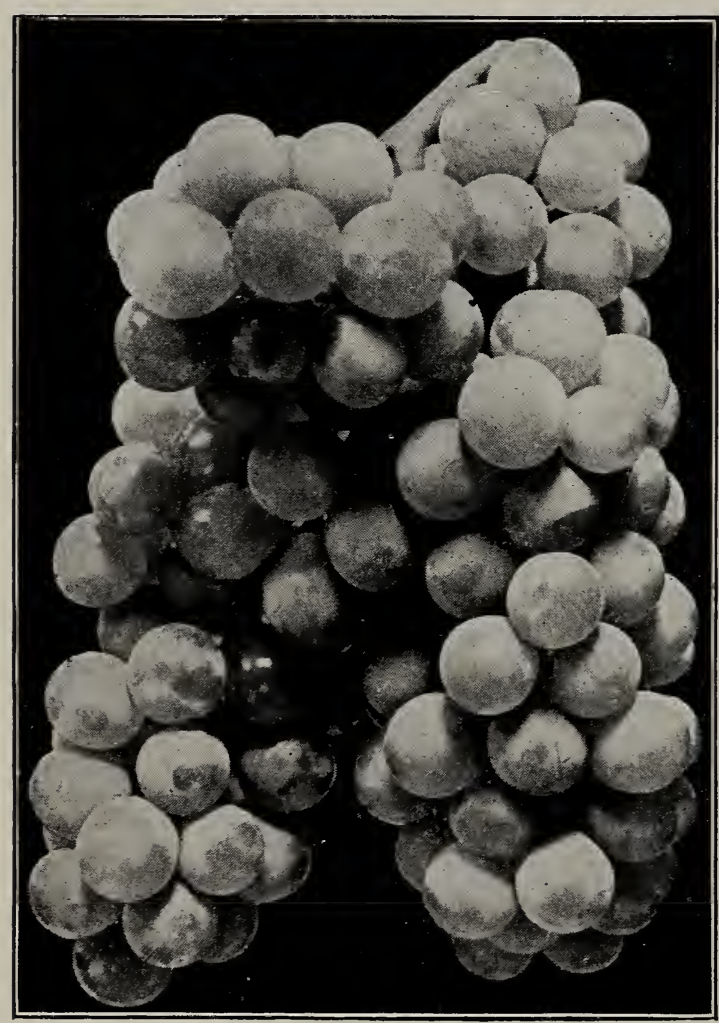

Moore's Diamond compact, occasionally shouldered; berry large, roundish, uniform; skin thin but tough, pale green at first, changing to pale yellow when fully ripe, with a thin, whitish bloom; flesh slightly pulpy, tender, sweet, not quite equal to the Concord. Before it is fully matured it has a very foxy odor, which disappears, to a great extent, later. Vine vigorous, healthy and productive; foliage thick and leathery. Ripens with the Concord. All things considered, probably the most valuable white Grape in cultivation.

Pocklington. A seedling of the Concord. Bunch medium to large, generally shouldered; berry large, roundish, light golden yellow when fully mature; flesh pulpy, juicy, of fair quality. Vine very hardy, healthy, vigorous and productive; leaves large, tough and downy. Ripens after Concord. It will require favorable seasons and good locations to ripen it satisfactorily in this region.

Worden. This is, beyond question, the best black Grape known. It is a seedling of Concord, ripens about ten days to two weeks earlier, and is fully equal to it in quality. It is a vigorous grower and much better bearer; in some places said to outyield Concord two to one.

\section{Remarks}

The soil for the Grape should be dry; when not naturally so, should be thoroughly drained. It should be deeply worked and well manured, always bearing in mind that it is an essential point to secure a warm, sunny exposure.

The best grape-vine trellis is probably the wire trellis. This is constructed by planting posts as far apart as you choose to have the length of your trellis; stretch the wires, four in number, about eighteen inches apart, letting them pass through stakes at proper distances from each other to support the wire. As the wires are concontracted by the cold, and are likely to break or sway the posts from their places, they should be loosened as cold weather approaches.

To secure the best results, annual and careful pruning is essential. The following is regarded as the best method. Commencing with a good strong vine, permit it to grow the first season without pruning. In November following cut back the growth, allowing but three or four 


\section{GRAPES, continued}

buds to remain. The following spring allow but two of the strongest buds to throw out shoots. These, in the fall, will be from seven to ten feet long, and should be cut back within four or five feet of the root. The next spring the vine should be fastened to the lower wire of the trellis. When growth commences, pinch the buds so that the shoots will be from ten to twelve inches apart. As these grow, train them up perp?ndicularly to the second, third and fourth wires. No fruit should be allowed to set above the second wire of the trellis.

During the season, when the shoots have reached the upper part of the trellis, they may be pinched to prevent further growth. After the fruit is gathered and the vine has shed its foliage, the cane should be cut back to two buds of the old wood. The following spring allow but one bud to throw out a shoot, and treat as in the previous year. This system of pruning should be followed each year. After the vine has undergone the fall pruning, it should be laid upon the ground and covered to protect it through the winter. Grape-vines should be topdressed in the spring.

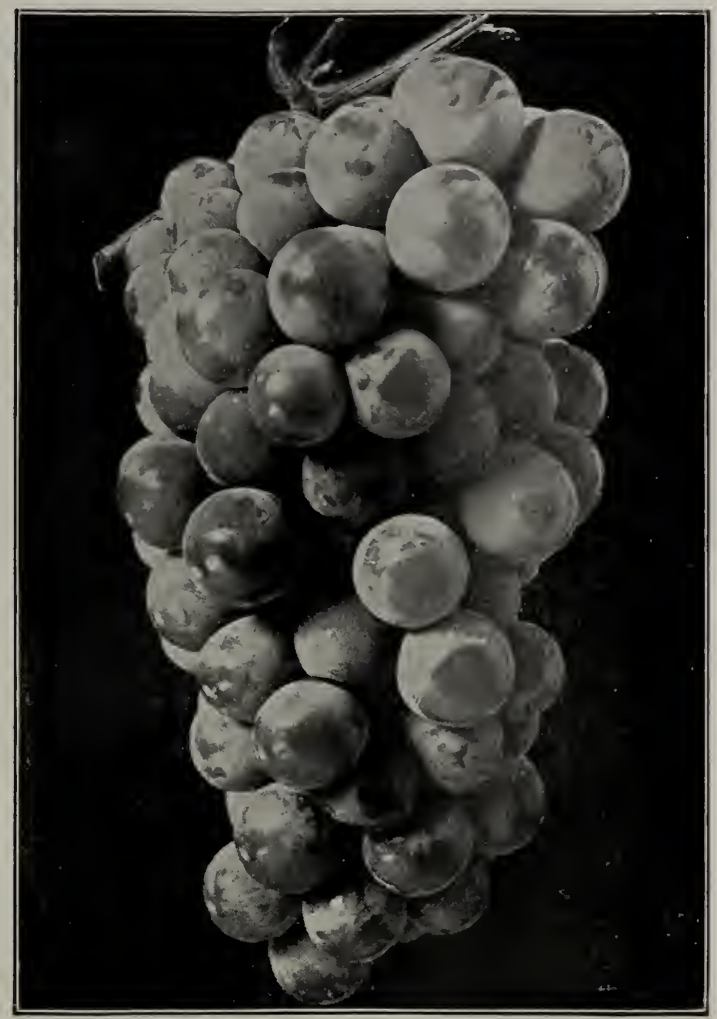

Niagara (see page I8)

\section{Gooseberries}

Plant Gooseberries on good, strong land, and keep them well cultivated or heavily mulched.

The fruit is useful for cooking when green or ripe, and may be canned with such facility that it is being cultivated more extensively every year for home use and market.

Downing. A seedling of Houghton. Fruit large, two to three times the size of Houghton; whitish green; flesh soft, juicy, good; plant vigorous and prolific;, excellent for family use, and very profitable for market. Planted more extensively than any other.

Houghton. Vigorous grower; branches rather slender; very productive; not subject to mildew; fruit of medium size; skin smooth, pale red; flesh tender and good.

Industry. Bush a strong grower, and the most productive of European varieties; fruit large, dark red, mild, sub-acid, sweet and good-flavored; one of the best for market either green or ripe. This variety is not good in sections where mildew is prevalent.

Pearl. The most prolific Gooseberry known. One bush produced 2,500 berries. It is free from mildew and is larger than the Downing. The color is light green and quality first-class. Being thoroughly tested, it promises to be the most valuable variety of recent introduction and the best of its class.

Red Jacket (Joslyn). A most prolific and valuable Gooseberry; as large as the largest; berry smooth; very hardy; quality and foliage best of any Gooseberry known. The introducer says of it: "For ten years it has stood close to Triumph, Crown Bob, Whitesmith, Smith's Improved, Downing, and more than a dozen other sorts; and whilc. these others have all mildewed in leaf and fruit, mildew has never appeared on Red Jacket."

Smith (Smith's Improved). Grown from the seed of Houghton; the fruit is large, oval, light green in color; flesh moderately firm, sweet and very good; the plant is a vigorous grower, hardy and productive. 


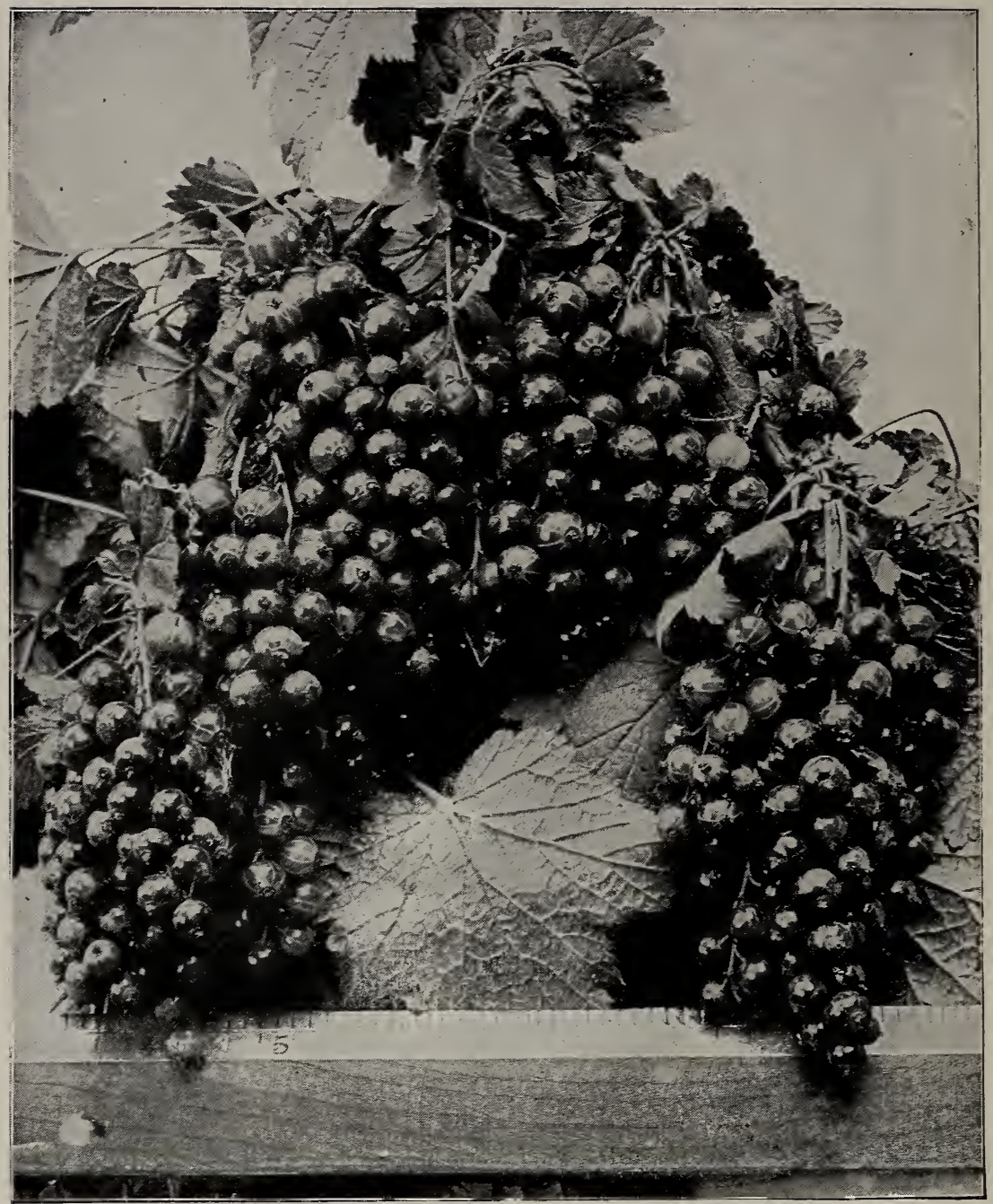

Long Bunch Holland Currants

\section{Currants}

Black Naples. A vigorous plant; fruit very large.

Cherry. A very large, red Currant, with short clusters; a vigorous plant and one that bears well if planted on strong land and well cultivated.

London Market. For many years this variety has been fruiting in Michigan, where it is now planted extensively and regarded as the best market variety of that great fruit state. Plant is extremely vigorous, with perfect foliage, which it retains through the season; an enormous cropper. Ripens with Victoria, is larger in both bunch and berry; a better bearer. Red in color, this is regarded as the best Currant in North Dakota. For any use -home garden or market-one of the best.
Plant in well-drained land, and mulch heavily

Long Bunch Holland. A strong, stumpy growing plant which grows to an immense size. The plant does not bear young, but yields enormous crops; berry large; clusters long; color red.

Perfection. A cross between Fay's and White Grape, retaining the valuable characteristics of both parents. Beautiful, bright red, as large or larger than Fay's, holding its size to end of bunch; easy to pick; a great bearer, superior to any other large sort; less acid and of better quality than any other large Currant in cultivation; large, healthy foliage; intermediate in growth between Fay's and White Grape. Kept well cultivated and fertilized they will regularly produce heavy crops of extra-size fruit of the very best quality. 


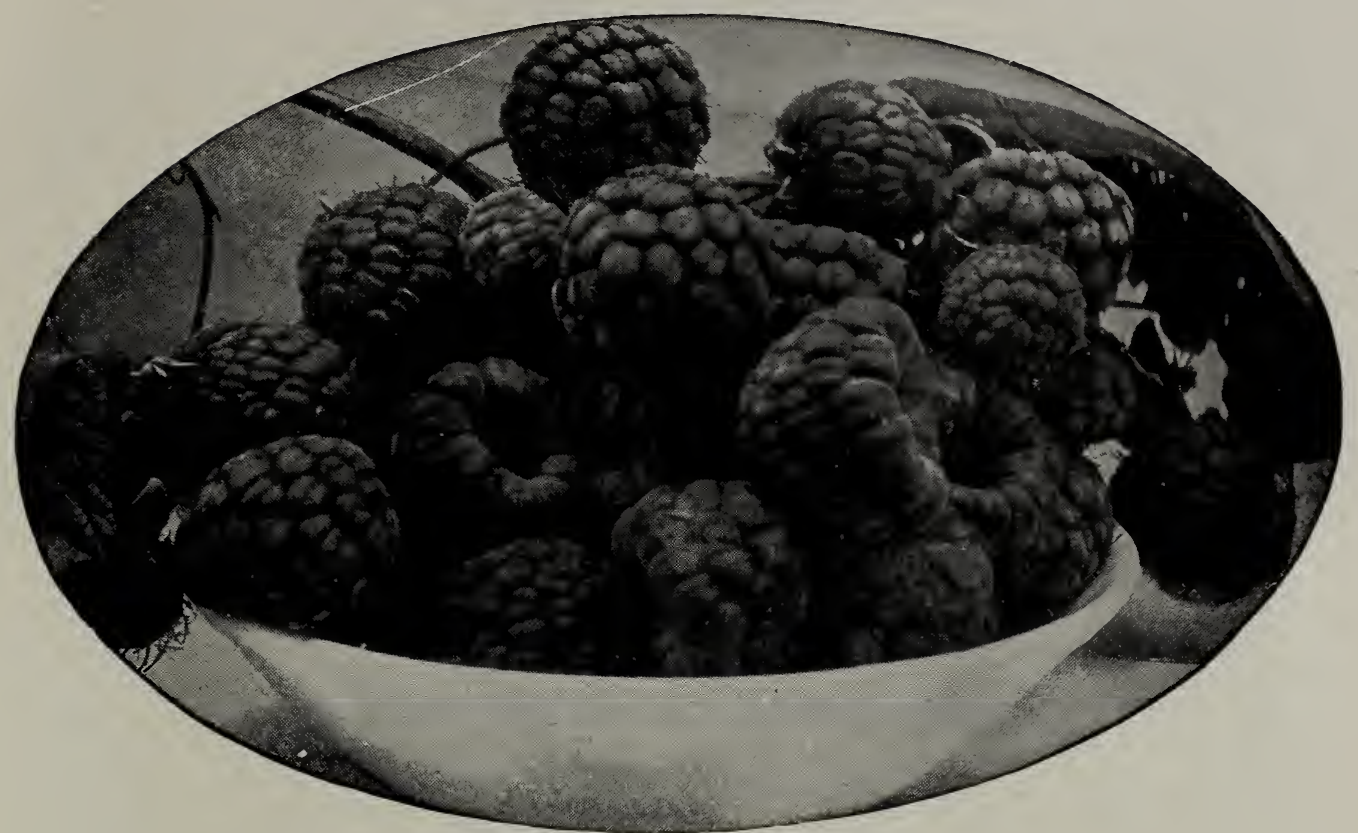

A Dish of Cuthbert Raspberries

CURRANTS, continued

President Wilder. One of the strongest growers and most productive. Bunch and berries very large, bright, attractive red color, even when dead ripe; hangs on bushes in fine condition for handling as late as any known variety. Compared with the celebrated Fay's, is equal in size, with longer bunch, better in quality, with much less acidity, ripens at same time, continues on bush longer, fully as prolific, in some trials largely outyielding it.

Red Dutch. This is one of the best of the old standard sorts. A vigorous plant; bears well.
Victoria. Fruit medium size and bright red; clusters long; season late; a vigorous grower.

White Dutch. This is probably better known than any other white Currant; bears well.

White Grape. A very large berry, and of the best quality; highly esteemed for table use. The best of all white kinds. Plant on rich soil.

\section{TREE CURRANTS}

This is an upright tree form of any variety mentioned herein.

\section{Raspberries}

Our Raspberries are not the usual tip plants which are so commonly sent out through the West, and which are so easily destroyed by a little exposure, but have been transplanted and grown one year from the tip. This gives our customers a strong, woody plant which will better stand transplanting, and will make stronger growth when planted.

CUltuRAL Notes.-Raspberries may be planted either in the fall or spring, but when planted in the former season it is a good plan to mulch the ground heavily with manure; when plants have fruited the old canes which have borne a crop of fruit should be removed in the fall; it is also best to thin out the weaker canes, leaving only five or six strong stalks in a hill. These should be laid down and covered lightly with leaves, straw or dirt; the latter is the best, as it lessens the liability of injury from mice. In the summer season, when canes have grown to about three feet, pinch off the tip; this will make them branch and increase the bearing surface.

Black Diamond. A very large variety, and ripens early; the fruit is very sweet and of fine flavor. Pulpy, and has few seeds.
Cardinal. The best of the purple Raspberries and a most desirable variety for home use. Vigorous in growth, ornamental in appearance and enormously productive. 


\section{RASPBERRIES, continued}

Columbian. New. Purple; very vigorous grower; canes often ten to sixteen feet in length and more than one inch in diameter; very hardy. Fruit large and delicious for table or canning. Excellent shipper. Grown from tips or sprouts.

Cuthbert (Queen of the Market). Medium to large, conical, deep rich crimson; very firm, sweet and good; hardy. Season medium to late. Unquestionably one of the best varieties for market on account of its prolific-bearing quality.

Gregg. One of the most valuable varieties of the blackcap family; fruit very much larger than the Mammoth Cluster, but not quite so good in quality; ripens some days later; hardy. A vigorous grower and great yielder.

Hilborn. A strong, vigorous plant; growing taller than the Older. Berry large, black and of fine quality. This variety has done best of all on our grounds. Its blossoms mature late and are seldom caught by the frost.

Kansas (Blackcap). A valuable early variety; very large, handsome, firm and of excellent quality; very hardy and productive. One of the best blackcaps.

King. Pronounced the best early red Raspberry by many of the leading horticulturists. Plant a strong grower, very hardy and productive. Berry is firm, a good shipper; large size; beautiful bright scarlet color; ripens with the earliest. Prof. W. J. Green, of Ohio Experiment Station, says: "King has proved the best early red Raspberry. It is large, bright red, quite firm, and of good quality."
Loudon. This variety originated at Janesville, Wisconsin, and is usually considered the best of all red Raspberries for the extreme North. It is reported perfectly hardy at St. Paul. Fruit large, good color and of fine quality. Very productive.

Older. A new blackcap of large size, which originated in Buchanan county, Iowa. Thought by some who know it, to be the best of the black varieties.

Shaffer's Colossal. This variety resembles the Columbian in fruit and is one that has been highly esteemed, but of late years the canes have been so infested with fungus and insect pests that the variety has been practically discarded. The Columbian is practically the same in fruit, and better in every other way.

Sunbeam. The first of our many thousands of Raspberry seedlings to be named. First sent out, spring 1906. Female parent a wild red Raspberry, from Cavalier county, North Dakota, near the Manitoba line. Male parent, Shaffer's Colossal, from New York. Plant extremely vigorous, productive, purple-caned, sprouts freely. Fruit of fair size and quality. Worthy of trial where Raspberries winterkill as it has endured $4 \mathrm{I}^{\circ}$ below zero without protection. It endured last winter perfectly at Bismarck, North Dakota, without protection, and other good reports have been received.

Turner. One of the sweetest of berries; bright crimson in color, and perfectly hardy. A good bearer.

\section{Blackberries}

We grow our Blackberry plants from root-cuttings, and in this way get plants with plenty of fibrous roots, which make sure the growing of the plant. In fruiting patches of Blackberries there will spring up many plants from the root, and these are the plants that are usually dug up and sent out to the trade. They have but few, if any, fibrous roots, and are much more apt to die when planted, and will not make the growth after planting that the plants will when grown from root-cuttings. Valuable for market purposes.

Ancient Briton. This has been much planted for many years in Wisconsin, and has proved one of the most profitable fruits for market growing. Plant hardy and very productive; fruit large and sweet.

Rathbun. A strong, erect grower, with strong stem branching freely; will root from tip of branches like a raspberry. Forms a neat, compact bush, four to five feet high, producing its immense fruit abundantly. Fruit is sweet and luscious, without hard core; of extra-high flavor; jet-black, small seeds; firm enough to ship and handle well. Very large size, resembling the Wilson and fully equal to that grand variety.

Snyder. One of the hardiest and best known sorts grown in the West. Fruit large and of good quality when fully ripe; very vigorous and productive. Ripens but little later than Early Harvest. 


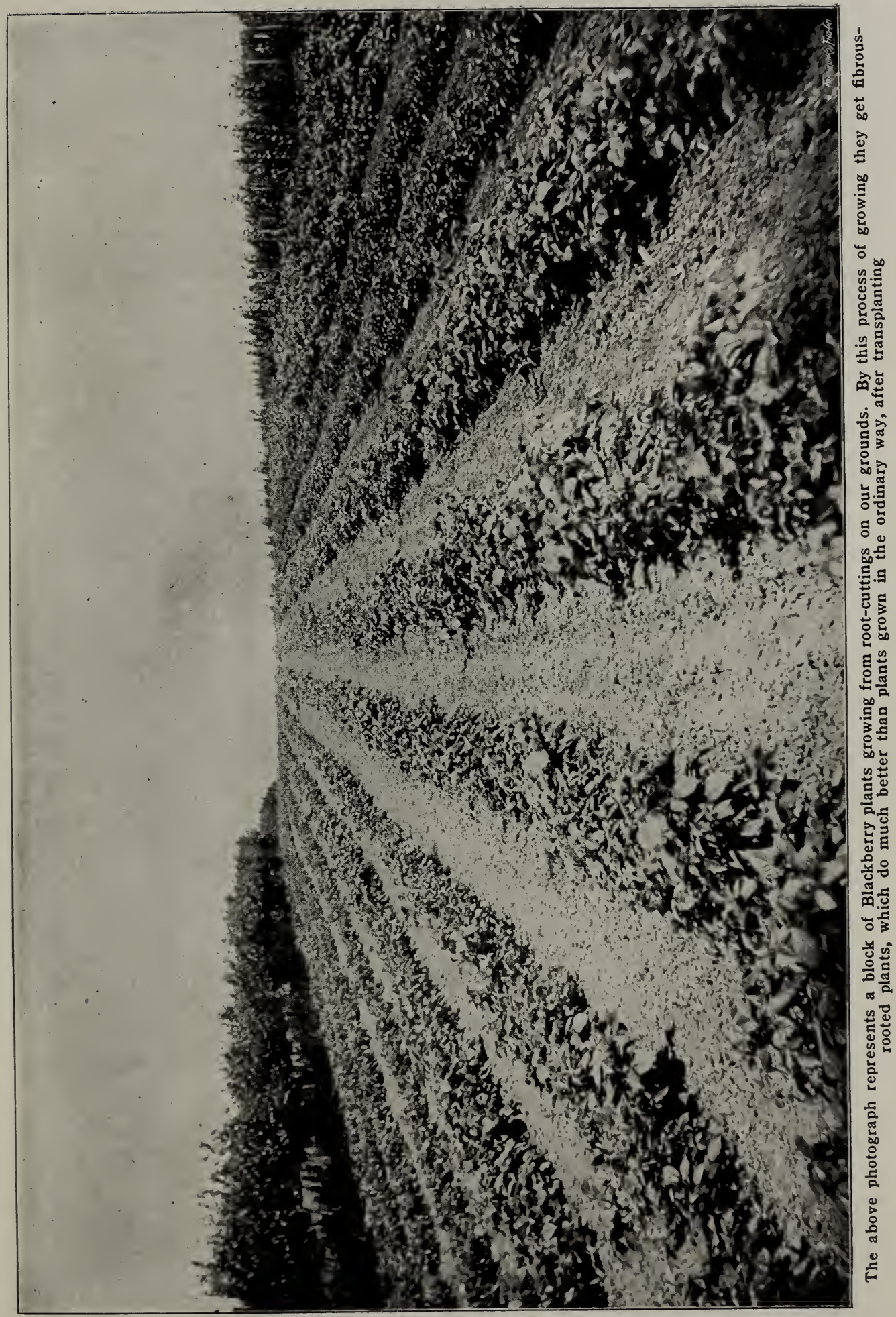




\section{Miscellaneous Fruits}

\section{Dewberry, Lucretia}

Fruit much resembles the blackberry, but very much larger; an enormous bearer. Plant runs on the ground and needs same winter protection as blackberry.

\section{Dwarf Juneberry}

Fruit hard to distinguish from blueberry or huckleberry. The shrub grows about four feet high, and bears annually an abundant crop of fruit, which ripens in June.

\section{Elderberry}

A bush hardy nearly everywhere in the Northwest; fruit desirable for culinary purposes, as well as a good wine maker.

\section{High-Bush Cranberry}

Bush closely resembles the snowball; perfectly hardy in northern Minnesota. This shrub bears extremely well; color of fruit bright scarlet; hangs in clusters; ripens in fall and will hang on all winter. It makes a very fine jelly of beautiful color. The plant is highly esteemed both for fruit and ornamental purposes.

\section{Loganberry}

This berry is unlike any other in existence, being a hybrid between the raspberry and the blackberry. The fruit is sometimes an inch and one-quarter long, dark red, as large as the largest blackberry, and produced in immense clusters. It partakes of the flavor of both the blackberry and raspberry, a mild, pleasant, vinous flavor, delicious and peculiar to this berry alone; seeds small, soft and few; fruit ripens early, just after strawberries, and before blackberries or raspberries. The vine or cane of the Loganberry grows entirely unlike either the blackberry or raspberry. It trails or grows upon the ground more like a Dewberry. It is excellent for the table, eaten raw or stewed, and for jelly or jam it is without an equal.
Ripe in May. This fruit originated on the Pacific slope and is of value only in the Rocky Mountain regions or in a mild climate.

\section{Russian Mulberry}

A very rapid-growing plant; bears well; fruit sweet, variable in size and color; leaf dark green and of very different shapes; some are birch-shaped, others cut and notched as much as any of our oaks, and in as many different shapes as all the varieties put together. Will stand almost any a mount of drought.

\section{Strawberry-Raspberry}

One of the remarkable recent introductions from Japan. A beautiful dwarf Raspberry, seeming to be a hybrid between the raspberry and strawberry. Fruit is early, stands well out from the foliage, size and shape of a strawberry; color, brilliant crimson. Most highly esteemed for its hardiness. The fruit is used principally in jams and jellies flavored with other fruits.

\section{Senator Dunlap Strawberry}

A well-tested, wonderfully productive variety, one of the safe sorts to plant everywhere and sure to take a high place among the prominent standard sorts. Plant resembles Warfield; rampant runner, should be restricted in its production of plants; fully equal to Crescent and Warfield in its ability to succeed under all circumstances. Fruit good size, regular form, beautiful bright red, glossy, firm; splendid keeper and shipper, excellent quality, one of the best for canning. Ripens early and continues a long time. It promises to stand at the head in its wonderful ability to ripen a good crop under almost any condition of drought or neglect.

This variety bears both pistils and stamens and therefore needs no fertilizer.

\section{Vegetables}

\section{Asparagus}

Columbian Mammoth White. This variety produces very large white shoots and is more valuable for canning than any other. It is a very rapid-growing plant.

Conover's Colossal. Shoots deep green and often over an inch in diameter are thrown up very rapidly from this variety. One of the best.

\section{Rhubarb, Linnaeus}

The very finest variety of Pie Plant; very large, early, tender and fine. 


\section{WEEPING TREES}

\section{Mountain Ash}

A pendulous weeper of irregular, rapid growth; sometimes planted in the center of small arbors and trained about them as a vine.

\section{Cut-leaved Birch}

Tree tall and slender, with pendulous branches. The bark of this tree is silvery white when tree is mature; foliage dark green, glossy and beautifully cut. We regard this as the most attractive of all upright-growing weeping trees. Have seen branches cut from this tree 5 feet long and only $\frac{1}{18}$ of an inch in diameter at the base. This tree will stand any kind of exposure; it is perfectly hardy.

\section{Willows}

Kilmarnock. A variety of the Goat Willow, or common Willow. Grafted 5 to 7 feet high upon the Comewell stock, it forms, without any training, an exceedingly graceful tree, with glossy foliage and perfect umbrella head; unique in form. Vigorous and thrives in all soils. Not quite hardy here.

Niobe. Perfectly hardy and very beautiful; a new golden variety introduced by Prof. Hansen, of South Dakota.

Wisconsin. The hardiest of all weeping Willows; grows very large, with long, slender, drooping shoots; a magnificent tree in the mountain region of the West.

\section{Camperdown Elm}

Grafted 6 to 8 feet high, this forms one of the most picturesque drooping trees. It is of rank growth; the shoots often making a zigzag growth outward and downward of several feet in a single season. The leaves are large and dark green, and cover the tree with a luxuriant mass of verdure.

\section{Teas' W'eeping Mulberry}

This tree is similar in general appearance and habit of growth to the Kilmarnock Weeping Willow, but it grows much more rapidly and the branches are more drooping. This variety will frequently grow from 5 to 6 feet in a season, and it is nothing uncommon to see the branches trailing on the ground. The leaf is of the same general form as the Russian Mulberry, of which it is a variety. We regard this as the hardiest of all dwarf weepers.

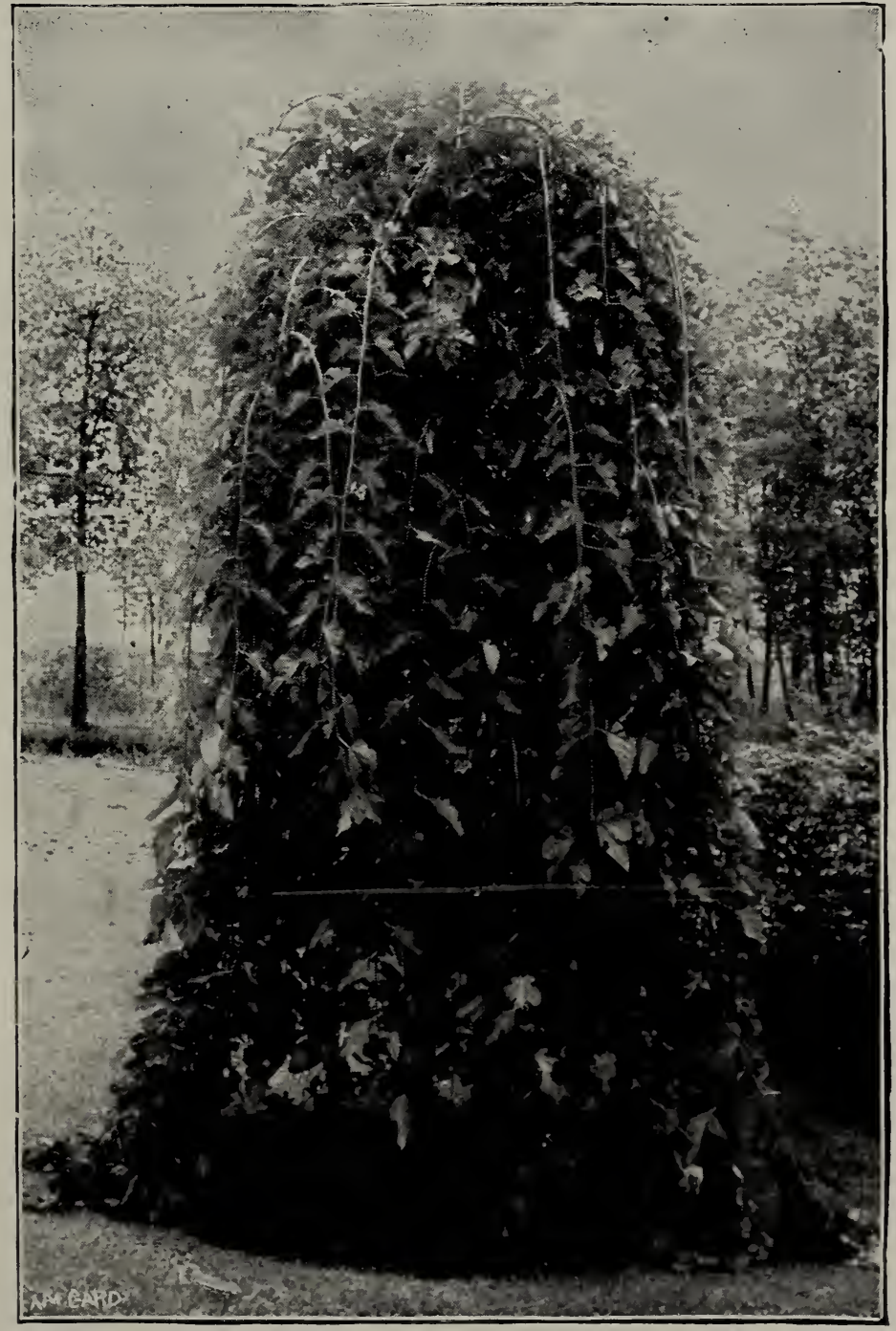

Teas' Weeping Mulberry 


\section{SHADE AND ORNAMENTAL TREES}

\section{Green Ash}

Known in the West as White Ash. A native tree of rather slow growth, but of hard, tough fiber. One of the best of timber trees. This tree thrives better than almost any other tree in dry sections, such as North and South Dakota.

\section{Basswood (American Linden)}

This is one of our strongest-growing native trees, and one of the most desirable trees we have for shade purposes. It grows rapidly to immense size, and forms a round, compact top; this, with its broad deep green leaves, makes a dense shade.

\section{European White Birch}

A rapid-growing tree, and when fully developed has snow-white bark. This tree is practically of the same form as the Cut-leaved Birch, but lacks the pendulous habit of the latter, and also its cut leaves. It is a very desirable tree.

\section{Catalpa speciosa}

A very rapid-growing tree, highly recommended for post timber; leaf heartshaped, light green and very large. Some specimens are not entirely hardy in this

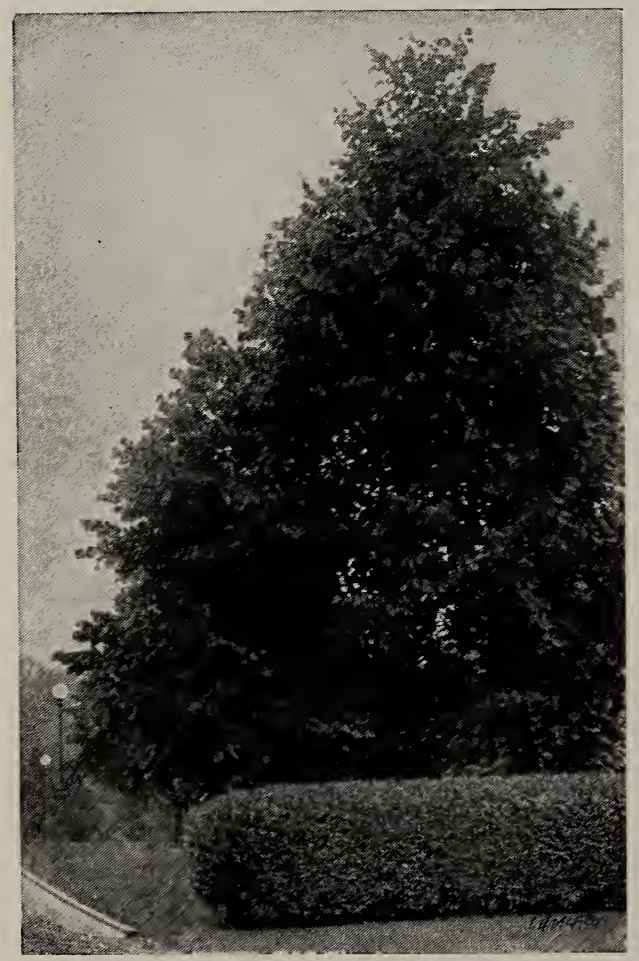

American Linden latitude. We consider that its principal value here is as an ornamental tree. It bears large trusses of beautiful flowers of light lilac color, sprinkled with brown; very fragrant.

\section{American Sweet Chestnut}

The nuts of this tree form quite an item in our commerce. Although smaller than some other sorts, they are sweeter and more delicately flavored. This Chestnut is also a grand timber and ornamental shade tree, spreading in midsummer, billowy masses of creamy, fragrant catkins above its large, deep green leaves, making a most beautiful specimen on the lawn.

\section{Hackberry}

A rare native tree with numerous slender branches which spread horizontally, and thick, rough bark; apple-like foliage, but more pointed and a bright shiny green; a very desirable tree for street planting.

\section{Horse-Chestnut}

This tree has an elegant pyramidal form, with large, deep-lobed leaves and showy upright panicles of red or white flowers. Tree hardy, vigorous and free from insect pests. This is among the first trees to unfold its leaves in spring.

\section{Black Cherry}

This is the common black Cherry of our forests. A tree of rapid growth. The lumber of this tree, we are told by parties well posted, is of more value than that of mahogany. It is a tree that should be much more cultivated than it is.

\section{Cottonwood}

A native tree of much value in the West.

\section{Box Elder}

A low-spreading tree of rapid growth, well adapted to dry and cold climates. One of the best trees for the Northwest.

\section{White Elm}

The native white or water Elm of our forests is too well known to require description. The most beautiful of all shade trees for this climate.

\section{Hop Tree, or Wafer Ash}

A small tree, seldom growing over I2 feet high; perfectly hardy; leaf threelobed, dark green and glossy; seed enclosed in a circular wing, which hang in clusters. It has a very peculiar strong hop smell. 


\section{European Larch}

This is one of the most rapid-growing of the coniferous trees, frequently making a growth of 3 or 4 feet in a year. The wood is hard, and when the trees are mature makes a very durable post timber. In Europe trees have been grown slowly. The timber has been used for piling along wharves, and has been known to have lasted for hundreds of years. This tree closely resembles the American Tamarack, but differs from it in being of more rapid growth, and cones of much larger size.

\section{Black Locust}

This is the common form of Locust grown through the central West. Rather a slow-growing, hard-wooded tree, with yellow or white flowers borne in long, pendulous racemes. Flowers fragrant, and the wood durable as post timber.

\section{Kentucky Coffee Tree}

A very ornamental, hardy tree of upright, rapid growth with rough bark and coarse branches; foliage of a bluish green color; flowers white followed by long pods. The name coffee tree comes from the fact of the seeds in the pods having been used by early settlers as a substitute for coffee.

\section{Magnolia acuminata \\ (Cucumber Magnolia)}

A beautiful pyramidal-growing tree, attaining from 60 to 90 feet in height. Leaves 6 to 9 inches long.

\section{Maple}

Hard (Sugar Maple). A well-known native tree, valuable both for the production of sugar and wood; very desirable as an ornamental shade tree.

Norway. A handsome tree, of fairly rapid growth, forming a dense, rounded head of strong branches and broad, deep green leaves. Sturdy, compact, vigorous. It is one of the very best trees for lawns, parks and gardens.

Soft, or Silver. The common soft Maple west of the Mississippi, with red bark.

Wier's Cut-leaved Silver. A variety of the Silver-leaved Maple, and one of the most remarkable of trees, with cut or dissected foliage. Its growth is rapid, shoots slender and drooping, giving it a habit almost as graceful as the Cut-leaved Birch. The foliage is abundant, silvery underneath, and on the young wood especially deeply and delicately cut. The leaf-stalks are long and tinted with red on the upper surface. Easily adapted to small places by an occasional cutting back, which it will bear to any degree.

\section{Mountain Ash}

American. A tree of coarser growth and foliage than the European, and producing larger and lighter colored berries.

European. A fine, hardy tree; head dense and regular; covered from July till winter with great clusters of scarlet berries.

Oak-leaved. A hardy tree of fine pyramidal habit. Foliage simple and deeply lobed, resembling the oak; bright green above and downy beneath. One of the finest lawn trees.

\section{Poplar}

Carolina. One of the most rapid-growing of our native shade trees. Leaves very large, deep green and glossy. Tree hardy and of much value where a quick screen or shade is wanted.

Russian. This tree closely resembles the Carolina Poplar, but is of slower growth, and is claimed by good authority to have no advantage over it.

Silver-leaf. This tree is valued highly in the dry sections of the Northwest, where it is found to be one of the most hardy of trees. The foliage is very dark on the upper side and silvery white beneath. The tree forms a dense top of moderate size. It is valuable for both shade and windbreak purposes.

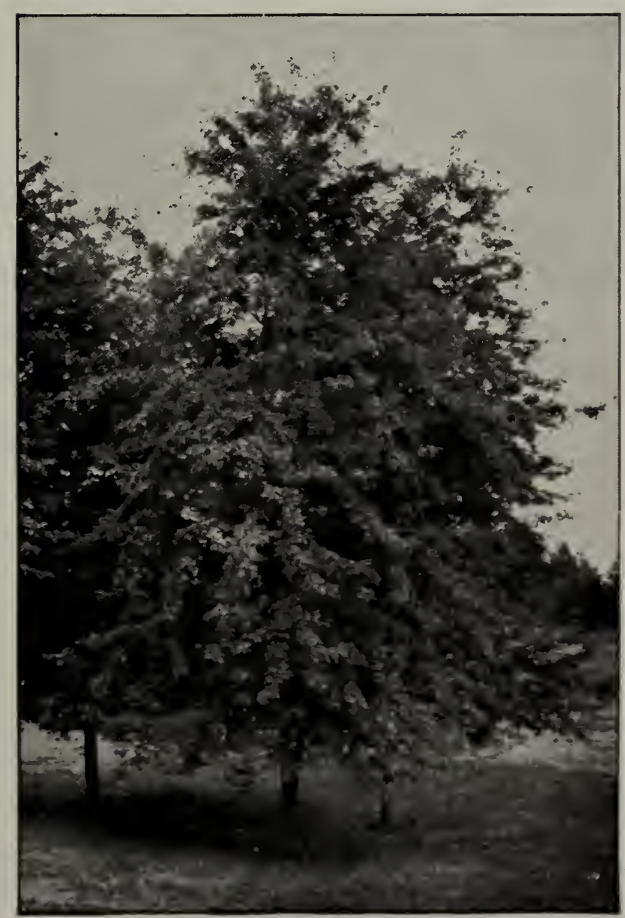

Silver Maple 


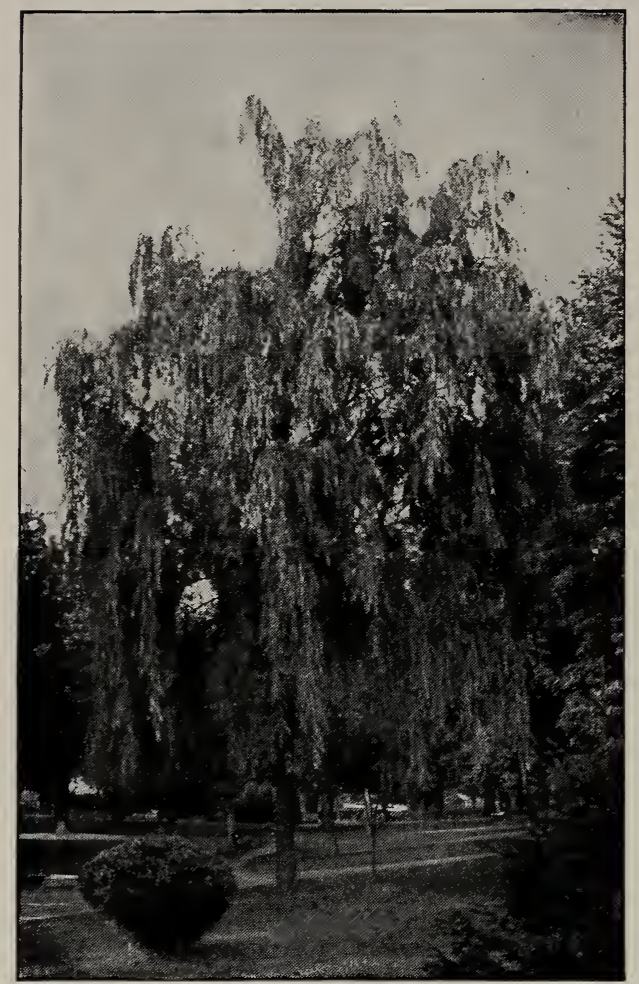

Weeping Willow

\section{Double-flowering Plum \\ (Prunus triloba)}

A native of China. The flowers resemble our Flowering Almond, but are much larger. The clusters of the flowers are also similar, but the tree grows much larger and is hardy.

\section{Tulip Tree}

A rapid-growing native tree of pyramidal form, resembling the hard maple, but with less rounded top. Flowers closely resemble the tulip; yellow in color, with deep orange at the base of petals, about 2 inches in length. It can hardly be classed as hardy in this latitude.

\section{Wild Crab}

This is our native Crab, Pyrus Coronaria. Tree seldom grows more than I2 feet high, with rounded top and bright pink blossoms.

\section{Willow}

Golden. A rapid-growing Willow, with bright yellow bark; very attractive where planted in masses for winter decoration.

Laurel-leaved. Leaves in color, texture and shape resembling the laurel. Tree round-topped and of rapid growth; perfectly hardy.

White. A fine tree for windbreaks and extensively planted in the North and Northwest. Leaves silky on under side. Trees sometimes attain a height of 80 feet, with a trunk 3 or 4 feet in diameter and ascending branches.

\section{EVERGREENS}

The only trouble in handling evergreens is allowing the roots to get dry. The sap of these trees is resinous, and if allowed to dry it hardens and closes the pores of the wood and thus stops the circulation and kills the tree. Very little exposure to hot sun or drying winds will sometimes do this. Great care should be taken in planting to keep goods from exposure to either sun or wind, and they must be kept moist.

\section{Arborvitae}

American, or White Cedar. This tree is very unique in its habits of growth, the leaf gradually hardening and forming the wood of the tree; habit uprigh $\hat{\imath}$; much inclined to branch and form more than one trunk; one of the best trees for ornamental hedging.

Globosa. Round, compact form and dense foliage. Foliage stands fan-shaped form around trunk; it is a beautiful tree.

Golden. Same form and habit as the American Arborvitæ, but with bright yellow foliage on new growth.

Pyramidal. A densely branched variety forming a perfect column; holds its shape without trimming or pruning; hardy, and will succeed anywhere the American Arborvitæ does; a very ornamental type for many kinds of planting.

\section{Cedar}

Colorado Silver. This variety is midway between our native Cedar and the Irish Juniper in form, but far more silvery than either. More beautiful in color than the Colorado Blue Spruce.

\section{Fir}

Balsam. Tree conical in form; foliage deep green on upper surface and silvery on lower surface. A very symmetrical tree and very beautiful while young, but inclined to shed its small branches and become scrubby and naked.

Concolor. A very beautiful species with silvery gray bark on the young branches; leaves long and beautifully silvered, arranged in double rows, equal in color and beauty to the Colorado Blue Spruce. The most beautiful of all Evergreens. 


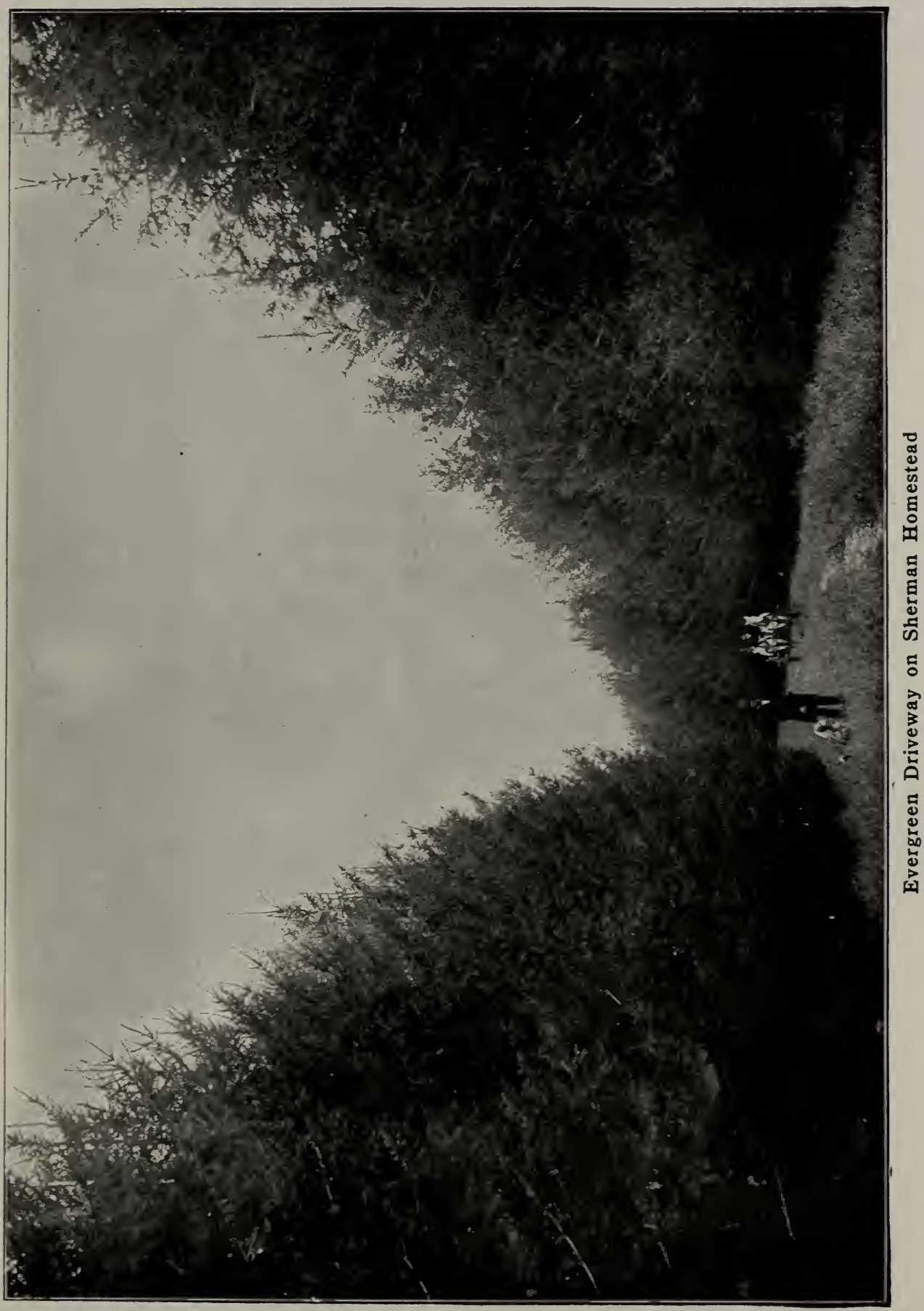




\section{Hemlock}

Sometimes called Weeping Spruce. This is the native Hemlock of the North and East. Where grown in sheltered places, there is nothing finer than this for a clipped hedge; it will not stand exposure, however, to dry winds of extreme temperature.

\section{Irish Juniper}

Foliage same as red cedar; top very narrow and symmetrical; color silvery green; one of the most beautiful of evergreens, but tender in this latitude and not recommended for planting in exposed situations.

\section{Pine}

Austrian. It is one of the best foreign species for this country. Its growth, even when young, is characteristically stout and sturdy. A remarkably robust, hardy, spreading tree of grand size; very dark and massive in effect, and when planted in an appropriate location is distinct and unique. One of the hardiest in dry sections.

Jack. The most northern of all American Pines; valued for its extreme hardiness and vigor; withstands long droughts and hot, dry winds; of rather irregular and shrubby growth; foliage bright green; needles short and stiff.

Mugho. This is the most beautiful of all dwarf Pines. It forms a low top with ascending branches, and the breadth of

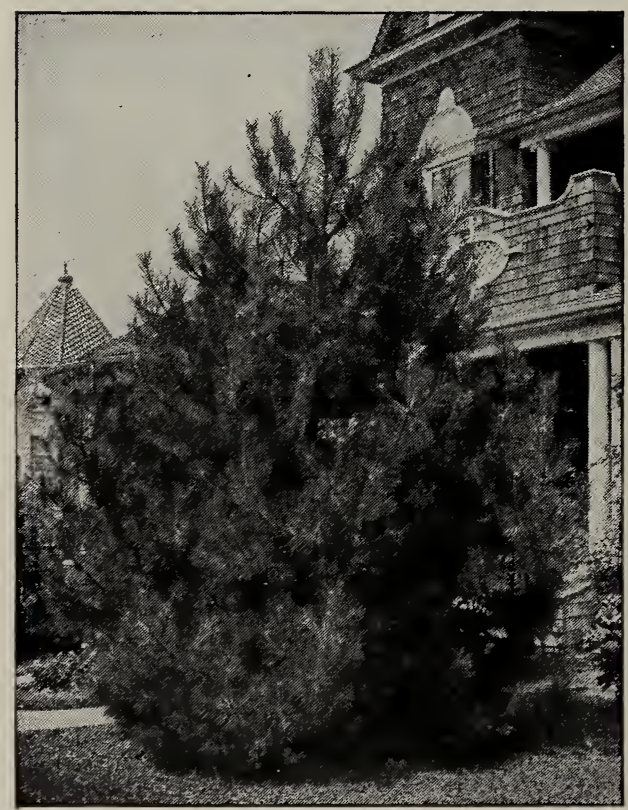

Ausțrian Pinẹ the tree is frequen tly double its height. Foliage bright green. A valuable tree for ornamental planting.

Ponderosa, or Bull Pine. A very rapidgrowing Pine of the Rocky Mountains. The leaves of this Pine are very long and silvery, hence the name. It is highly prized through some sections of Nebraska and Dakota where evergreens are hard to grow.

Scotch. One of the most rugged of all evergreens; a very rapid-growing tree and one which will stand almost any climate. We know of no tree that will compare with it for windbreak purposes on our open prairies.

White. A rapid, upright-growing tree; foliage fine and soft to the touch. The most ornamental of Pine trees and excelled by none for timber purposes. Not hardy in dry and wind-swept places.

\section{Spruce}

Black Hill. This is a western type of the American White Spruce, dwarfed by growing for centuries in the dry, arid climate of the Black Hills. It closely resembles the eastern type of the White Spruce, but is slower in growth, more compact in form and more silvery in color. It is one of the best of all of the evergreens for planting for ornamental purposes in dry, arid sections.

Colorado Blue. A slow-growing tree with branches broad and fan-shaped. This species varies greatly in color, from pale green to a beautiful silvery green. Specimens of the latter color are hard to obtain, and for that reason are very expensive.

Douglas. A native of Colorado; large conical form; branches spreading, horizontal; leaves light green above, silvery white below.

Engelmann's. Resembles the Colorado Blue Spruce in general effect; foliage coloring from bluish-green to steel-blue; needles are not so long and are more soft and flexible.

Norway. Conical in form; color bright green; foliage sharp-pointed. Stands crowding well; an excellent tree for windbreaks and ornamental purposes.

White. We consider this the most beautiful of all the Spruce family. In shape it differs but little from the balsam fir while young, but is broader at the base when large. The foliage is finer than that of the Norway Spruce and of a silvery green. Tree extremely hardy, of moderate growth, and holds its beauty longer than any other evergreen known to us. 


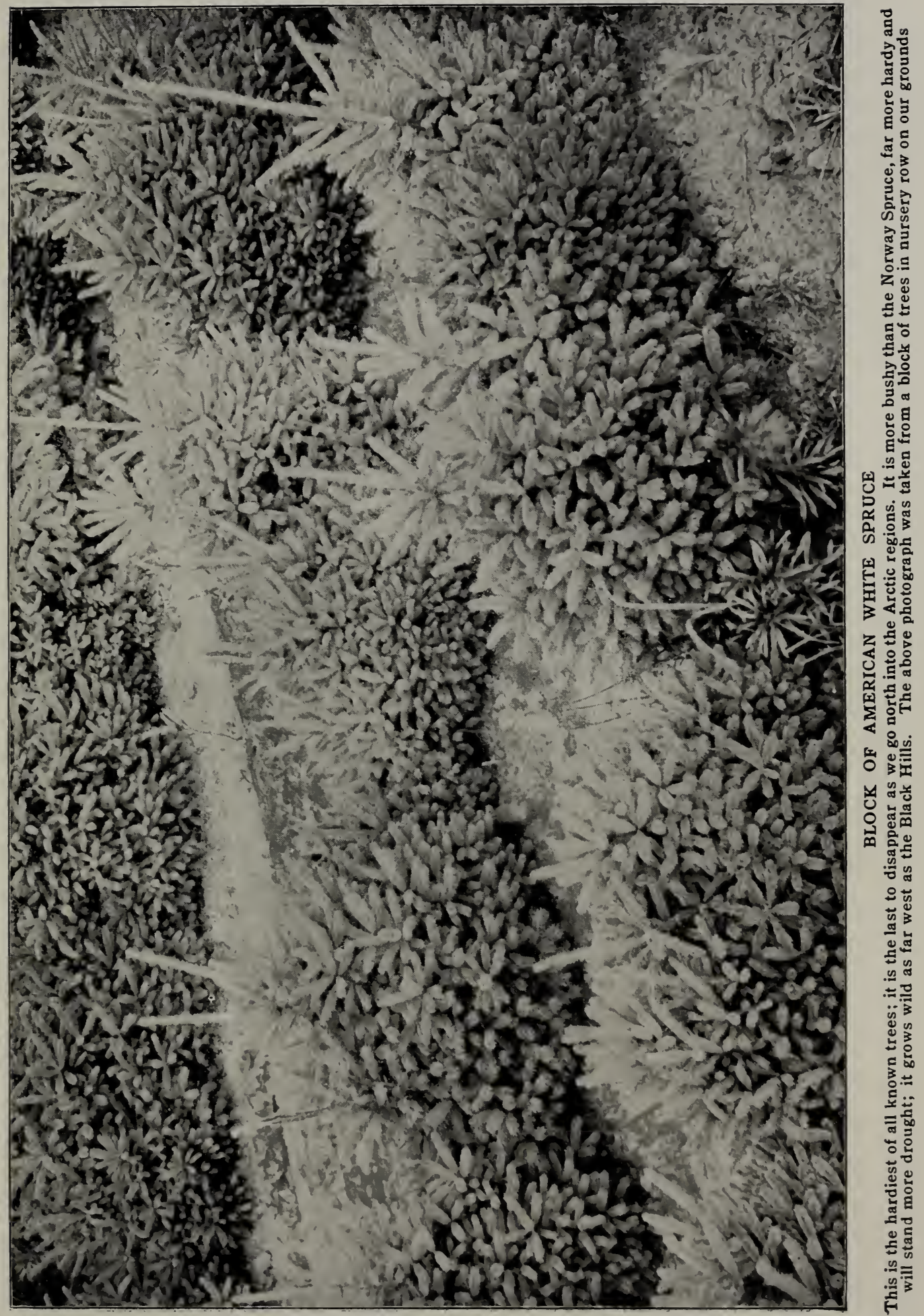




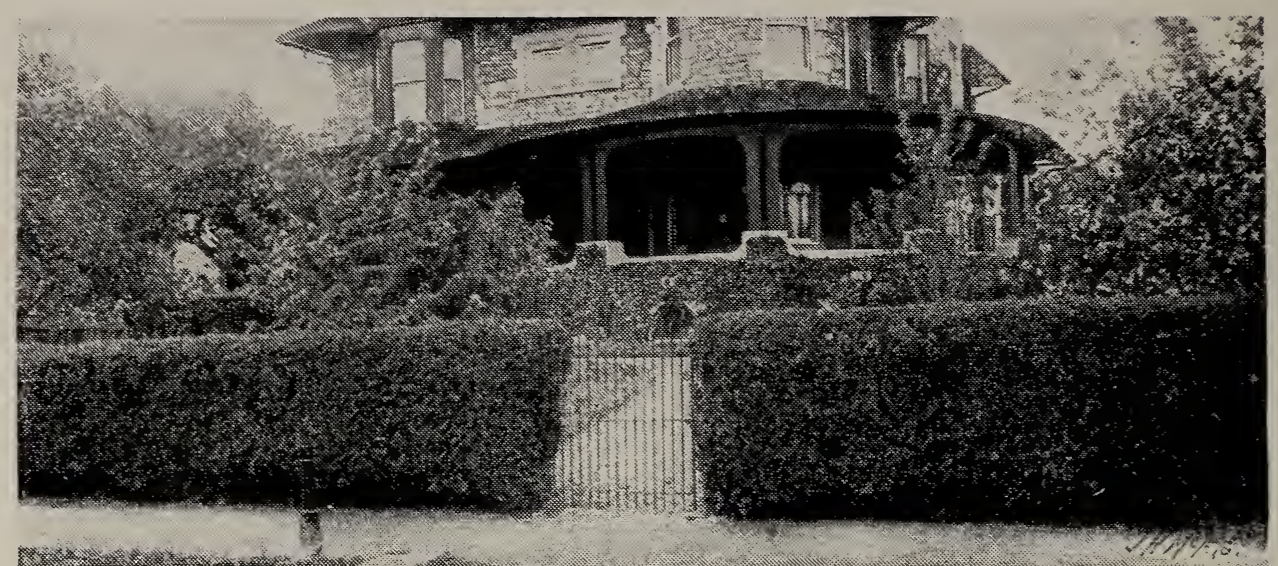

California Privet Hedge

\section{HEDGE PLANTS}

\section{Arborvitae}

For description, see Evergreens, page 28 .

\section{Barberry}

A perfectly hardy shrub, much used where a low-clipped hedge is wanted. The stalks are covered with three-pronged thorns; the framework of the leaf also terminates in thorns, which extend a little beyond the leaf. In June the shrub is loaded with very pretty, though small, yellow flowers, and in fall with bright red berries, which are very attractive. The fruit in quality much resembles the cranberry and is highly prized for jelly.

Purple-leaved. This variety is identical with the Barberry described above, with the exception of the color of the leaves and flowers. The leaves are dark purple and the flowers a purplish yellow. It is very hardy, and with a background of deep green is very effective for lawn decorations.

Thunberg's (B. Thimbergii). This variety is very unique, and forms a compact, round-headed shrub about 3 to $31 / 2$ feet high. The foliage is peculiar in form; branches very thorny. It is greatly admired.

\section{Buckthorn}

This, beyond question, is the hardiest of all our hedge plants. It is rather slow-growing; foliage very dark; blossoms white; fruit black; berries clinging to branches until late in the winter. For hedge purposes it should be kept clipped.

\section{Caragana (Siberian Pea Tree)}

A shrub or low tree with pea-shaped yellow flowers; hardy and useful for massing. Very valuable as a border hedge and hardy in the extreme North and Northwest.

\section{Elaeagnus angustifolia}

(Russian Olive)

This variety is better known in some sections as Russian Olive. The foliage is covered with white down, which gives the tree a white appearance when in full leaf. The blossoms are small and very fragrant, in fact so fragrant that the odor will frequently be detected even a quarter of a mile away. The berries are light silvery, dotted thickly with fine brown specks. This tree should be clipped for hedge purposes, as it grows to a moderate-sized tree if given its own course. It should be in every yard.

\section{Privet}

The use of Privet as a hedge plant is well-nigh universal. It takes kindly to the severe trimming necessary for this purpose.

California. A vigorous and hardy variety, with fine habit and foliage.

Regel's. A fine, hardy variety, desirable in growing singly as a specimen or in mass planting. This is one of the berry varieties.

\section{Honey Locust}

A magnificent shade tree, with compound leaves and long, deep brown seedpods, frequently ro or $\mathrm{I} 2$ inches in length. It is usually very thorny; thorns with two or more branches and from $I$ to 6 inches long.

\section{Osage Orange}

This is the common hedge plant of southern Illinois, Ohio and Missouri. Where kept thoroughly clipped it makes a good fence. 


\section{NUT-BEARING TREES}

\section{Butternut}

A most valuable nut tree; we have known them to bear at seven years from the seed. The nuts are long; kernel of a rich flavor. Plant in deep, moist soil for best results.

\section{Chestnut}

Sweet. See Shade and Ornamental Trees.

Horse. See shade and Ornamental Trees.

\section{Hazelnut}

The common native nut-bearing shrub of our woods.

\section{Hickory}

Bitter. This tree closely resembles the shellbark, but with a bitter nut instead of a sweet one. The wood also is less valuable.

Shellbark. In flavor and quality of kernel this is generally esteemed the choicest of our native nuts,- of all nuts, some experts have said. The tree is a handsome, stately shade tree, with tough white wood of great strength and elasticity. Marketable at high prices.

\section{Oak}

Pin. Almost pyramidal in habit, and sometimes described as half-weeping when old, because its lower branches touch the ground. It grows faster and develops the family characteristics earlier than most Oaks, as may be seen from some fine avenues planted within the last score of years. The leaves are deep green, glossy and finely divided. Orange-scarlet in fall.

Red. A large tree, unusually large in leaf and quick in growth. The young shoots and leaf-stems are red, the foliage purplish crimson in autumn. A most beautiful, majestic object on the lawn; acorns very large.

White. Grandest of its genus and of our American trees. A spreading, towering species, with rugged, massive trunk and branches. The deeply-lobed leaves change to dark crimson in fall.

\section{Black Walnut}

Too well known to need description. The lumber of this tree is becoming immensely valuable. We were informed by one of the leading furniture manufacturers of this state, a short time since, that the best grades of black walnut lumber could not be bought for less than $\$ 250$ per thousand feet.

\section{FLOWERING SHRUBS}

\section{Althea, or Rose of Sharon}

Double-flowering. There are many varieties of these plants with a great variety of habit. They belong to the Hibiscus family, and are not hardy in this section, except where well protected. They bloom very freely in August and September, and flowers vary much in color among the different varieties.

\section{Flowering Almond}

A low shrub with leaves similar in shape to our wild plum, but a little more pointed; flowers very double. We grow two kinds, one with red and the other with white flowers.

\section{Bechtel's Double-Flowering Crab}

Most beautiful of all the fine varieties of Flowering Crabs. At a distance the pretty medium-sized tree seems to be covered with dainty little roses of a delicate pink color. Blooms when quite young. Is very fragrant. This is a variety of our native wild Crab, Pyrus coronaria Ionensis.

\section{Barberry}

Purple-leaved. See Hedge Plants.

Thunberg's. See Hedge Plants.

\section{Buffalo Berry}

A native shrub in the dry sections of both North and South Dakota, and it is also found throughout the Rocky mountains from Canada to Mexico. The flowers are small and yellow. The berries are a bright red and very sour. The leaves are a downy white on both sides. A peculiar shrub and should be much more grown than it is for ornamental purposes.

\section{Calycanthus floridus \\ (Caroline Allspice, Sweet Shrub)}

This unique shrub grows rapidly upright, clothing its straight, strong, reddish brown shoots with large, glossy leaves, from the axils of which spring odd, double, spicily fragrant flowers of chocolate-red. The wood also has a peculiar fragrance. It is a hardy native shrub that deserves much wider planting. 


\section{Cornus}

Sanguinea. The leaves are elegantly marked with white, contrasting finely with the deep blood-red bark; hardy.

Red-Branched. (Dogwood.) A rare and remarkable variety with bright red bark in winter.

\section{High-Bush Cranberry}

We have been trying for years past to save from total destruction some of our native shrubs and plants. Among these we class the High-Bush Cranberry as one of the most desirable. It resembles the snowball, both in form of plant and leaf. This shrub will grow to a height of from 8 to I $_{5}$ feet, and is not troubled with insect pests. It is most highly appreciated in winter when it is covered with large clusters of scarlet berries, which, if not disturbed, will hang on until spring. The fruit is prized by many for the brilliantly colored and highly flavored jelly which is made from the berries. The shrub is perfectly hardy. It succeeds best in a moist, rich soil.

\section{Double-flowering Currant}

An American species, with deep red flowers, produced in great abundance in early spring.

\section{Deutzia}

D. crenata. The beautiful white singleflowered species that is a mass of bloom in early June. Often preferred to the double sorts.

D. crenata fl. pl. A double form of the type. Handsome and effective. White flowers, delicately flushed with pink.

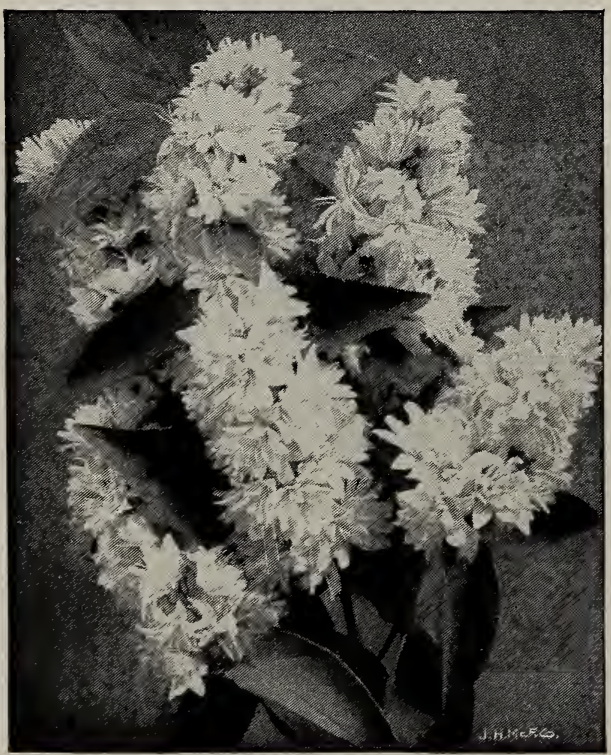

Deutzia crenata
Deutzia crenata, Pride of Rochester. A showy early and large-flowering sort that blooms in May before the others. The flowers are large, double, white, tinted with rose on the outer edges.

D. gracilis. Slender-branched Deutzia. A neat, dense little bush of low habit, that blooms in May, wreathing its drooping branches with pure white flowers. Equally valuable for shrubberies and forcing.

\section{Cut-Leaved Elder}

The leaves of this variety are fern-like in formation, and the shrub is of halfdrooping habit. One of the finest in cultivation, being especially effective in masses.

\section{See Hedge Plants.}

\section{Elaeagnus}

\section{Euonymus}

(Wahoo, or Strawberry Tree)

One of our native shrubs; it seldom grows over 6 feet high; symmetrical; leaves oblong, dark green and glossy; fruit similar to bittersweet.

\section{Fringe}

Purple. Smoke Tree. From the south of Europe. Much-admired shrub for its curious fringe, or hair-like flowers, that covers the whole surface of the plant in midsummer.

White. This shrub belongs to the Ash family; is very slow-growing and perfectly hardy. Blossoms white, with long, narrow petals, giving the shrub a fringe-like appearance when in full bloom. The leaves are very large and glossy. A very desirable shrub.

\section{Tartarian Honeysuckle}

A woody, upright-growing shrub, with pink flowers and deep green leaves; blossoms in June; blooms profusely.

\section{Hydrangea paniculata grandiflora}

Very hardy; grows from 6 to ro feet high; loaded in August and September with large spikes of flowers, ranging in size from 6 to 12 inches; color white.

\section{Tree-form Hydrangea}

Same as above, except that it is grown in standard or tree form.

\section{Lilac}

White. The common white Lilac.

Purple. Also very common.

Persian. A native of Persia; rather a small plant, seldom growing over 6 feet; foliage small; flowers bright purple. A profuse bloomer. 


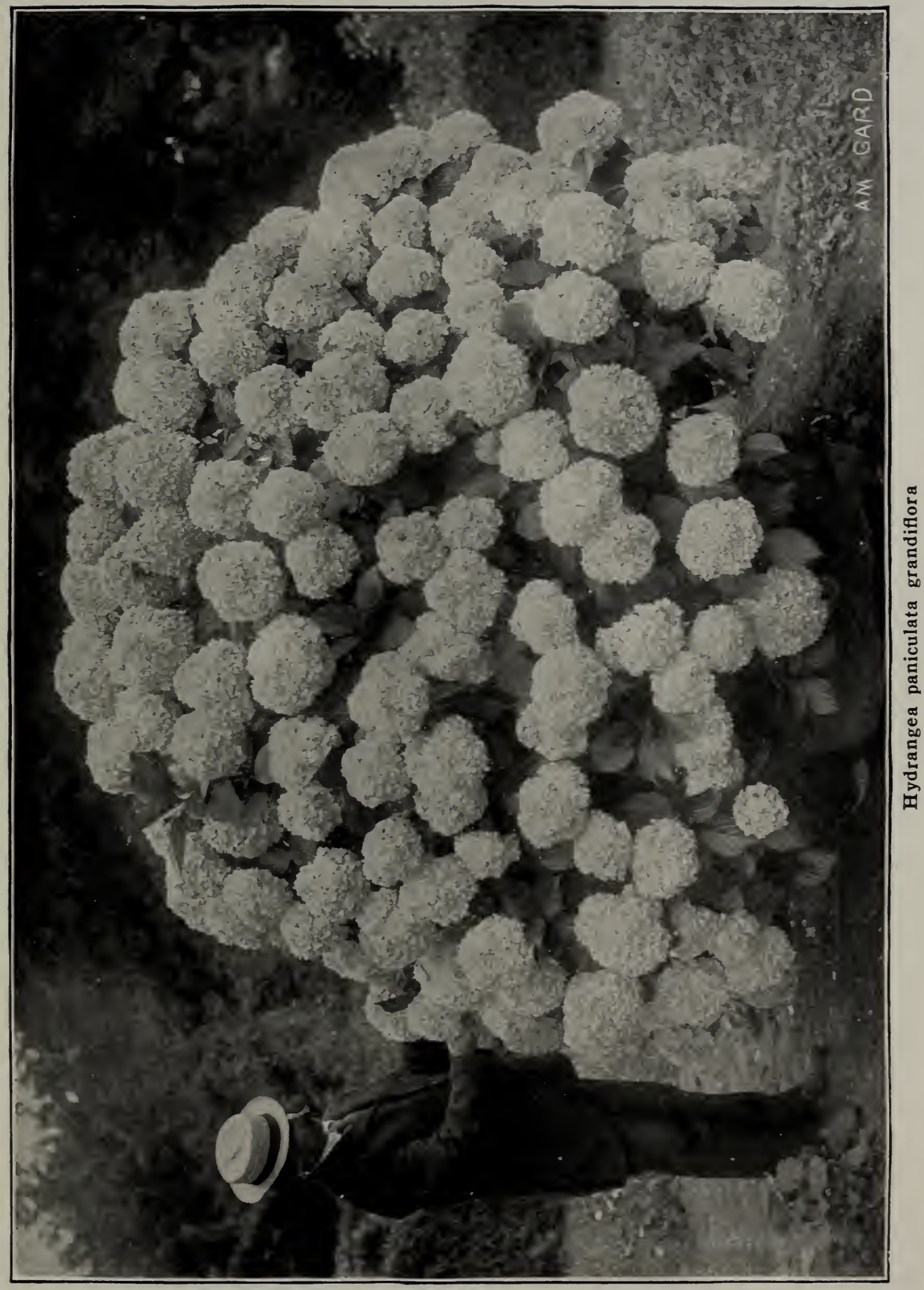




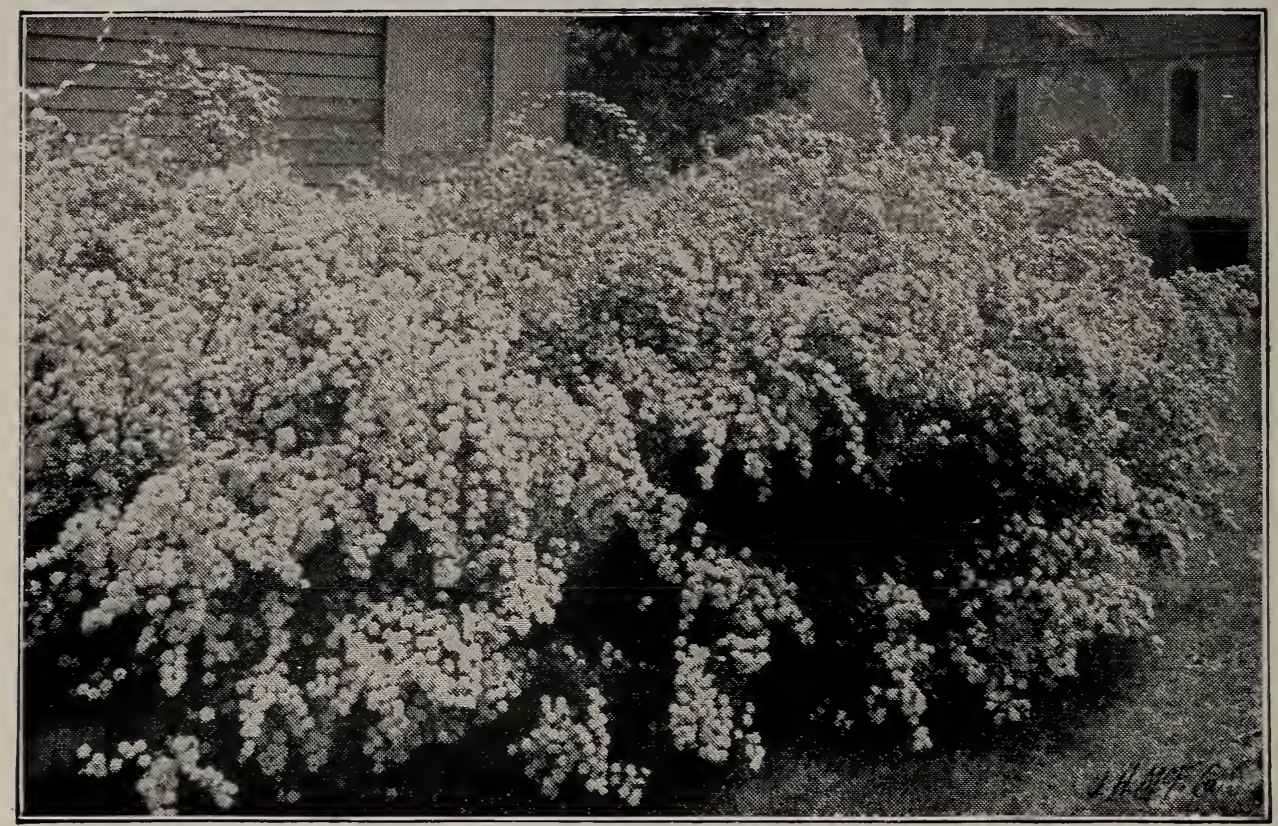

Spiræa Van Houttei

Lilac, continued

M. Buchner. Plant dwarf; panicle erect and very large; very double, color pale lilac; distinct and fine.

Villosa. A new Japanese variety; flowers small, but borne in large clusters. Light purple in bud, white when open. Foliage large and shaped like a plum leaf. This shrub is principally valued for its late flowering, coming some three weeks after the other lilacs, and for the fragrance of its flowers, which is peculiar and very penetrating.

\section{Japan Tree Lilac}

A species from Japan. Leaves thick, pointed, leathery and dark; flowers in very large panicles; creamy white and privetlike. Makes a small tree and is desirable because of its distinct foliage and late blooming, and tree form.

\section{Double-Flowering Plum (Prunus triloba)}

A native of China. The flowers resemble our Flowering Almond, but are much larger. The clustering of the flowers is also similar, but the tree grows much larger and is hardy.

\section{Prunus Pissardi}

One of the best and finest purple-leaved small trees or shrubs; foliage and young shoots are of a rich reddish purple, which they retain throughout the season; flowers small, white, single, covering the tree.

\section{Japan Quince}

Has bright scarlet-crimson flowers in great profusion in the early spring. One of the best shrubs in the Catalogue. Not quite hardy here.

\section{Japan Snowball}

Of better habit than the familiar older form, with handsome plicate leaves and more delicately formed; whiter flowers.

\section{Snowball}

A well-known favorite shrub of large size, with globular clusters of pure white, sterile flowers the latter part of May.

\section{Snowberry}

A slow-growing plant, covered in the latter part of the summer and early fall with white berries about $3 / 8$ inch in diameter. Perfectly hardy.

\section{Spiræa}

Billardi. Rose-colored flowers in spikes. In bloom nearly all summer.

Van Houttei. A beautiful shrub, growing 4 to 6 feet high. Blossoms in clusters about $I \frac{1}{2}$ to 2 inches in diameter; flowers white and borne in great profusion, frequently covering the plant when in bloom. It is one of the finest shrubs we have for cemetery use, and also makes a beautiful ornamental hedge. It is perfectly hardy as far north as northern Minnesota. 


\section{Spiræa, continued}

Anthony Waterer. Dwarfish shrub, seldom growing more than 2 feet high. Flowers bright rose color, and borne in great profusion. It begins blooming in June and continues until frost kills the flowers. Very desirable for a border plant.

Aurea. The principal value of this shrub comes from the color of its foliage. It is the most desirable yellow-leaved plant for this latitude. Blossoms white and borne in flat clusters about 2 inches in diameter.

\section{Staghorr Sumac}

A large shrub or small tree, sometimes growing to the height of 20 feet. This differs from the common Sumac in that the wood is covered with a fine thorny substance closely resembling the moss on the horns of a stag soon after molting. hence the name.

\section{Syringa, or Mock Orange}

A vigorous-growing, hardy shrub, from 6 to Io feet high; blossoms pure white; a very profuse bloomer; have seen this shrub I 2 feet high, so loaded with bloom that its branches were bent to the ground; leaf large and dark green.

Garland Syringa. Very similar to the Syringa, or Mock Orange, but a stronger plant, and flowers nearly twice as large; have seen them measure $21 / 2$ inches in diameter. Blossoms in early summer.

Grandiflorus. Has very showy, large flowers, often 3 inches in diameter. Branches long and frequently loaded to the ground with weight of flowers.

Lemoine. A small shrub rarely attaining a height of more than four feet. Branches slender and bearing in June a profusion of flowers closely resembling the orange blossoms in size, form and fragrance, which is very desirable.

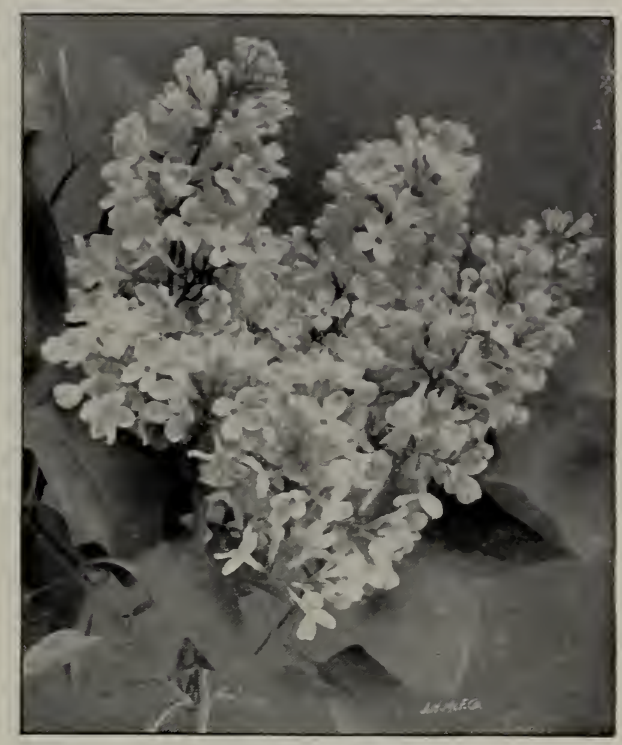

\section{Common Lilac}

\section{Tamarix}

Graceful shrubs with feathery foliage and large panicles of showy pink flowers. Relatively hardy. A moist, loamy soil is best for them.

\section{Weigela rosea}

An elegant shrub, with fine rose-colored flowers. Introduced from China by $\mathrm{Mr}$. Fortune, and considered one of the finest plants he has discovered. Of erect, compact growth; blossoms in June.

\section{White Thorn}

A small native tree, with flat-topped white flowers and red fruit. It was originally quite common in this section, but is now almost extinct. Very desirable where a small tree is wanted.

\section{Roses}

All Roses in this latitude need winter protection, and in this list where Roses a re classed as hardy, we mean hardy with winter protection.

African Black, or Black Prince. A moderate-growing, hardy, profuse-blooming plant; flowers very dark purplish red, almost black.

American Beauty. Large globular; deep pink, shaded with carmine; delicious odor; especially desirable for forcing.

Baby Rambler. A most attractive novelty in hardy Roses. The round, bushy Baby Rambler tops at all times a perfect mass of crimson bloom. The most florescent of all the Tree Roses.
Baron de Bonstettin. A fine Rose, velvety maroon in color, shaded with deep crimson.

Baltimore Belle. A climbing Rose, a little more slender in habit than Prairie Queen; flowers freely; color light pink. fading to white. A very beautiful and fragrant Climbing Rose.

Blanche Moreau (White Moss). One of the remontant type of Roses, white in color, and very desirable. One of the best of perpetual white moss Roses. 


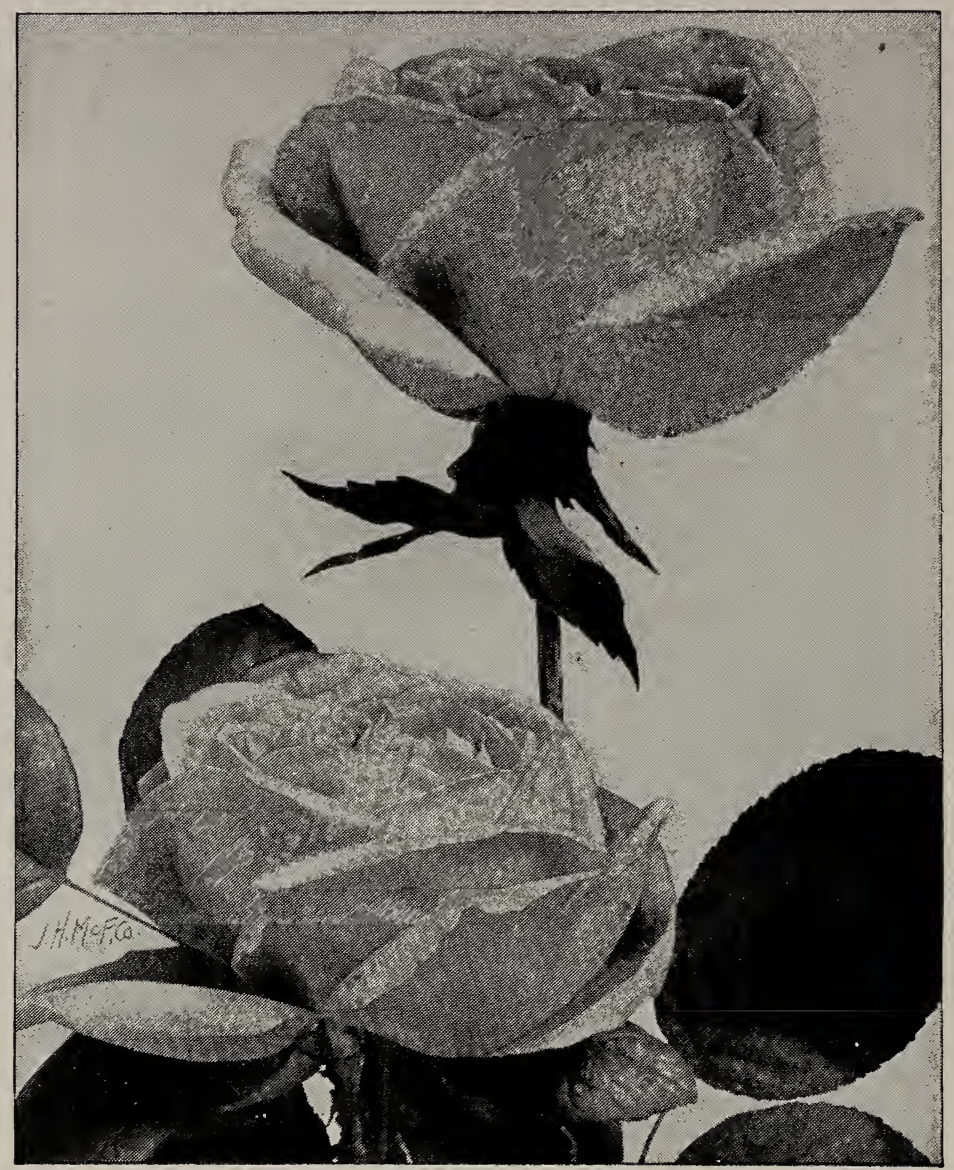

American Beauty Roses

ROSES, continued

The Bride. Most beautiful of the white Tea Roses, and forced in numberless quantities every year. The great, solid flowers remain perfect long after cutting; the stems are long and stiff, the foliage large and glossy; tender.

Bridesmaid. Clear bright pink, of an exquisite shade. Grown chiefly for its large, solid and handsome buds; the stems are good; the foliage glossy. Excellent also for bedding. Not hardy in this latitude.

Crimson Rambler. The famous crimsonclustered climber, so extremely effective when grown on pillars and trellises. The plant is a vigorous grower, making shoots 8 to Io feet long in a season. The foliage is large and glossy; the plant looks like a mass of double crimson flowers when in bloom. The panicles are large and remain perfect for several weeks. Hardy any where.

Coquette des Alpes. A free-blooming Rose of medium size; white, tinged with pale rose. Exceedingly dainty and attractive.

Clothilde Soupert. A grand free-flowering Rose; fine for bedding out or pot culture. The flowers are very double and handsomely formed, borne in sprays Outer petals pearl-white, shading to a center of rosy pink.

Crested Moss. Deep pink-colored buds, surrounded with a mossy fringe and crest; free from mildew. A fragrant, very beautiful Rose.

Dorothy Perkins. Of the same strong habit of growth as the Crimson Rambler. Large for a Rose of this class, very double, of a beautiful shell-pink color; sweetly scented, and borne in clusters of thirty or forty. One of the best.

Duke of Edinburgh. A seedling of General Jacqueminot; large, double flowers with little fragrance, bright crimson in color; foliage large and attractive. Blossoms very early in the season. A handsome Rose. 


\section{ROSES, continued}

General Jacqueminot. A probable seedling from the Hybrid China, Gloire des Rosamanes. Brilliant crimson; not full, but large and extremely effective; fragrant and of excellent hardy habit; forces well.

Gem of the Prairie. A cross between Prairie Queen and Hybrid Perpetual; a half climber and hardy; a little lighter than Prairie Queen, and very beautiful; blooms freely.

Harrison's Yellow. The old yellow Scotch Rose, well known by all; very hardy and a profuse bloomer.

John Hopper. A seedling from Jules Margottin, fertilized by Mme. Vidot. Bright rose with carmine center; large and full. A profuse bloomer; standard sort; hardy.

Killarney. Color flesh, shaded white, suffused pale pink flowers; large buds, long and pointed, and blooms profusely throughout the season.

Madame Charles Wood. Brilliant red; large and full; of fine form; a fine autumn bloomer.

Magna Charta. A hybrid that is very fine early in the season; color bright rose; large and full.

Marshail P. Wilder. Raised from the seed of General Jacqueminot. It is of vigorous growth, with healthy foliage; flowers large, semi-globular, full, well formed; color cherry-carmine, much like a light-colored Marie Baumann, or a shade deeper than Marie Rady, and very fragrant. In wood, foliage and form of flower it resembles Alfred Colomb, but the seedling excels that famous variety in vigor, hardiness and freedom of bloom. It continues to bloom profusely long after the other remontants are out of flower. In brief, it may be described as an improved Alfred Colomb, and as good a Rose as has been raised by any one. It is undoubtedly the finest of its color.

Mrs. John Laing. An exceptionally handsome and free-blooming Rose, of vigorous growth and fine habit. The color is a soft and delicate shade of pink; the flower is large and well formed, very fragrant and produced on good stems. A variety of especial value, as it blooms continuously in the open ground, and is also excellent for forcing, the buds selling at high prices.

Madame Plantier. One of the hardiest of white Roses and a rank-growing plant; a profuse bloomer; flowers medium size.

Paul Neyron. The largest Rose in cultivation, sometimes called the Peony Rose; color bright, fresh cerise-red. The plant makes a strong, healthy growth, and has clean, glossy foliage; blooms almost without intermission from June until late October.

Pink Moss. Deep pink buds, surrounded with delicate fringe-like moss. The most beautiful of all the Moss Roses.

Perle des Jardins. Probably better known than any other yellow Rose grown. Beautiful clear yellow, distinct from all other Tea Roses. Very double.

Prince Camille de Rohan. A velvety, blackish crimson Rose, of deep distinct shade; large, full, very handsome.

Prairie Queen. A well-known and much admired climbing Rose; a rank grower and profuse bloomer; flowers large, double and red. Have known plants of this variety to have over a thousand blossoms on at one time. Probably the best climbing Rose for this latitude.

Red Moss. Stalks, flowers and buds covered with fine thorns, much resembling moss.

Richmond. An exceptionally clean and strong-growing variety, requiring only ordinary care and treatment, producing uniformly long, fine flower stems. The flowers are borne freely - as free as Bride, Bridesmaid, Golden Gate and other old standbys-lasting in quality, beautifully

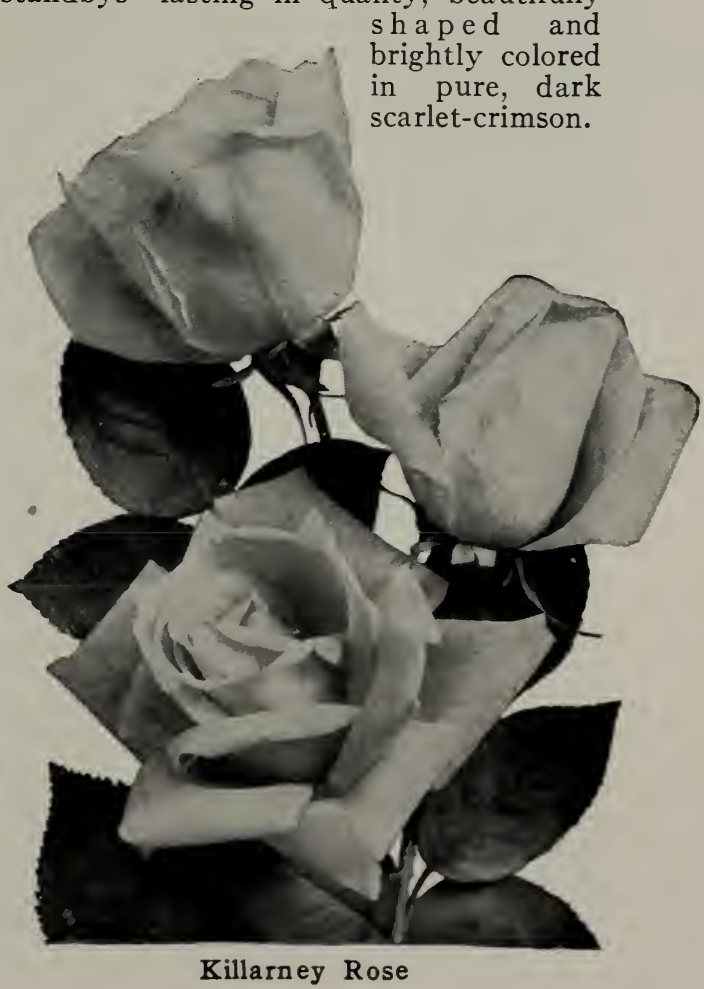




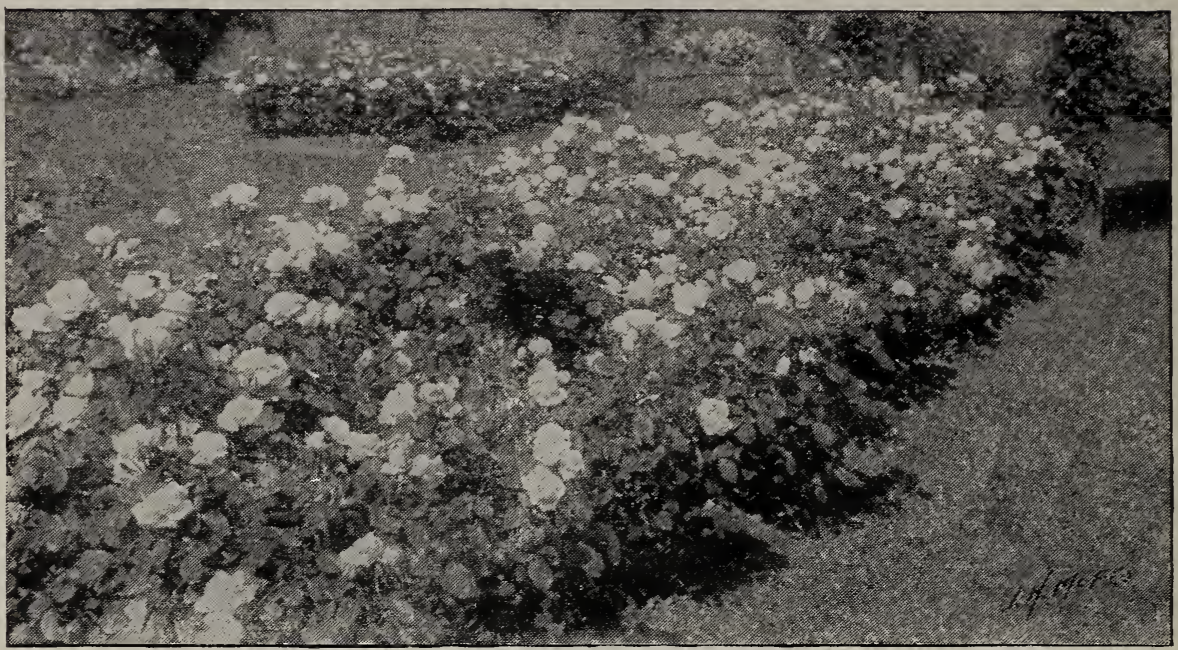

A Garden of Hardy Roses

\section{ROSES, continued}

Rosa rugosa. Hardiest of all Roses. This Japanese Rose forms a sturdy bush, 2 to 3 feet high, covered with large, dark green, glossy foliage, crowned with terminal clusters of Io to 20 flowers, each 3

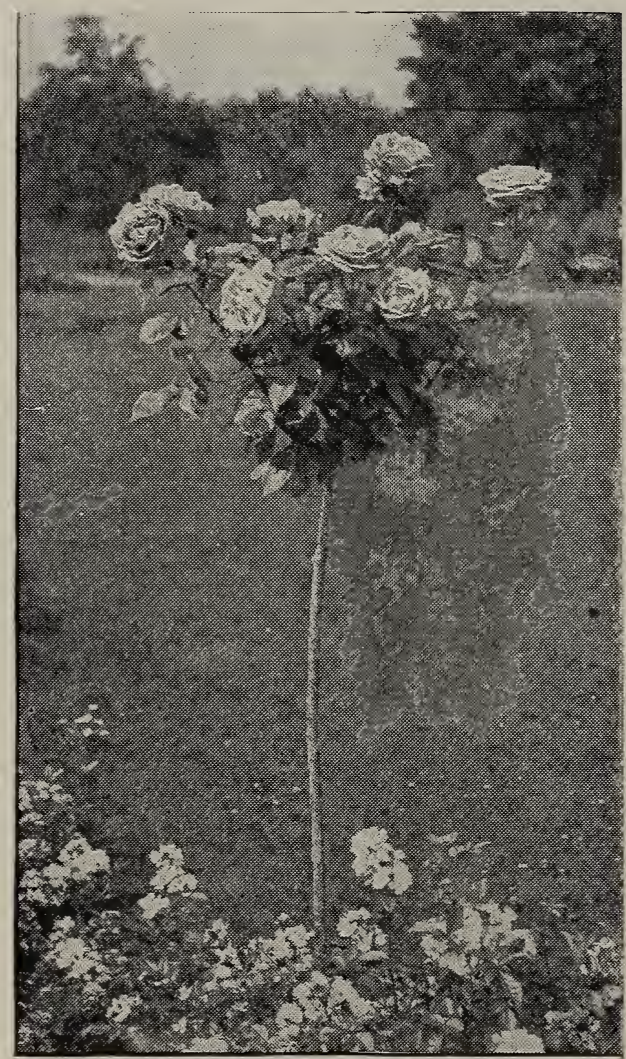

Tree Rose inches in diameter. Perfectly hardy. A valuable plant for the hardy border, or shrubberies, its large, handsome, scarlet fruits being very ornamental all through the autumn and early winter months. It also makes a splendid hedge, its foliage being impervious to the attacks of insects of all kinds.

Rosa rugosa alba. Same as above, except in color.

Seven Sisters. Named from clusters of flowers which it bears; flowers mediumsize, light rose color, double. A climbing Rose of medium growth.

Vick's Caprice. A novel striped Rose, with ground-color of soft satiny pink; distinctly marked with white and carmine. It is large and full, with beautiful long buds that show the stripes to advantage.

Victor Verdier. Bright rose, with carmine center, a very fresh shade of color; not fragrant; free-bloomer; wood very nearly smooth.

White Moss (Blanche Moreau). Same as red moss, except in color.

White Rambler (Thalia). Similar to the Yellow Rambler in every way except color, which is pure white.

\section{Tree Roses}

The Tree Roses are grafted on hardy Rose stalks 4 to 5 feet high, and when in full bloom are objects of beauty, making handsome plants for the lawn or Rose border. Fine, strong trees, that will bloom nicely the first year. 


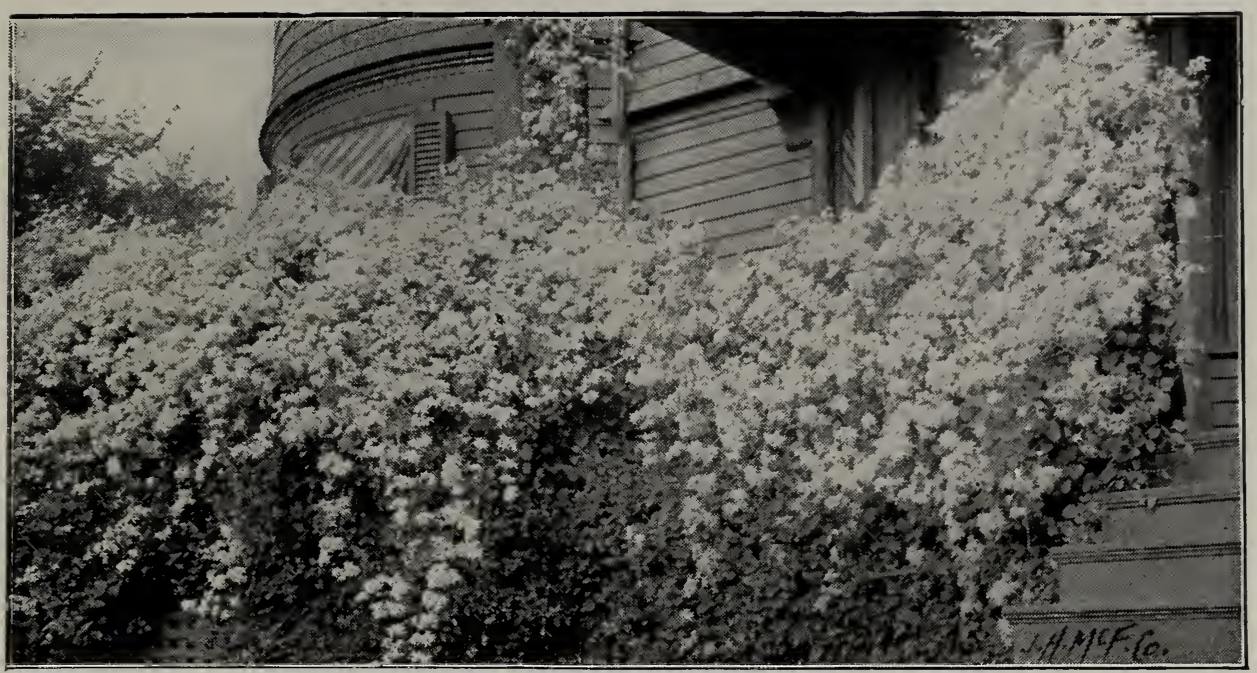

Clematis paniculata

\section{Vines}

\section{Ampelopsis}

Engelmanni. A clinging form of American Ivy, but shorter jointed than Quinquefolia. A rapid grower, often climbing ro feet in a single season. The best vine known for covering stone or brick work.

A. Quinquefolia( American Ivy, or Virginia Creeper). The common Fiveleaved Ivy, or Virginia Creeper.

Veitchii. Japan Creeper; Boston Ivy. Leaves smaller than those of the American, and overlap one another, forming a dense sheet of green. The plant is a little tender while young, and requires protection the first winter; but once established there is no further risk. It grows rapidly and clings to wall or fence with the tenacity of ivy; the foliage is very handsome in summer, and changes to crimson-scarlet in autumn. For covering walls, stumps of trees, rockeries, etc., no plant is so useful. For the ornamentation of brick and stone structures, it can be specially recommended.

\section{Bittersweet}

A twining vine of very rapid growth; waxy green, singlelobed leaves; bright scarlet berries. Perfectly hardy and very beautiful.

\section{Clematis}

Paniculata. A great novelty from Japan, It has proved to be one of the most desirable, useful and beautiful of hardy vines, being a luxuriant grower, profuse bloomer, and possessing fine foliage. It is particularly useful for covering verandas, pillars and fences, where a trellis or support can be provided for it to climb on. The flowers are of medium size, very pretty and fragrant, and produced in greatest profusion

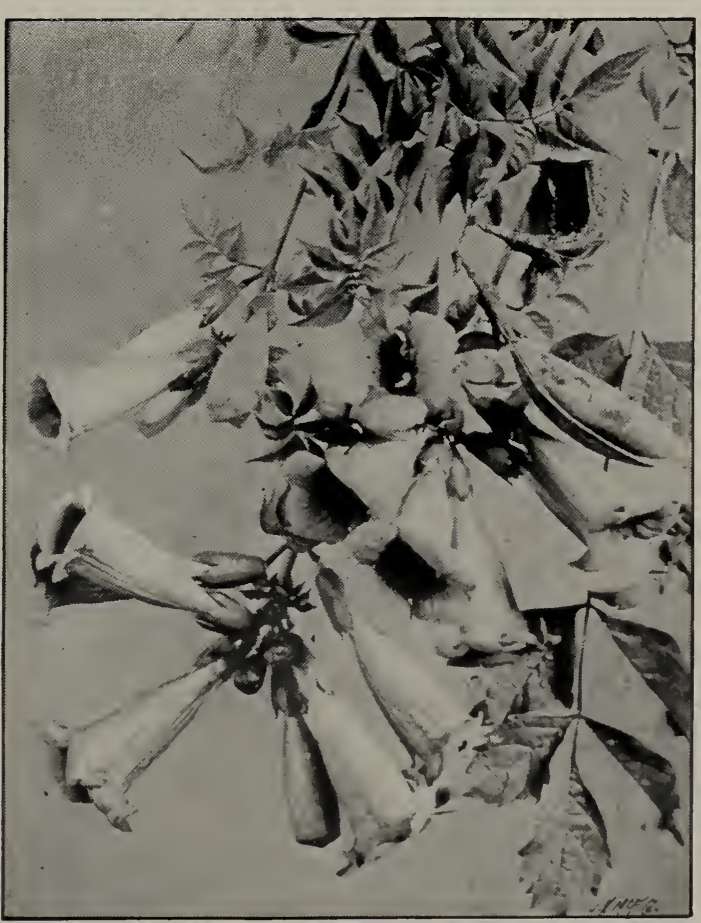

Trumpet Flowers (see page 42 ) 
Clematis, continued

in late summer. We can recommend this novelty in the strongest manner as one of the best vines to grow near the house. It makes a growth of from 25 to 30 feet in a single season, and should be cut back to the ground each spring.

C. Virginica. A remarkably vigcr us plant, and one of the finest for covering arbors, porches, and the like. This vine has been known to grow at the rate of 3 inches per day, and frequently makes a growth of 20 feet in a season. It is perfectly hardy. Flowers small, greenish white, and seed-pods very conspicuous and light gray in color.

C. coccinea. Small, bright coral-red; inverted bell-shaped; open but little. Very peculiar. Hardy and attractive.

C. Jackmani. Large, intense violetpurple; remarkable for its velvety richness; free in its growth and an abundant and successive bloomer.

C. Jackmani alba. Differs from above in color of flower, which is a clear white; the vine is a more slender grower.

\section{Dutchman's Pipe (Aristolochia Sipho)}

A magnificent hardy vine of rapid growth, with very large, heart-shaped leaves and brownish flowers, resembling in shape a miniature pipe.

\section{Trumpet Honeysuckle}

One of the most desirable of our native twining plants. Foliage glossy and a little on the sage-green order Flowers trumpet-shaped, about $\mathrm{I} / 2$ inches long, with a salmon shade, with red on the inner side of trumpet. Flowers borne in clusters, and continue all summer.

\section{Chinese Matrimony Vine}

Sometimes trained as a shrub. Purpleflowered and showy-fruited. Extra-vigorous in growth, bearing prodigious crops of large scarlet berries.

\section{Moonseed}

A native $t$ wining vine, of very rapid growth, with large deep green glossy leaves, closely resembling the English Ivy. The seed-pods are shaped like a new moon, hence the name. For covering stumps, stones or any low object, we know of no finer vine.

\section{Trumpet Flower (Bignonia radicans)}

A vine closely resembling the Wistaria. Flowers borne in small clusters; blossoms 2 inches in length by $3 / 4$ inch in diameter. Very showy, but not quite hardy enough for our climate here. Needs good protection over winter.

\section{Wistaria}

Purple. One of the most attractive and rapid-growing of all climbing plants; attains an immense size. Has long, pendulous clusters of dark blue flowers in May and June and in autumn.

White American. The flowers are clear white; bunches short; free bloomer.

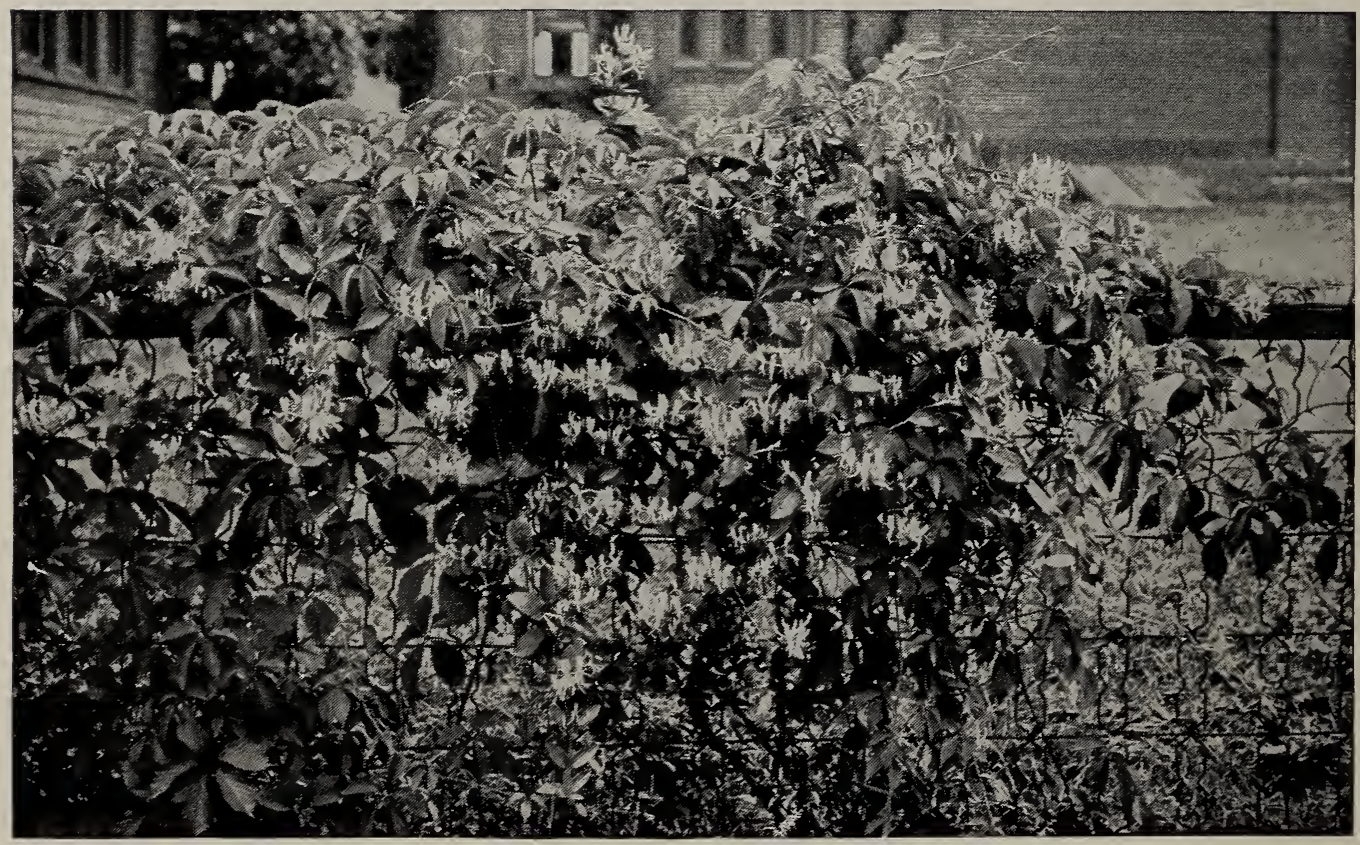

Trumpet Honeysuckle 


\section{Bulbs}

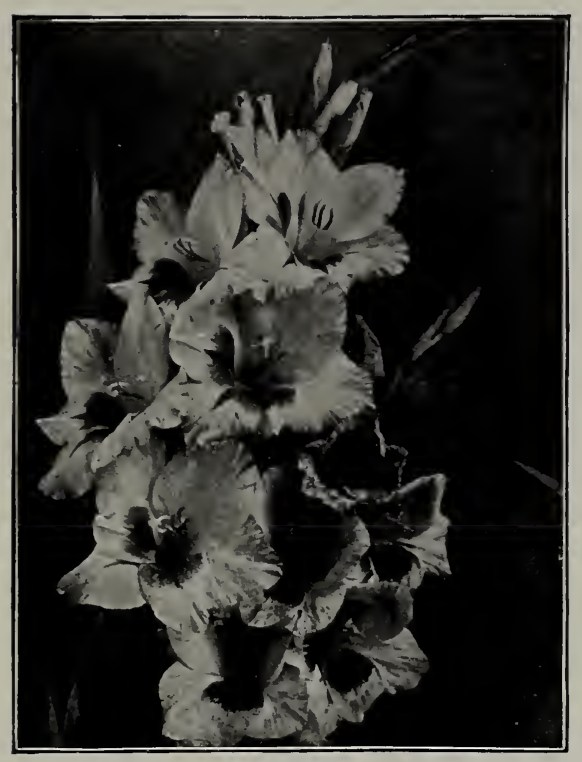

Gla diolus

\section{Gladioli}

Common Red. This is the common Gladiolus so frequently seen in our gardens; flowers borne in one-sided spikes; bright red.

Mixed Colors. Under the above heading we are selling a very fine lot of plants of our own origination from selected seed. Among them are some of the finest we have ever seen, ranging in color from almost white to nearly black.

Lemoine's Seedling. Of the seedling Gladioli grown by Mr. Lemoine, we have some ro or I 2 varieties. These varieties range in shades from white with deep velvety red throats, to deep purple with throats almost black. The characteristic feature of the Lemoine's Seedling is the deep mottling of dark color in the throat of the flower, and the plants are a little irregular in their habits of growth. Desirable.

\section{Iris}

German. This group blooms early and with wonderful combinations of coloring. Easily distinguished from other Iris by their broad, sword-like leaves. We offer eight named varieties. Likes a drier soil than the Japan.
Japan. Flowers differ from the German Iris in being broad and flat. They exhibit a wonderful variety of colors and shades. and appear later than the others. They rank among the most desirable of hardy plants; succeed best in a moist soil.

Siberian. We regard this as one of the most desirable plants for a border, or for marking lines, etc., known to us. It is very persistent, and will hold its own in blue-grass sod. Foliage long, slender and graceful; flowers borne on slender stems about 18 inches to 2 feet high, usually two or three flowers on a stem. The flowers are a deep, clear purple and very graceful. It is perfectly hardy, and we consider it one of the most desirable of the Iris family.

\section{Lilies (Lilium)}

Lilies are among the most beautiful of flowers, but they need planting on welldrained soil, and if fertilizers are used they must be well decomposed.

L. auratum. Very large, with gold band along the center of petals, much spotted with brown; very fragrant. Blooms in August.

L. lancifolium album. Same as Lilium lancifolium rubrum, with the exception that the plant is not quite so rank a grower. The flower is a pure waxy white. Perfectly hardy in this latitude.

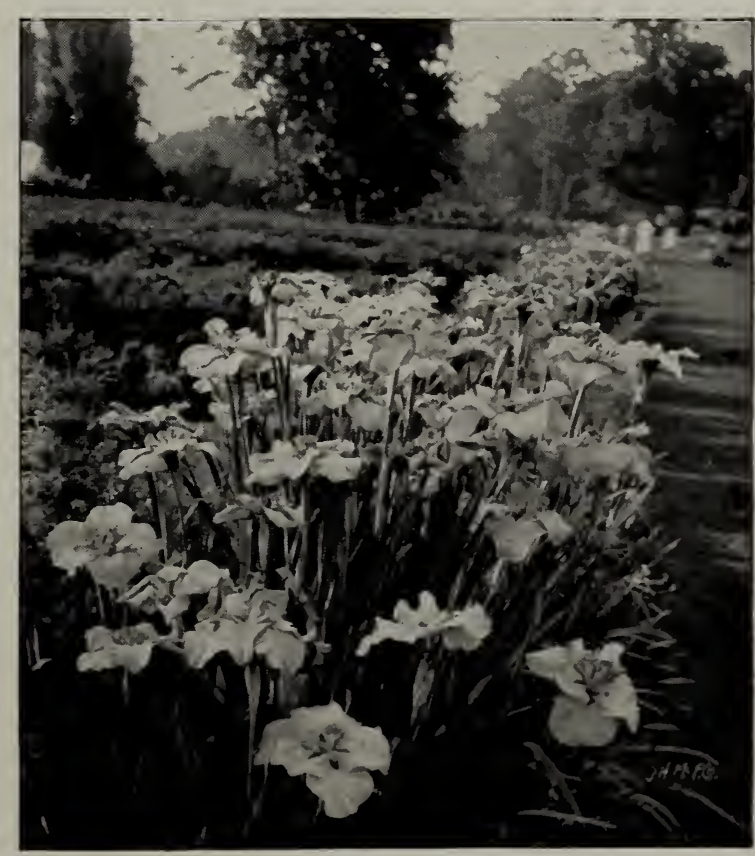

Iris $\mathrm{K} æ m p f e r i$ 


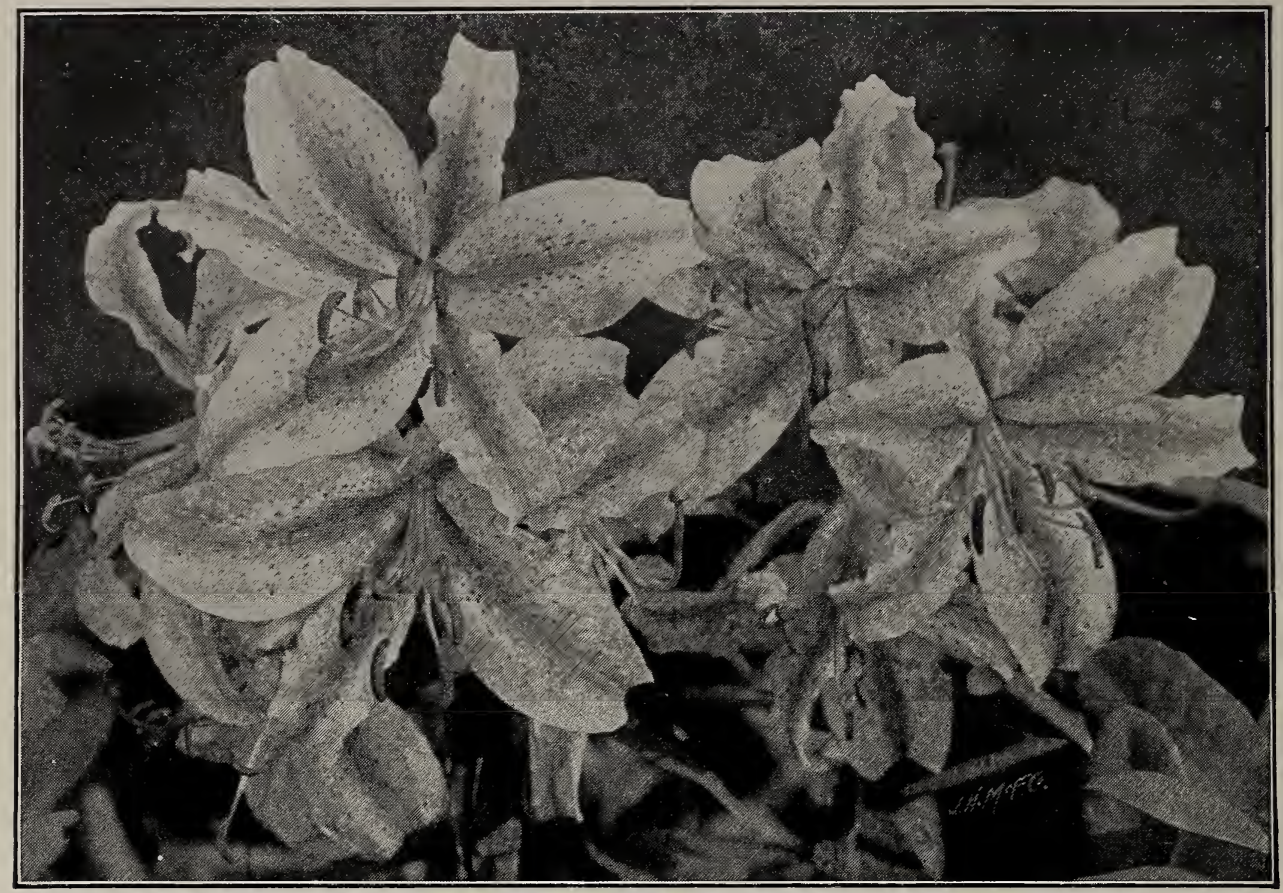

Lilium Auratum (see page 43)

\section{Lilies, continued}

Lilium lancifolium rubrum. This we think beyond question the hardiest of all of the Japanese Lilies. The plant grows to the height of about 18 to 24 inches. Foliage dark green and lanceolate, hence the name. Flowers borne in clusters of from five to twenty, pink at margin of petal, deep rose color in center, thickly dotted with brown; petals curling back like petals of the Tiger Lily. We regard it as perfectly hardy.
L. tigrinum (Tiger Lily). Very common; color orange-salmon, spotted dark brown.

\section{Corn Lily}

Foliage pale green, very long, slender and pointed. Flowers borne in clusters, and the individual flowers last but for one day. The Lily is salmon color, tinged with red. Perfectly hardy.

\section{Day Lily (Funkia alba)}

This is the common white Day Lily which we see so often in

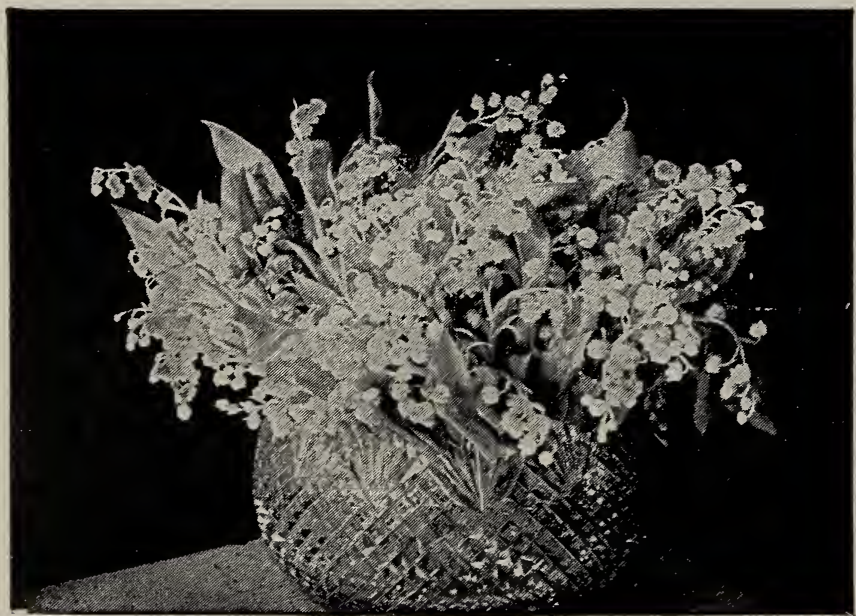

Lily-of-the-Valley house culture. The blossoms are trumpet-shaped, glossy white in color, and borne in clusters. The plant is hardy here in open ground with but little protection.

\section{Lemon Lily}

A pretty plant, with long, narrow leaves, and flower stalks 2 to 3 feet high, crowned by beautiful lemon-colored flowers, 3 to 4 in. in diameter; fragrant.

\section{Lily-of-the-Valley}

Low plant; flower-stalks about 6 inches high, with small, cup-shaped white flowers along the stalk. 


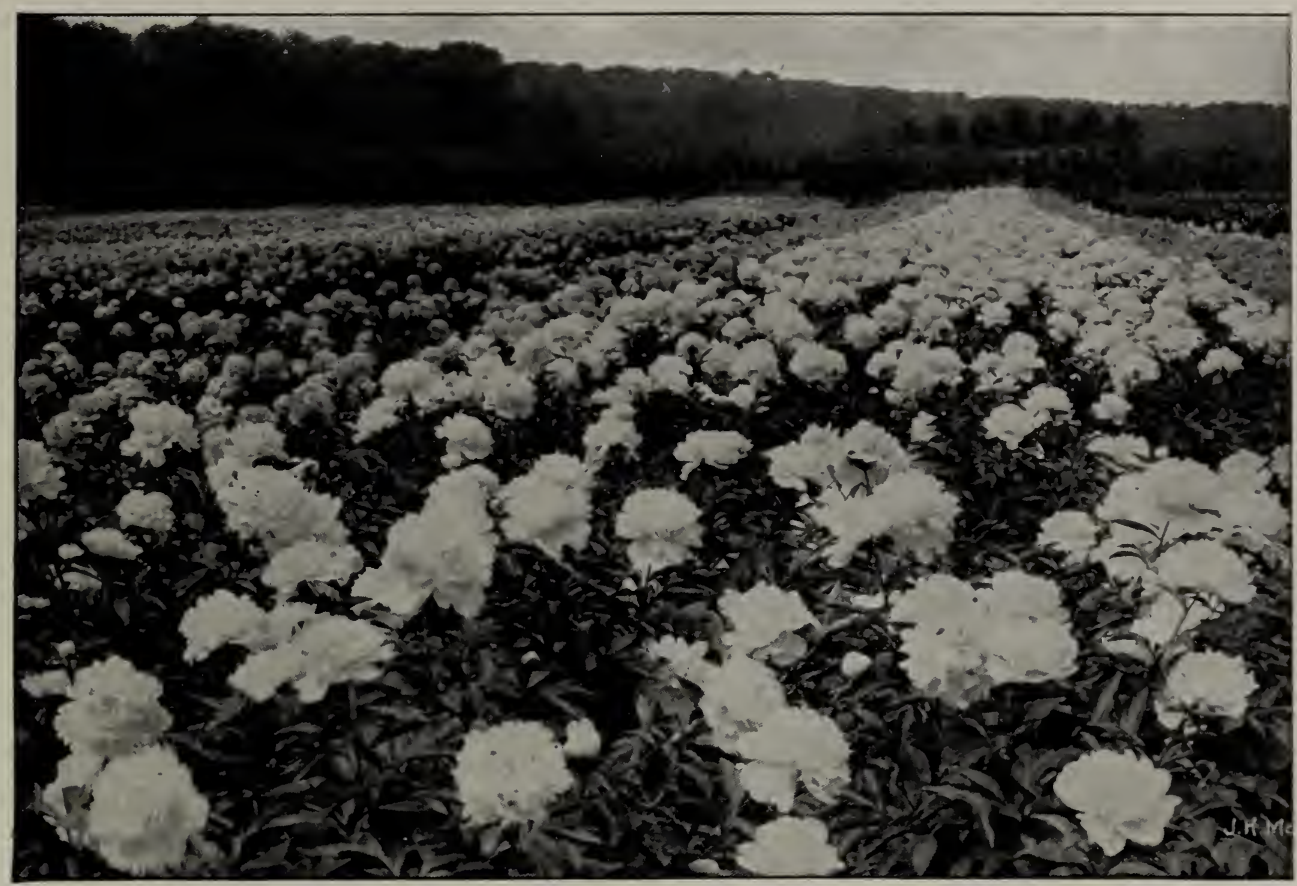

A Field of Festiva Maxima Peonies

\section{Miscellaneous}

\section{Aquilegia caerulea (Rocky Mountain Columbine)}

A fine Rocky Mountain species, with large flowers, often 4 inches across. The sepals are deep blue; petals pure white; spurs recurved. Splendid for cutting, the flowers retaining their freshness a long time.

\section{Bleeding-Heart}

A hardy perennial with heart-shaped, rose-colored flowers in drooping spikes. One of the best border plants; perfectly hardy and easily cultivated; 2 feet high. Flowers in April or May.

\section{Dahlia}

This is the well-known plant so common in all old gardens. Flowers borne on stems from 3 to 5 feet high, varying in color from white to deep red, and from single to very double.

\section{Peony}

Pink. Light fresh pink; fragrant; early.

Red. This is the common red Peony so well known that it needs no introduction. Perfectly hardy; blooms well under almost any circumstances.

White. Same as above, except in color.

Caroline Mather. Purple-crimson; very large, double and very dark.

Festiva maxima. Flowers large, creamy white, with small center of carmine; round, a strong vigorous plant bearing an abundance of flowers.

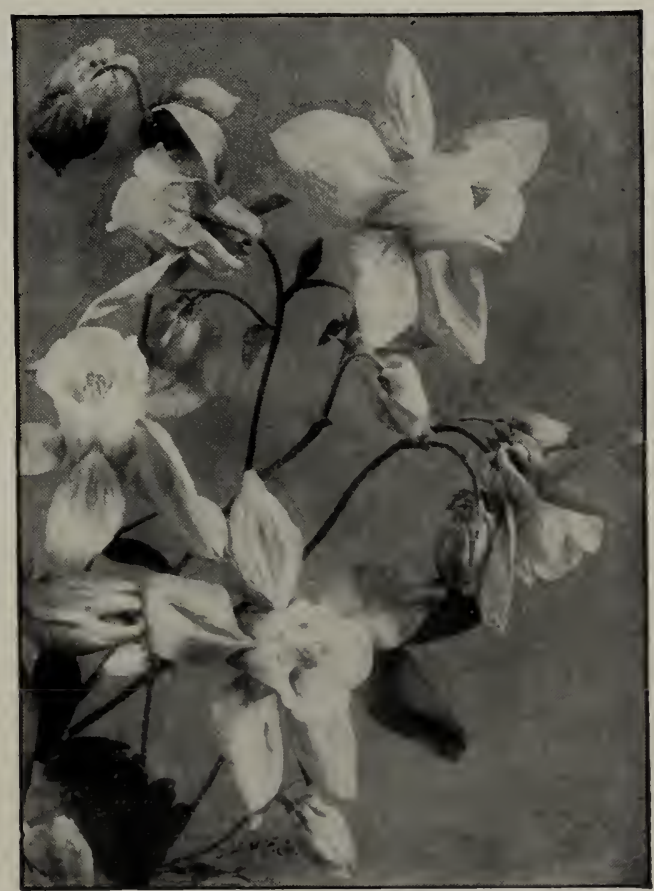

Aquilegia cærulea 


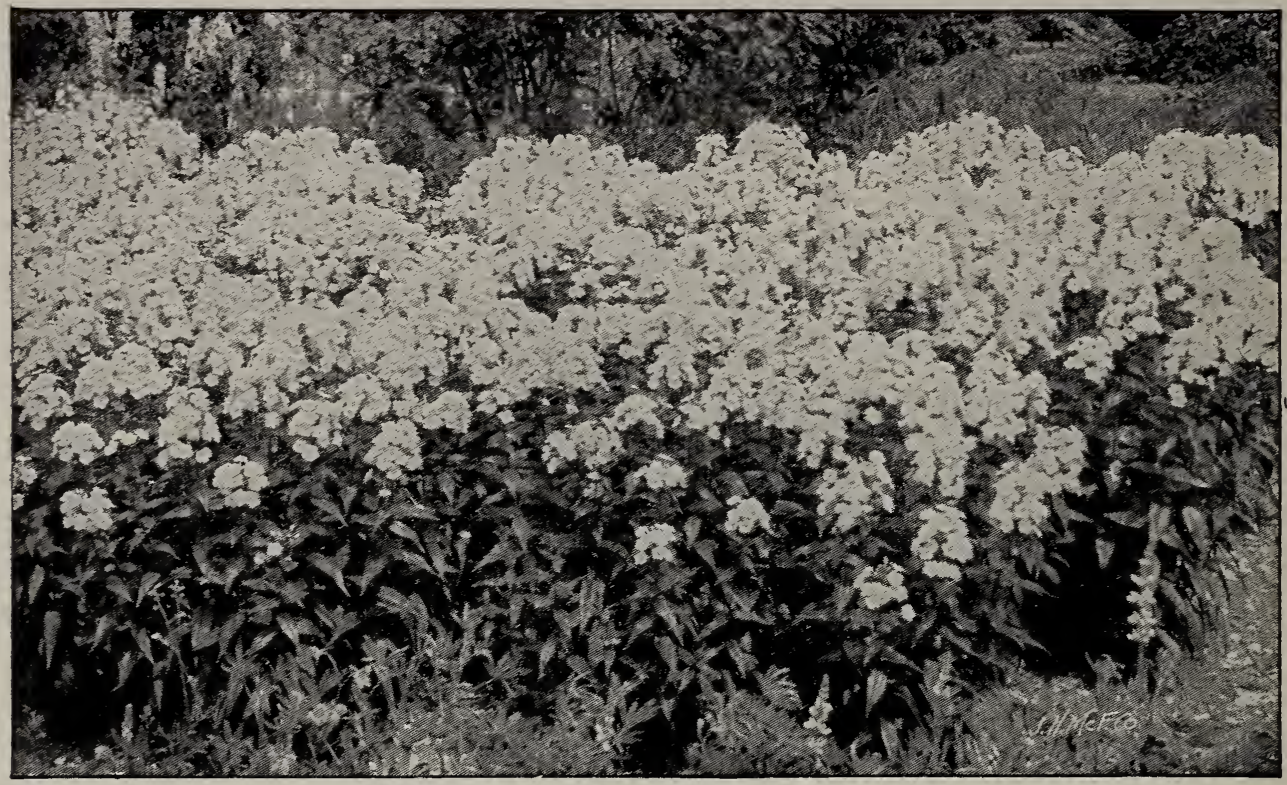

Hardy Phlox

Peony, continued

Francis Ortegal. Dark purple-crimson, very large, fine, deep, double and sweet.

Humei. Rose, full, large, late; one of the best.

La Martine. Bright red, full, good.

\section{Phlox}

This is a class of plants which are much neglected. We have them ranging in color from white to deep blue. We regard them

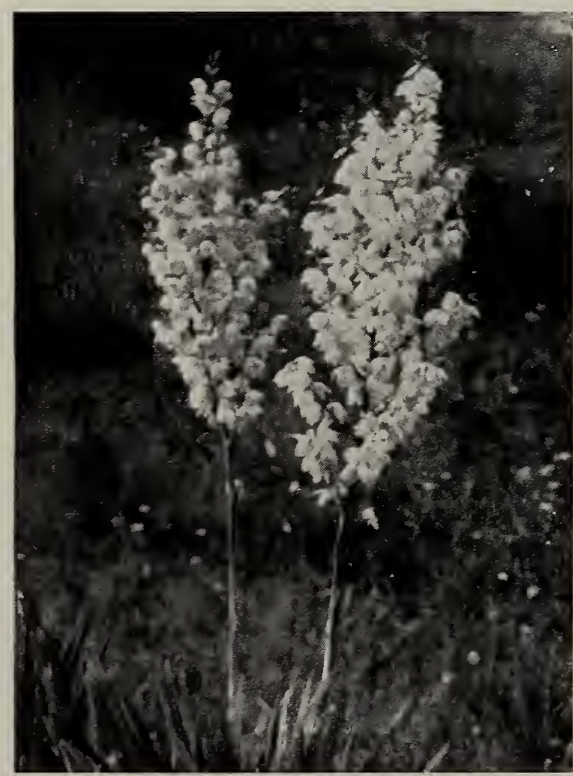

Yucca filamentosa as very desirable for border planting No perennial is more worthy of culture, more satisfactory in every situation or more effective, either as individual plants or grouped in masses.

\section{Rudbeckia laciniata fl. pl., "Golden Glow",}

A distinct, tall-growing hardy perennial, from 6 to 7 feet high. Foliage deeply cut, handsome bright green; flowers very double, rich golden yellow, 2 to 3 inches in diameter, borne on long smooth stems, forming for the tall plant a solid head of bloom. Excellent for cutting. Hardy.

\section{Vinca (Myrtle, or Periwinkle)}

A small evergreen vine, with broad leaves, and pale blue flowers which are scattered over the plant from the time the snow begins to leave until late in summer. The plant is a rank grower and is highly valued for covering mounds, graves, and so on.

\section{Yucca filamentosa}

This variety is distinguished from the other Yuccas in that it has threads or filaments along the margins of the leaves. This plant throws up flower-stalks which grow to the height of about 5 to 6 feet, branching in tree form, and when in full bloom are loaded with tulip-shaped, pendulent, white flowers. In this latitude the plant should have a light covering of straw, or some light material, to give the best results. It is better planted on rather dry land. 


\section{The Home People Who Have Known Us for the Past Twenty-eight Years}

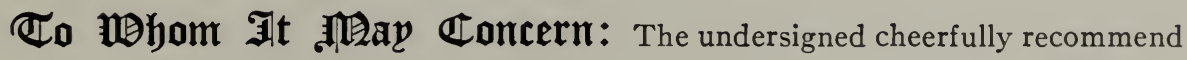
The Sherman Nursery Company, of Charles City, Iowa, to all parties desiring to plant nursery stock that is hardy and well adapted to cultivation in the great Northwest.

They are the most extensive growers of trees in the North, having in cultivation on their grounds, near the city, two million apple trees, $t$ wenty-five million evergreens, and also large quantities of small fruit, ornamental trees, vines, shrubs, etc.

We believe the parties having charge of their work to be good business men, giving careful attention to the various details of their work, and that any contracts made by them will be faithfully performed.

Hon. P. W. Burr, Ex-Judge I 2 th Judicial District, Charles City, Iowa.

Hon. H. C. Baldwin, Mayor and President of Citizens National Bank, Charles City, Iowa.

F. B. Miner, Cashier Citizens National Bank, Charles City, Iowa.

George E. May, President Commercial National Bank.

John Kuck, Harness Maker.

A. L. Dodd, Manager Charles City Electric Light Co., Charles City, Iowa.

Geo. P. Morris, Agent Wells Fargo Express Co., Charles City, Iowa.

Morton Wilbur, Cashie: Security Trust and Savings Bank.

H. M. Walleser, Cashier, First National Bank.

Frank Korinke, Agent of Illinois Central Ry. Co.

Rev. E. H. Casselman, Pastor Lutheran Church and President of Lutheran Synod, Charles City, Iowa.

W. C. Hering \& Co., Furniture Manufacturers, Charles City, Iowa.

Waller Bros., Stock Dealers and Importers, Charles City, Iowa.

Rev. T. M. Evans, District Superintendent, Cedar Rapids, Iowa.
Prof. F. E. Hirsch, President Charles City College, Charles City, Iowa.

H. A. Schlick, Music Dealer, Charles City, Iowa.

Agent Chicago, Milwaukee \& St. Paul Ry. Co. Co.

W. H. Burns, Agent American Express

Pastor of M. E. Church.

E. A. Barnes, Cashier First National Bank, Nashua, Iowa.

Hecht Bros., Charles City, Iowa.

L. H. Henry, Editor "Herald," Charles City, Iowa.

Samuel Phelps Leland, Lecturer.

V. Rev. J. J. Garland, V. F., Catholic Priest.

Rhinesmith \& Dodge, Editors Daily and Weekly Intelligencer.

Ellis \& Ellis, Attorneys at Law.

O. C. Hunter, Prop. Hildreth Hotel.

Hart-Parr Co., Manufacturers of Gas Tractors (By C. W. Hart, President).

Charles City Western Ry. Co. (By H. E. Bennett, Assistant General Manager.

J. R. Caffyn, Pastor M. E. Church.

R. J. Taylor, Agent Chicago, Milwaukee \& St. Paul Ry. Co. 


\section{Suitable Distances for Planting}

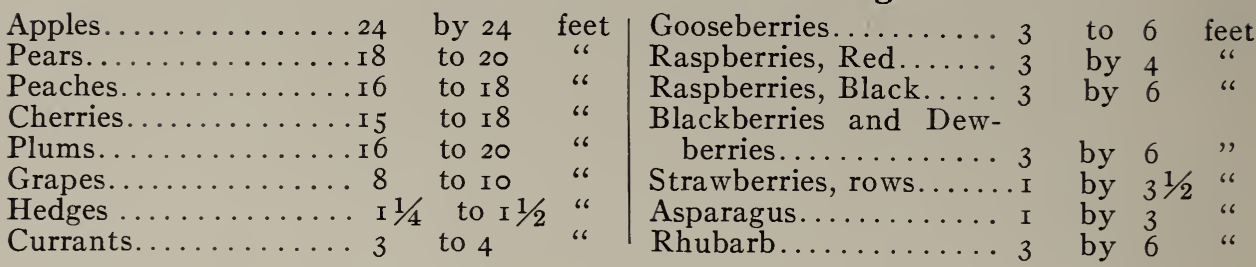

Number of Trees or Plants on an Acre

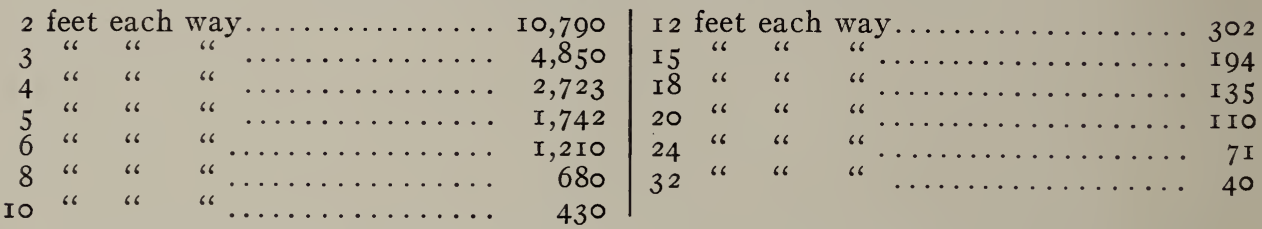

To ascertain the number of plants required to the acre at any given distance, divide the number of square feet $(43,560)$ in an acre by the number of square feet you desire to devote to each plant. For instance, in strawberries planted $1 \frac{1}{2}$ by 4 feet, each hill will occupy 6 square feet, making 7,260 plants to the acre.

\section{INDEX}

\begin{tabular}{|c|c|c|}
\hline & & \\
\hline spice, Carolina.. & Iderberr & Pears \\
\hline lowering. & lder, Box &, 46 \\
\hline & $\operatorname{lm} \ldots \ldots$ & Periwin \\
\hline mpelopsis.. & Zuonymus. . & Phlox. \\
\hline $.3-10$ & Evergreens & Pine \\
\hline . II & .28 & Plum, Flowering. \\
\hline$\cdots 45$ & & \\
\hline ..28 & Misce & \\
\hline$\cdots 42$ & $3-22$ & vet. \\
\hline$\cdots 25,26,27$ & & $.28,36$ \\
\hline$\ldots \ldots \ldots 24$ & .46 & \\
\hline & . I9 & $\mathrm{Ja}$ \\
\hline & I 6-I9 & 22 \\
\hline & & \\
\hline 25,26 & & \\
\hline & & \\
\hline & & 46 \\
\hline .45 & & . $33-37$ \\
\hline .32 & 42 & $\cdots \cdot 3^{2}$ \\
\hline & .26 & $\mathrm{Sr}$ \\
\hline$\ldots \ldots 43,44$ & .26 & \\
\hline$\ldots \ldots \ldots 33$ & $\ldots 34$ & $\ldots .36$ \\
\hline & .43 & $\cdots 36,37$ \\
\hline & & \\
\hline .26 & .24 & \\
\hline .28 & .30 & perry.....24 \\
\hline . I5, I 6,26 & & \\
\hline 26,33 & & .33 \\
\hline $.4 \mathrm{I}, 42$ & 44 & \\
\hline ntucky...27 & .26 & \\
\hline & .44 & Thorn, White.. \\
\hline & & Shade and Orna- \\
\hline .26 & & $\cdots 26-28$ \\
\hline 10 & & \\
\hline & & \\
\hline .28 & & $\ldots 28$ \\
\hline h-bush. 24,34 & & $\ldots 24$ \\
\hline 20,21 & & \\
\hline .34 & & \\
\hline & & ia Creep \\
\hline$\cdots 34$ & & \\
\hline & & \\
\hline & & \\
\hline & & W110 Ws \\
\hline$\cdot 3$ & & Wistaria \\
\hline & Peaches... & Yucca.. \\
\hline
\end{tabular}


